\title{
62. THE GEOLOGIC HISTORY OF THE MID-PACIFIC MOUNTAINS IN THE CENTRAL NORTH PACIFIC OCEAN-A SYNTHESIS OF DEEP-SEA DRILLING STUDIES ${ }^{1}$
}

\author{
Jörn Thiede, ${ }^{2}$ Walter E. Dean, ${ }^{3}$ David K. Rea, ${ }^{4}$ Tracy L. Vallier,${ }^{5}$ and Charles G. Adelseck ${ }^{6}$
}

\begin{abstract}
The Mid-Pacific Mountains constitute one of the largest aseismic rises in the central North Pacific Ocean. They have been generated by mid-plate volcanic events prior to Barremian time, but their volcanic activity continued through the remainder of the Cretaceous. Evidence of the latest stages of this volcanism are the trachytic ashes included in mid-and Late Cretaceous sediments and the presence of guyots atop the main volcanic pedestal.

The thermal and volcanic history of the oldest part of the Pacific Plate and its plate tectonic movements since Cretaceous time have led to considerable horizontal and vertical movements of the Mid-Pacific Mountains. Reconstruction of their subsidence and evidence from the sediments from Site 463 suggest that they once, in Cretaceous time, constituted large, tropical volcanic islands which were covered by vegetation and which shed their erosional debris over the adjacent island slopes. Neritic fossils in Maastrichtian sediments document the presence of shoal areas until the end of the Mesozoic. Since then they have subsided to their present water depth. The horizontal movements of the Pacific Plate have carried the Mid-Pacific Mountains from a position well south of the Cretaceous equator to their present position under the unproductive surface waters of the subtropical central North Pacific Ocean. Site 463, on the western Mid-Pacific Mountains, probably crossed the equator in Maastrichtian time.

Shallow-water-derived calcareous fossils are incorporated into the pelagic sediments covering the Mid-Pacific Mountains. They have been displaced from their source areas along the flanks of seamounts over the adjacent regions during times of low sea-level stands. Debris of land plants in Aptian sediments documents the presence of emergent volcanoes during that time.

The pelagic sediments penetrated at Site 463 consist largely of a sequence of Cretaceous chalks, limestones, and cherts which accumulated fast and which document the presence of highly productive surface water masses around the former volcanic islands and above the shoals. The development of oxygen-deficient depositional environments and the lack of evidence for intensive reworking suggest at the same time very sluggish water movements in the meso- and bathypelagic environment during Early and mid-Cretaceous times.

The Cenozoic calcareous oozes, on the other hand, are very condensed. They are interrupted in several places by hiatuses, and despite their position well above the CCD they show effects of dissolution and poor preservation of the calcareous faunas and floras. The frequency of reworked pelagic material together with the hiatuses indicate episodes of intensive renewal of the meso- and bathypelagic water masses which generated intensive sea-floor erosion and which were probably triggered by the climatic deterioration in the polar regions.
\end{abstract}

\section{INTRODUCTION}

\section{Morphology, Age, Plate-Tectonic Setting, and Previous Studies}

The Mid-Pacific Mountains, located south of the Hawaiian Ridge, constitute a prominent structural high on top of Mesozoic, probably Jurassic and Lower Cretaceous crust (Larson, 1976) of the central north Pacific Ocean. It is one of a series of submarine oceanic plateaus of volcanic origin that is typical of oceanic crust of Mesozoic age (Schlanger et al., 1981). These features rise as many as several kilometers above the surrounding deep ocean floor, and are capped by very thick, mostly calcareous sedimentary sequences. Many oceanic plateaus have been investigated by the Deep Sea Drilling Project, because of their peculiar structural configurations, and their volcanic rocks and sedimentary sequences, which generally are different from those

\footnotetext{
1 Initial Reports of the Deep Sea Drilling Project, Volume 62.

2 Department of Geology, University of Oslo, Norway.

3 U.S. Geological Survey, Denver, Colorado.

4 Department of Atmospheric and Oceanic Science, University of Michigan, Ann Arbor, Michigan.

5 U.S. Geological Survey, Menlo Park, California.

6 Deep Sea Drilling Project, Scripps Institution of Oceanography, La Jolla, California.
}

of the surrounding ocean floor; Magellan Rise, Shatsky Rise, Hess Rise, Manihiki Rise, Tuamotu Plateau, and Ontong-Java Plateau are the best-known examples of oceanic plateaus in the Pacific Ocean. Most of these western Pacific oceanic plateaus are known to have a crust and early sedimentary sequence of late Mesozoic age, and to have undergone considerable subsidence from early subaerial positions to their present water depths. The sediments which accumulated after cessation of the pedestal-building volcanic activity record not only the effects of horizontal plate-tectonic movements (Lancelot, 1978), but also the effects of vertical subsidence caused by cooling of the underlying oceanic crust. The subsidence histories might be much more complicated than that of normal oceanic crust, however, because of the thermal effects of volcanic events associated with these large rises (Schlanger et al., 1981). In general, the depositional environments on top of these rises have been above the CCD since their early origins in Mesozoic time. The depositional environments at any one locale change with time and, during subsidence, the sediments in general document crossing through the shallow photic zone, with neritic faunas, into meso- and bathypelagic water depths. Therefore, the sediments consist largely of calcareous sequences, in 
places interrupted by chert and volcanic-ash layers (or their alteration products) of modest thicknesses.

The Mid-Pacific Mountains constitute one of the largest oceanic plateaus in the central western Pacific Ocean (Fig. 1). This plateau is on Mesozoic oceanic crust that was perturbed by dramatic volcanic events in middle and Late Cretaceous time (Schlanger et al., 1981), which led to extrusion of basaltic lava and deposition of volcanic ash over wide areas, generating a bulge-shaped region of the central Pacific Ocean floor up to $2 \mathrm{~km}$ shallower than the surrounding ocean floor (referred to as Darwin Rise by Menard, 1964). The age of the oldest sediments recovered from Site 463 suggests that this volcanic evolution started much earlier, possibly in Late Jurassic times. It can be assumed that these volcanic events (Vallier and Rea, 1980) considerably disturbed the regular subsidence of this part of the Pacific Plate.

The Mid-Pacific Mountains consist of three distinct segments (Fig. 2). The eastern and western segments strike east-northeast, more or less parallel to large central Pacific fracture zones such as the Mendocino Fracture Zone, whereas the connecting segment strikes northwest-southeast. This distinct subdivision into three units and their structural differences have given rise to speculations about the origin of the volcanic edifices under the Mid-Pacific Mountains, ranging from extinct spreading centers and triple junctions to segments of transform faults and mid-plate volcanism (Larson, 1976; Winterer, 1976; Watts et al., 1980). The age of volcanic rocks underlying the calcareous sediments that cap the Mid-Pacific Mountains remains mostly unknown because of the sparse samples. The oldest sediments at pre-Leg 62 DSDP sites were of middle or early

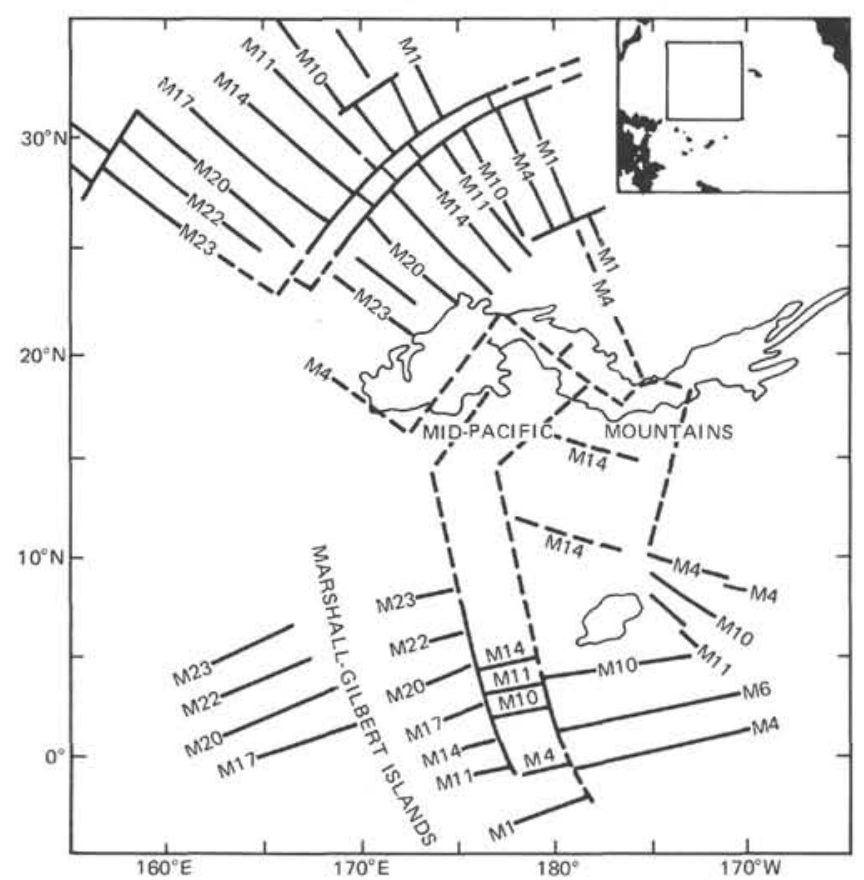

Figure 1. Present-day magnetic-lineation and fracture-zone patterns in the western central Pacific Ocean (after Larson, 1976).
Late Cretaceous age, suggesting a minimum age of the main volcanic events (Winterer, Ewing, et al., 1973) for the eastern part of the Mid-Pacific Mountains. However, the magnetic anomalies (Fig. 1) which have been mapped around the Mid-Pacific Mountains (Hilde et al., 1976; Larson, 1976) range from M4 to M25, corresponding to a time span of approximately 120 to 153 m.y. ago. Furthermore, the early plate-tectonic evolution of this part of the Pacific Plate has not yet been resolved in sufficient detail to understand the origin of the aseismic rises in this area (Fischer et al., 1970). Attempts to reconstruct the middle and late Mesozoic plate configurations (Hilde et al., 1976); Larson, 1976) suggest the existence of three major plates in Early Jurassic times (Phoenix, Kula, and Farallon), which now have largely been consumed by subduction. The Pacific Plate, which was originally surrounded by spreading centers (Hilde et al., 1976), began its history approximately 185 m.y. ago close to where the pre-existing three plates joined at a triple junction. Since then it has grown to the largest entirely oceanic plate of our globe.

The Mid-Pacific Mountains, located close to the oldest part of the Pacific Plate, have been recognized as a structural unit, at first because of their elevation above the sea floor of the surrounding ocean basins (Hamilton, 1956), and later because of the successful sampling of volcanic (basaltic) rocks and shallow-water-derived fossil assemblages from the tops of guyots which tower above the main platform that lies at approximately 3.5 km water depth (Hamilton, 1956; Lonsdale et al., 1972; Matthews et al., 1974). Hamilton (1956) gave the first comprehensive, and in part very picturesque description of the morphology and geology of the Mid-Pacific Mountains (Fig. 3). Prior to Leg 62, the Deep Sea Drilling Project had drilled the Mid-Pacific Mountains at three sites during three cruises (Legs 6, 17, and 32), which probed the Mesozoic and Cenozoic sedimentary sequences in the eastern segment (Table 1; Fig. 4). The coring records (Fig. 5) of Site 44 (Heezen, Fischer, et al., 1971), Site 171 (Winterer, Ewing, et al., 1973), and Site 313 (Larson, Moberly, et al., 1975) added a new, but somewhat spotty dimension to our understanding of the geologic history of the Mid-Pacific Mountains (Lancelot and Larson, 1975; Moberly and Larson, 1975).

\section{Objectives of DSDP Leg 62 on the Mid-Pacific Mountains}

Because the eastern segment of the Mid-Pacific Mountains had been drilled during previous DSDP legs in the central Pacific, we planned to probe the western segment. The primary objective of Site 463 was to core the lower Tertiary and upper Mesozoic sections as completely as possible, both for biostratigraphic and paleoceanographic interpretations, and to core and sample the underlying basement. The age, nature, and origin of the probable volcanic edifice under the western MidPacific Mountains are disputed, and the feature's structural relationship to the ancestral Pacific and Farallon Plates (Larson, 1976) of the Mesozoic Pacific Ocean is unclear. Magnetic anomalies M22 and M20, which abut the western segment of the Mid-Pacific Mountains north- 


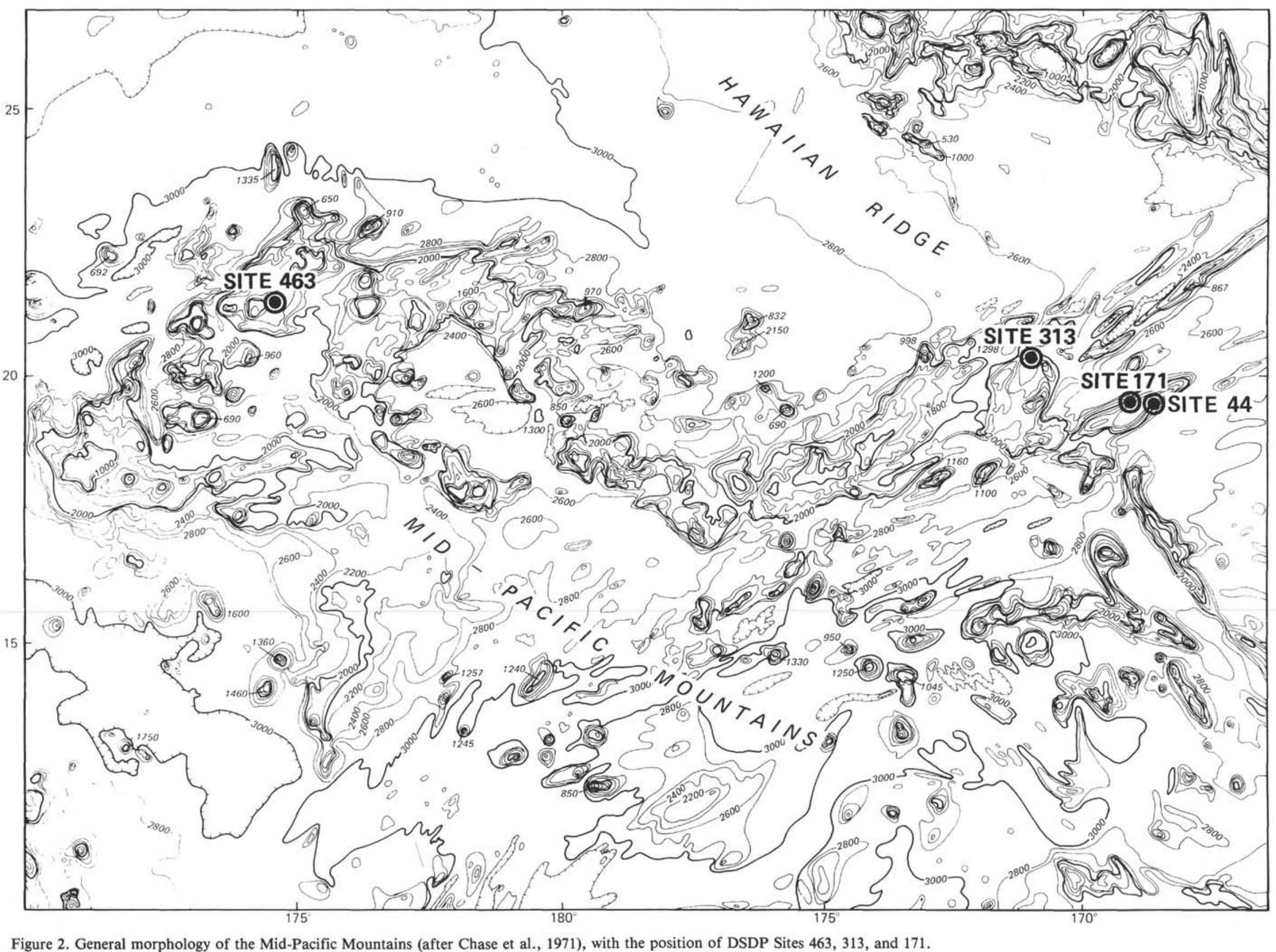

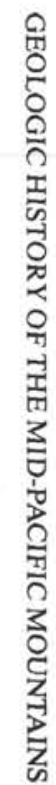




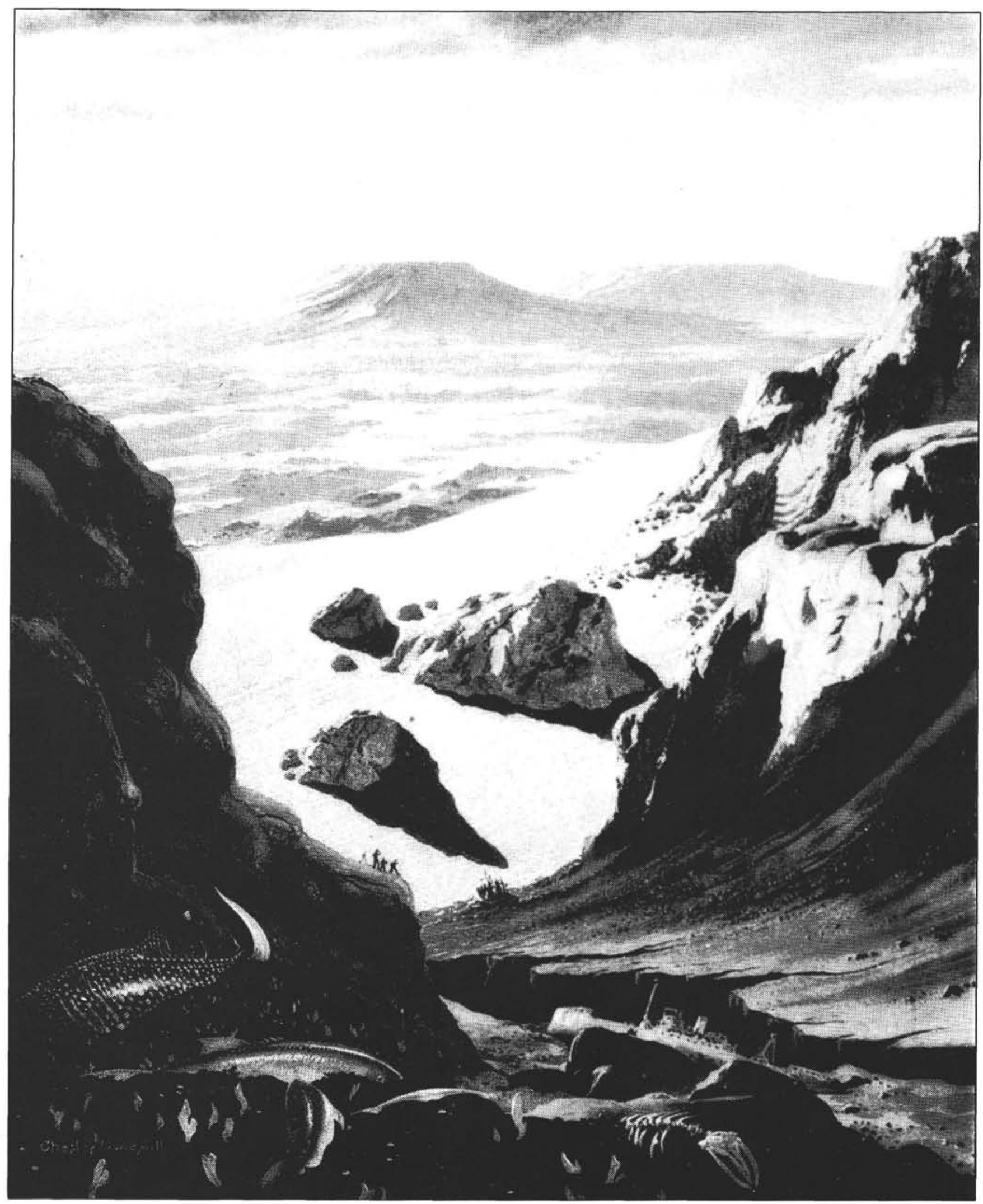

Figure 3. Pictorial illustration of the submarine landscape of the Mid-Pacific Mountains, southwest of the Hawaiian chain of islands in the central subtropical Pacific Ocean (from Hamilton, 1956). 
Table 1. Locations of DSDP sites in the Mid-Pacific Mountains (data from site reports).

\begin{tabular}{|c|c|c|c|c|c|c|c|}
\hline Leg & Site & Latitude & Longitude & $\begin{array}{c}\text { Water } \\
\text { Depth } \\
\text { (m) }\end{array}$ & $\begin{array}{l}\text { Age of oldest } \\
\text { Sediment }\end{array}$ & $\begin{array}{l}\text { Depth of } \\
\text { Oldest } \\
\text { Sediment } \\
\text { (m sub- } \\
\text { bottom) }\end{array}$ & Basement \\
\hline 6 & 44 & $19^{\circ} 18$ & $169^{\circ} 00.9^{\prime}$ & 1478 & Mic & 76 & Not reached \\
\hline 17 & 171 & $19^{\circ} 07.9^{\prime} \mathrm{N}$ & $169^{\circ} 27.6^{\prime} \mathrm{W}$ & 2290 & Cenomanian(?) & 464 & Extrusive basal \\
\hline 32 & 313 & $20^{\circ} 10.52^{\prime} \mathrm{N}$ & $170^{\circ} 57.15^{\prime} \mathrm{W}$ & 3484 & Campanian & 594 & Altered basalt \\
\hline 62 & 463 & $21^{\circ} 21.01^{\prime} \mathrm{N}$ & $174^{\circ} 40.07^{\prime} \mathrm{E}$ & 2525 & Barremian & 823 & Not reached \\
\hline
\end{tabular}

west of the site location (Fig. 1), suggest that the floor of the adjacent deep northwest Pacific Basin is 140 to 150 m.y. old.

The proposed site was located on a relatively flat part of the western Mid-Pacific Mountains (Fig. 6) where a thick sedimentary sequence covers a hummocky basement with pinnacles of probable volcanic origin which occasionally pierce the sediments and protrude up to several hundred meters above the sediment surface. It was not clear what rocks (basalt or limestone) compose the deepest and relatively flat reflector that abuts these pinnacles. The main reflector, approximately in the middle of the sedimentary sequence, was believed to be Eocene chert, which apparently covered an upper Mesozoic and lower Tertiary chalk and limestone sequence and which in turn was overlain by seismically transparent Tertiary and Quaternary nannofossil ooze. Similar layered sedimentary sequences had been observed on the eastern segment of the Mid-Pacific Mountains (Larson et al., 1975), where this reflector corresponds to the

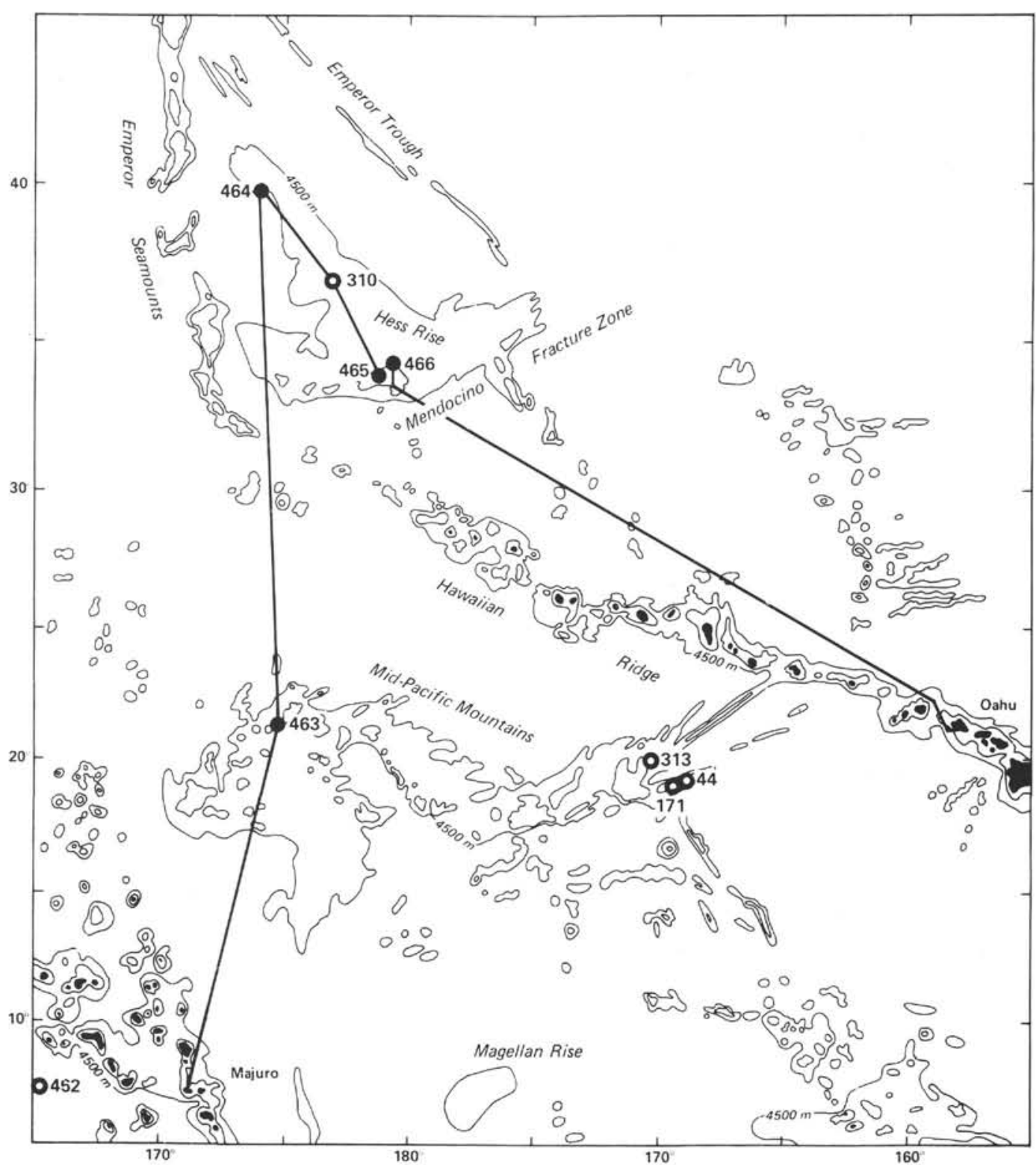

Figure 4. Locations of deep-sea drill sites on the Mid-Pacific Mountains and on Hess Rise. Leg 62 drill sites are connected by a generalized track line. 

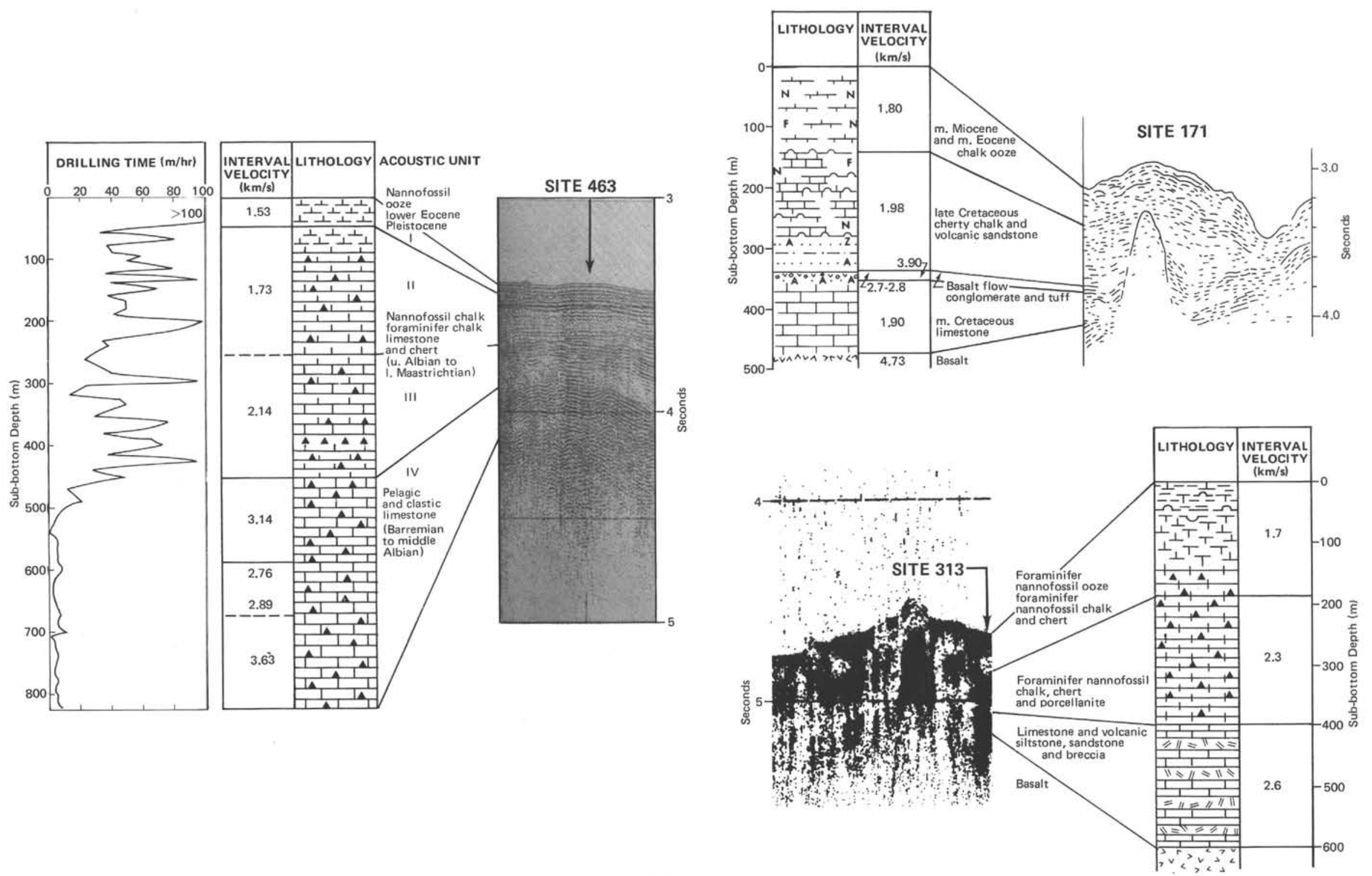

Figure 5. Coring records of DSDP Sites 171, 313, and 463 on the Mid-Pacific Mountains (from site reports). 


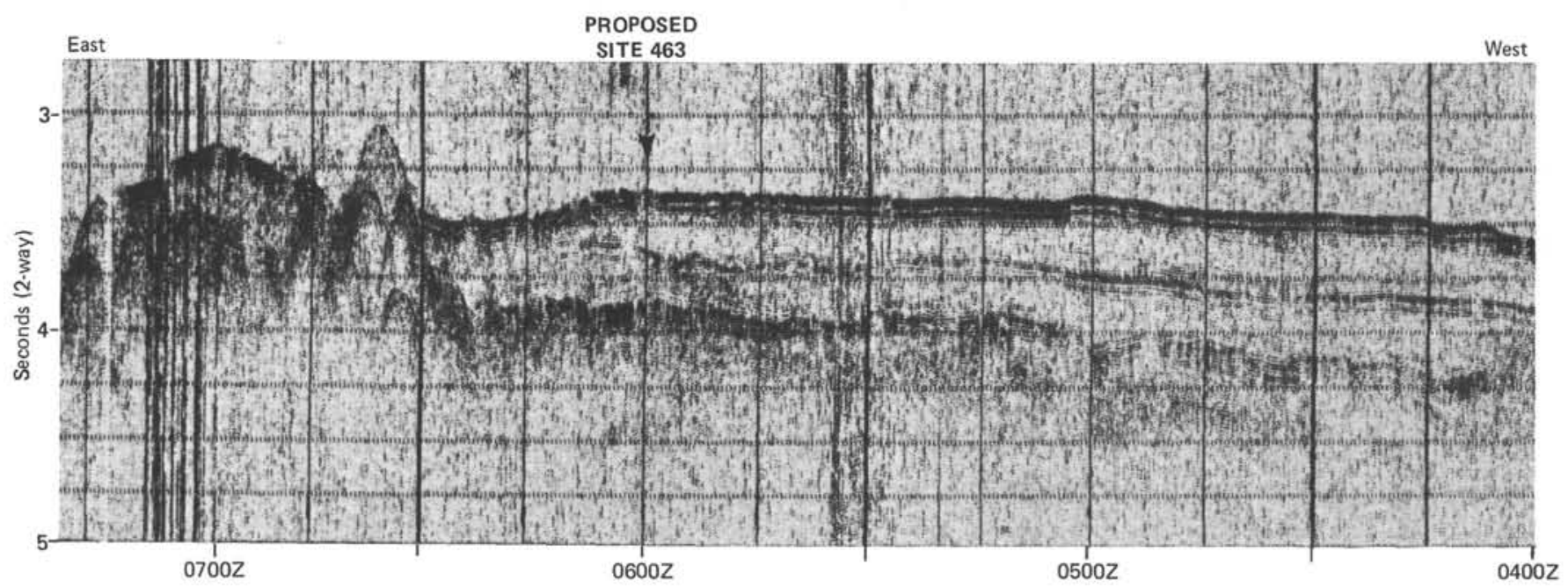

Figure 6. Five-second seismic reflection profile of Mahi Leg 5, 9 December 1970, with proposed location of Site 463 . Speed 10.6 knots.

transitional layers of Eocene and Maastrichtian chertrich chalks which are separated by an important hiatus (Larson, Moberly, et al., 1975).

\section{Purpose}

In this paper we interpret the drilling results at Site 463 in the context of the geologic evolution of the MidPacific Mountains as interpreted from seismic studies, from studies of the dredged samples of basaltic and sedimentary rocks, and from the drilling results at DSDP sites on the eastern segment. The available data from Hole 463 give us an opportunity to describe the composition of the more than 800 -meter-thick sedimentary sequence and the timing and kinds of major changes in the depositional environments. The continuity of the sedimentary sequences at all three Mid-Pacific Mountain sites, where comprehensive coring records are available (Sites 171, 313, and 463), however, are interrupted by long-lasting hiatuses (Fig. 7). We found that parts of the penetrated sedimentary columns are composed of sediments that contain a major portion of reworked material. This reworked sediment has undergone vertical and(or) horizontal transport and the source area or areas are not accurately known. Our understanding of the evolution of the depositional environments will therefore remain fragmentary because of the complexity of the sediment record.

Our interpretation of depositional environments is dependent on understandings of several interrelated factors, including (1) the frequency of volcanic events leading to the construction of the Mid-Pacific Mountains, (2) paleogeography and paleobathymetry, (3) processes that control fluxes of sediment components, (4) processes that remoblize parts of the sediment cover, and (5) diagenesis.

\section{MAIN RESULTS OF PRE-LEG 62 INVESTIGATIONS OF THE MID-PACIFIC MOUNTAINS}

The geological investigations prior to deep-sea drilling had provided a thorough morphologic description
(Hamilton, 1956) and had shown that the Mid-Pacific Mountains are a volcanic feature, because volcanic rocks had been dredged from the sides and tops of some guyots. Early investigators also had documented that the guyots in late Mesozoic time (Cenomanian to Maastrichtian) must have been situated very close to sea level, because of the numerous observations of neritic fossils in Upper Cretaceous sediments (Hamilton, 1956; Lonsdale et al., 1972; Matthews et al., 1974), whereas younger sediments were largely composed of calcareous oozes and chalks deposited in a pelagic environment. Deep-sea drill sites have added considerably to this body of data because of the precise location of the samples and because of the undisturbed stratigraphic sequences which have been obtained, allowing determination of the timing of the geologic events in the evolution of the Mid-Pacific Mountains.

The most important results were obtained at DSDP Sites 171 and 313, on the eastern segment of the MidPacific Mountains, which penetrated and sampled largely calcareous Cenozoic and upper Mesozoic sedimentary sequences down to igneous rocks believed to belong to the volcanic basement. Basalts at Site 171 are interlayered with Cenomanian shallow-water limestone and conglomerate composed of limestone and volcanic rocks. The basaltic rocks are highly altered tholeiite (Natland, 1976); highly vesicular basalt pebbles and cobbles in the conglomeratic layers are rounded and deeply weathered. The fine-grained basalts recovered below Campanian volcanic sandstone and limestone at Site 313 have an alkalic composition; they therefore are not part of normal ridge-generated oceanic crust, but probably formed later, during the growth of seamounts. Because of the interlayering of the volcanic rocks and sediments (Site 171) and of rapid changes of drilling rates which suggested the presence of sedimentary layers under the basalt of Site 313, it was questioned whether the pedestal-forming volcanic basement really had been reached. In general, all samples of volcanic rocks collected on the Mid-Pacific Mountains were obtained from guyots which obviously represent the latest stage 


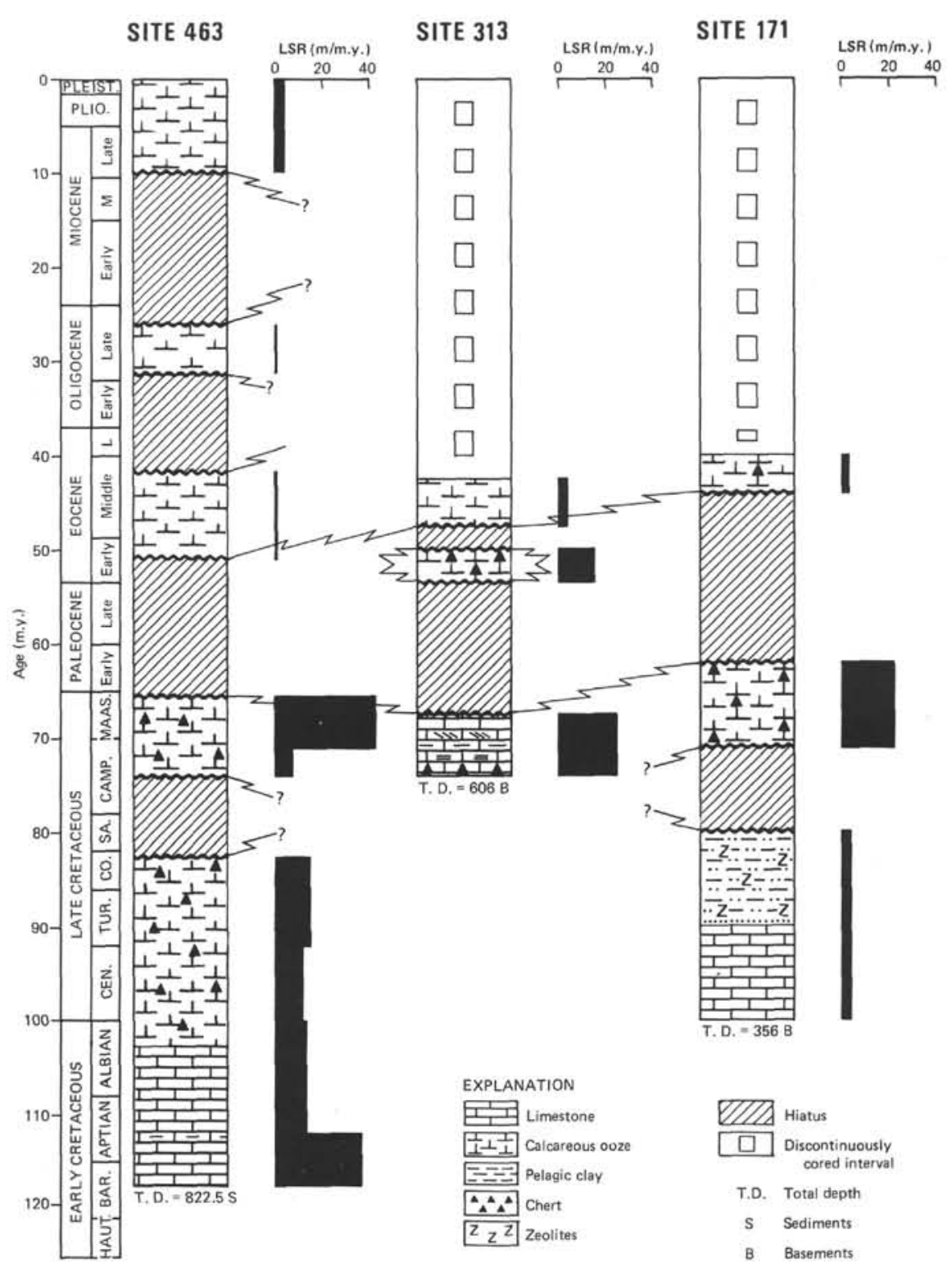

Figure 7. Distribution of hiatuses and linear sedimentation rates in the sedimentary sequences at Sites 171,313 , and 463 .

in the evolution of volcanic events which first led to the formation of two platforms, now at different depths (see below), that bear the guyots. The nature and stage of preservation of the Site 171 basalt samples (Bass et al., 1973) suggest that Horizon Guyot was at least partly emergent during mid-Cretaceous time. This interpretation is supported by neritic calcareous fossils in the conglomerate and limestone beds penetrated in the lower part of Site 171, which is well below the shallowest level of Horizon Guyot, but more than $1 \mathrm{~km}$ above Site 313 . The interpretation also is supported by land-plant remains in the volcanic sandstones of late Turonian and possibly Coniacian age at Site 171 .

The Mesozoic sedimentary sections of both drill sites in the eastern Mid-Pacific Mountains are of different thickness and composition, although both contain volcanogenic as well as calcareous deposits. Site 171 penetrated a nearly complete Upper Cretaceous section with thick Maastrichtian and upper Campanian sequences; in contrast, the interval of Santonian to Cenomanian age was thinner and apparently less complete. The oldest calcareous sediments found in the conglomerate units of Site 171 are clearly indicative of a source area in very shallow water, because they contain a rather rich assemblage of neritic fossils (for example mollusks and the remains of algae). The sediments also were subjected to subaerial dissolution and cementation processes. The sedimentary sequence at Site 313 was deposited also during Late Cretaceous and Cenozoic time, but it does not contain clear indicators of nearby neritic environments. The Mesozoic sections of both sites also contain chert and variously preserved opaline fossils.

The Cenozoic sediments from all three sites on the eastern Mid-Pacific Mountains consist of calcareous oozes and chalks, with some chert in the Eocene intervals. The few cores recovered at Site 44 contain lower 
Oligocene, and upper and middle Eocene foraminifer nannofossil ooze. The spot-cored Cenozoic section of Site 171 comprises Quaternary, middle and lower Miocene, Oligocene, and middle Eocene sediments. The microfossil assemblages from several intervals are highly mixed with reworked material, in part originating from horizons that were not recovered in cores from this bore hole. The sparse Cenozoic cores of Site 313 are in general similar to the record of Site 171, but many of the calcareous faunas and floras are less well preserved because of the deeper waters of the site. In places, the Cenozoic sections from all three sites contain opaline fossils, mostly radiolarians.

\section{SEISMIC DATA: MORPHOLOGY OF BASEMENT AND SEDIMENT COVER}

The western segment of the Mid-Pacific Mountains has not been visited frequently by research vessels. The coverage of seismic lines i.. the vicinity of Site 463 is accordingly sparse. However, the seismic-reflection profiles obtained during approach to and departure from Site 463 offer some insight into the nature of basement and sediment cover (Figs. 8-10). The Mid-Pacific Mountains north of the central Pacific Basin exhibit two broad levels of topography, a deeper one near 4100 meters and a higher one near 2600 meters. The southern edge of the Mid-Pacific Mountains along the Glomar Challenger track line is marked by a large guyot (Figure 8 ) which rises within 1.75 seconds $(1300 \mathrm{~m})$ of the surface; it separates the lower plateau level from the central basin floor. The sedimentary cover of the lower plateau exhibits alternating acoustically reflective and transparent intervals and overlies an acoustic basement of unknown composition (Figs. 9 and 10). In places, the sediments are cut by closely spaced, near-vertical normal faults which affect parts of the section by as much as 100 meters. The youngest sediments apparently blanket the topographic offsets of the faults (e.g., Fig. 9, $1930 \mathrm{Z}, 2145 \mathrm{Z}$, and 2300Z). The portion of the MidPacific Mountains belonging to the upper plateau (which begins at $0800 \mathrm{Z}$ on Fig. 10) displays a more-hummocky topography with numerous hyperbolic echoes, after which a sedimentary basin extends toward the northern edge of the Mid-Pacific Mountains.

\section{EVIDENCE OF VOLCANIC EVENTS IN THE MID-PACIFIC MOUNTAINS REGION}

\section{Volcanic Structure and Igneous Rocks}

Seamounts and guyots of the Mid-Pacific Mountains cap a platform or pedestal that rises above the surrounding sea floor. The origin of the platform is not known, but dredged samples from a deep ridge on the platform are basalt (Heezen et al., 1973), which indicates that the raised part of the ocean floor probably is related to thickening by volcanic processes.

Information on the nature of igneous rocks and volcanic structure of the Mid-Pacific Mountains is derived mainly from dredge hauls of guyots and seamounts and from deep-sea drilling (Hamilton, 1956; Heezen et al., 1973; Bass et al., 1973; Marshall, 1975; Natland, 1976).
The pioneer work by Hamilton (1956) provided preliminary data on both the ages and compositions of the guyots that, in a broad sense, were sufficient to deduce the main geological aspects of the Mid-Pacific Mountains. He found that the guyots were as old as Aptian to Cenomanian and concluded that they were wave-eroded volcanoes composed of basaltic rocks. Later interpretations have not changed significantly (cf., Lonsdale et al., 1972; Natland, 1976).

A compilation of data on the igneous rocks from the Mid-Pacific Mountains region shows the range of compositions (Table 2). All published chemical analyses (Bass et al., 1973; Marshall, 1975; Natland, 1976) indicate the alkalic affinities of the rocks; which range from silica-poor alkali basalt to silica-rich trachyte. From our limited data, it can be concluded that the guyots and seamounts are composed primarily of alkali basalt and the differentiates of alkali-basalt magma. The volume of volcanic outpourings in the mid-Cretaceous was large, and the Mid-Pacific Mountains, as an igneous province, may constitute one of the largest alkalic-rock provinces in the world oceans.

Hole 463 did not reach the volcanic basement. However, the clastic limestones of the lowermost lithologic unit contain some rounded chips of basalt. They probably are from outcrops of the volcanic-island pedestal that was itself surrounded by shallow-water depositional environments and was the source area of the shallow-water-derived carbonates.

\section{Volcanogenic Sediments}

The magmatic history of the central Pacific did not end with the construction of the guyots and seamounts. Volcanogenic materials in the form of volcanic glass, feldspars, opaque minerals, and secondary smectite and zeolites occur through most of the sedimentary section encountered in the western Mid-Pacific Mountains. Several chapters in this volume contain information pertaining to the volcanic sedimentary component, including the chapters describing the mineralogy of Site 463 sediments (Nagel and Schumann; Rateev and others; Vallier and Jefferson), and the chapter documenting the mass-accumulation rate (MAR) of the inorganic fraction of the sediments (Rea and Janecek). These data (Fig. 11), along with the lithologic descriptions in the site report, form the basis for the following discussion.

Minor amounts of diffuse volcanogenic material occur in the Cenozoic sediments (Cores 1-7) of the western Mid-Pacific Mountains. Moderate amounts occur as a diffuse component in Maastrichtian carbonate oozes (Cores 8-20). In the lower Maastrichtian sediments, smectites dominate the clay-mineral assemblage, and the MAR of the non-biogenic fraction exceeds 0.3 $\mathrm{g} \cdot \mathrm{cm}^{-2} \cdot 10^{-3} \mathrm{yr}^{-1}$ (Fig. 11). From the Campanian through the middle Albian (Cores 21-54), which corresponds to the lower portion of sedimentary Unit I and upper portion of Unit II, low amounts of volcanic material occur in the form of minor smectite in the claymineral fraction. In the lower Albian to upper Aptian, both the abundance of smectites and the MAR of the inorganic fraction increase. The volcanogenic material re- 


\section{J. THIEDE ET AL.}
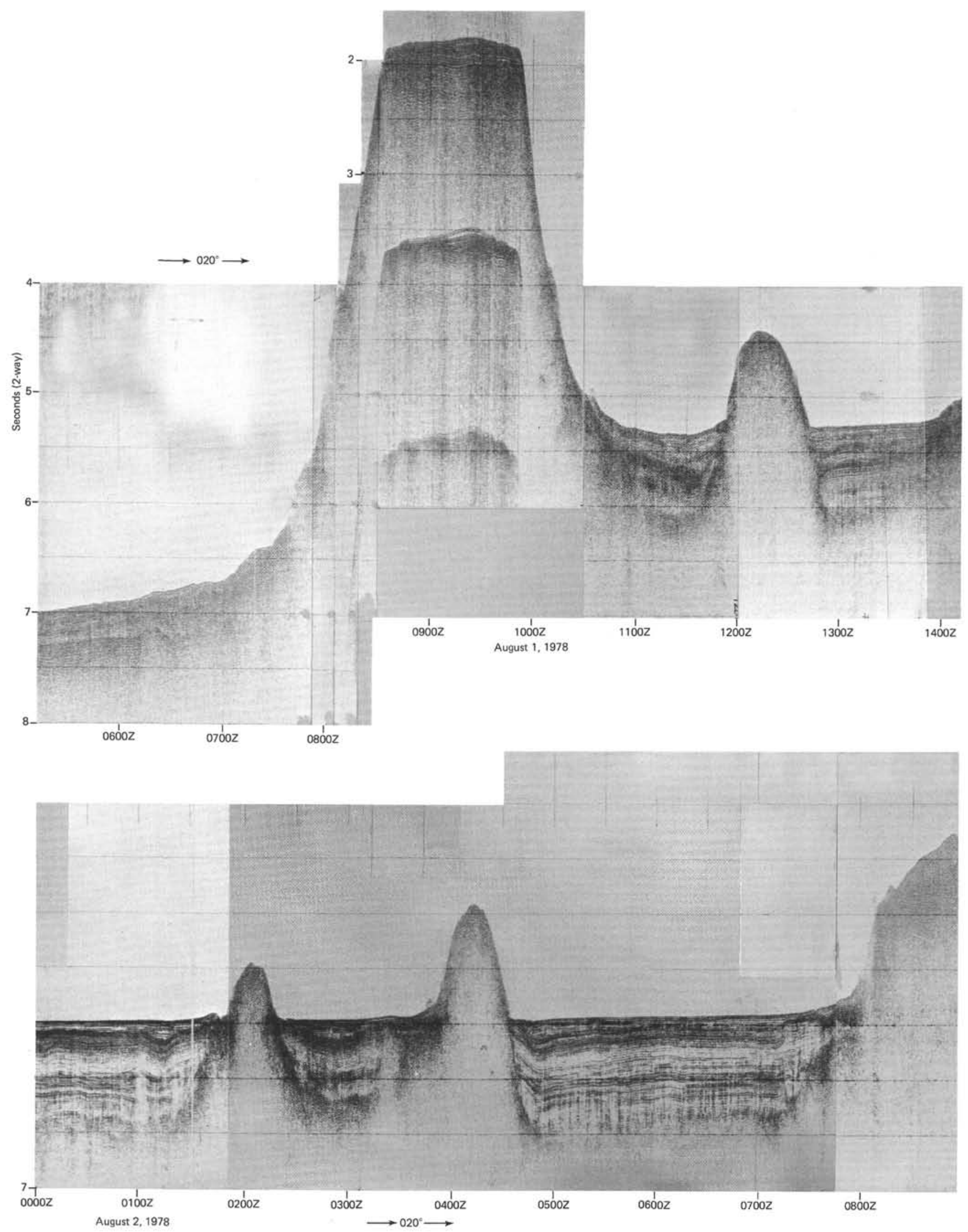

Figure 8. Seismic-reflection profile recorded by D/V Glomar Challenger, 1 and 2 August 1978, during approach to Site 463 from the south (see site report, this volume, for details). Speed about 8.5 knots. 

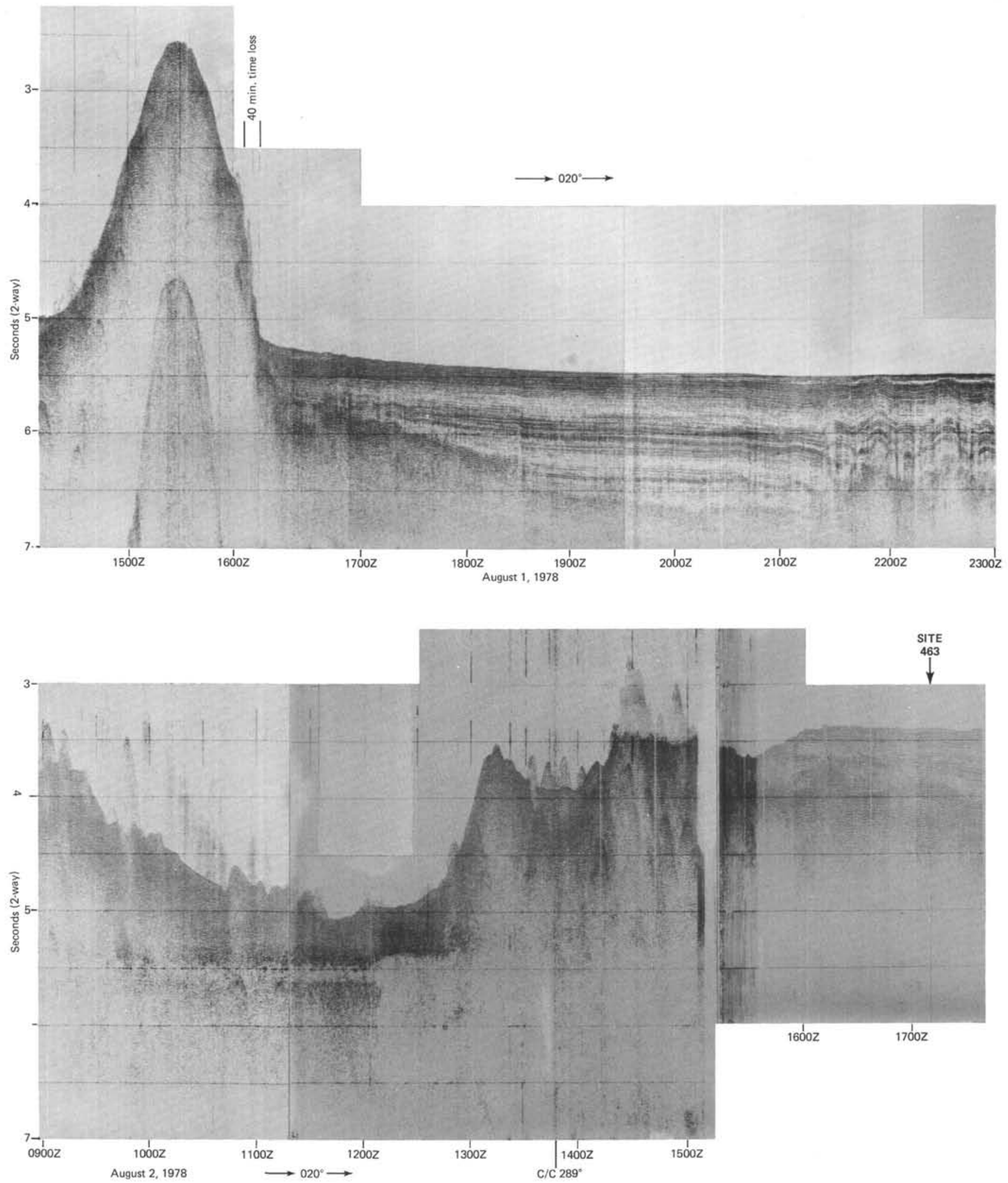

Figure 8. (Continued). 


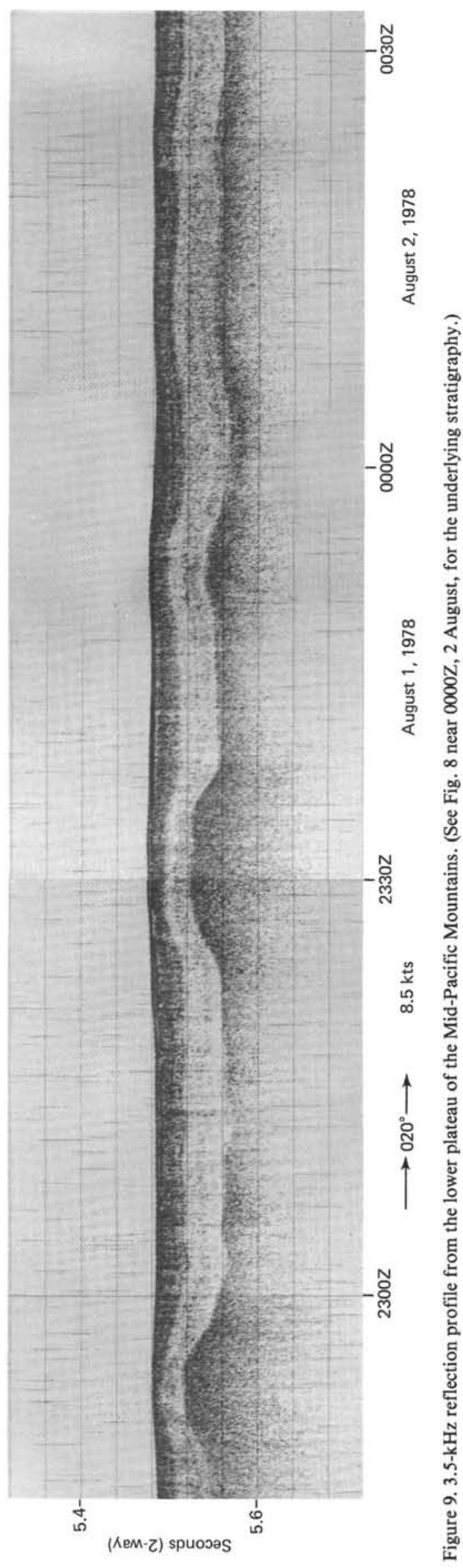

mains in diffuse form above Cores 60 to 62 , where upper Aptian ash horizons occur. Sedimentary Unit III (Cores 67-71), of early Aptian age, contains several ash layers which are dark greenish-gray, laminated to massive, and up to $5 \mathrm{~cm}$ in thickness. Significant amounts of ash occur within the limestones of Unit III; zeolites, usually clinoptilolite (Rateev et al., this volume), occur in the lower part, where mass-accumulation rates of the inorganic fraction reach their maximum (Fig. 11). Lower Aptian to Barremian limestones of Unit IV show high MARs of a smectite-dominated inorganic fraction. This unit was deposited in part by down-slope transport of materials, so the large volcanic component of these sediments may reflect erosion of an adjacent volcanic edifice, as well as direct airborne volcanic input.

The volcanogenic materials at Site 463 provide an intermittent record of central Pacific volcanic activity since the Early Cretaceous. High MARs of this component during Barremian to early Albian time (Fig. 11) may reflect the waning stages of the volcanism that resulted in the formation of the Mid-Pacific Mountains. Basement ages of the Ontong-Java Plateau (Site 289, DSDP Leg 30; Andrews, Packham, et al., 1975), Manihiki Plateau (Site 317, DSDP Leg 33; Schlanger, Jackson, et al., 1976), and northern Hess Rise (Site 464 report, this volume) all are Aptian to early Albian; this, together with the Site 463 data, provides evidence for a major mid-Cretaceous volcanic event (Fig. 12) that apparently formed several of the central Pacific aseismic rises (Vallier and Rea, 1980; Schlanger et al., 1981).

From the middle Albian through the Campanian, the clay-mineral assemblage is dominated by illite, the continent-derived clay mineral. Accumulation rates also decrease up-section until they reach a low of $0.01 \mathrm{~g} \cdot \mathrm{cm}^{-2}$. $10^{-3} \mathrm{yr}^{-1}$ in the Turonian to Campanian. Deposition of inorganic materials during this interval appears to have been dominated by land-derived eolian materials (Rea and Janecek, this volume; Vallier and Rea, 1980). In the Maastrichtian, MARs increase and smectite becomes important in the clay-mineral assemblage again (Fig. 11). This increase appears to represent a major volcanic event in the central and western Pacific Ocean during Campanian and Maastrichtian time (Fig. 12).

Cenozoic volcanic activity is not well documented at Site 463 . The clay-mineral assemblages are dominated by illite and chlorite plus kaolinite, with only minor smectite. Most of this material, then, is continent-derived eolian debris. Rea and Janecek (this volume) suggest that a relative MAR maximum during the early Pliocene may correspond to a relative maximum in both plate-margin and mid-plate (Kennett et al., 1977; Rea and Scheidegger, 1979) volcanic activity. Another MAR peak occurs during Plio-Pleistocene time, concurrent with another known pulse of volcanic activity, but the lack of smectite in these sediments suggests that the eolian input to Site 463 during the glacial period has been dominated by continent-derived material.

\section{PALEOGEOGRAPHY AND PALEOBATHYMETRY OF THE MID-PACIFIC MOUNTAINS}

The paleogeographic and paleobathymetric evolution of the Mid-Pacific Mountains can be deduced from the 
foregoing data. The subsidence of Site 463 on the western Mid-Pacific Mountains cannot be properly established at the present time, because volcanic basement was not reached (Fig. 13). The increasing frequency and thickness of horizons of displaced calcareous shallowwater components with increasing age in the oldest part of the section document the close proximity of regions near or above the sea surface (see also Ferry and Schaaf, this volume). Basaltic pebbles included in these beds document the presence of a volcano in the source area of this material. The addition of material displaced from the shallow areas decreased sharply during the Aptian, approximately 112 m.y. ago. However, indicators of shallow depositional environments during Aptian to Cenomanian time have been dredged from the tops and flanks of a number of guyots of the Mid-Pacific Mountains (Hamilton, 1956). Subaerially extruded, heavily weathered basalts overlain by shallow-water carbonates were reached at DSDP Site 171 (Winterer, Ewing, et al., 1973). These lithologies document for the Mid-Pacific Mountains a subsidence well in excess of $2 \mathrm{~km}$ during the past 100 m.y.

Following the model (Fig. 14) of Lancelot (1978), Site 463 was situated $120 \mathrm{~m}$.y. ago roughly at $20^{\circ} \mathrm{S}, 150^{\circ} \mathrm{W}$, and by 90 m.y. ago it had moved to $12^{\circ} \mathrm{S}, 160^{\circ} \mathrm{W}$; it crossed the equator 60 to 70 m.y. ago, then continued its northwesterly movement into the central North Pacific. If we assume that the volcanic events which led to the construction of the dominant portion of the Mid-Pacific Mountains had ceased at the time of deposition of the oldest sediments at Site 463 ( $\sim 120$ m.y. ago), then this structural high must have been a group of large and small islands whose extent diminished with increasing subsidence (Fig. 15). Large islands would have exerted an important influence upon the hydrography of the surface water masses and upon the depositional environments in the submarine regions adjacent to them. The existence of such islands probably explains the long duration of the phase of high accumulation rates at Site 463 beginning $120 \mathrm{~m} . y$. ago, and high variability of the fluxes of biogenic components (Fig. 7). This description of the paleogeographic evolution of the western MidPacific Mountain is supported by reworked shallowwater fossils which originated in neritic depositional environments around the oceanic island or on shoals, as long as they were close to the photic zone. The oldest shallow-water sediment found at Site 463 , and at the same time the oldest neritic fossils of the entire MidPacific Mountain, are observed in Barremian deposits; the younger ones are of Maastrichtian (possibly Danian) age (Hamilton, 1956).

\section{LITHO-, BIO-, AND MAGNETOSTRATIGRAPHY OF DSDP SITE 463}

\section{Lithostratigraphy of Site $\mathbf{4 6 3}$}

The over-800-meter-thick sedimentary sequence penetrated at Site 463 is subdivided into four lithologic units of widely differing compositions (Fig. 16; site report, this volume). Unit I is nannofossil ooze and nannofossil foraminifer chalk; Unit II consists of multicolored and silicified limestone; Unit III has tuffaceous and carbonaceous limestone; and Unit IV is made up of interbedded pelagic and clastic limestone. Except in Unit IV, which contains shallow-water-derived components in the clastic limestone beds, and Unit III, which contains a few thin horizons of tuffaceous and carbonaceous material (including land-derived plant detritus), the bulk of the sedimentary column consists of biogenic, pelagic sediment components or their diagenetic alteration products. A minor fraction of finegrained, land-derived, wind-transported clastic minerals is dispersed throughout the sedimentary column (Rea and Janecek, this volume). The most important factors in determining the characteristics of the sedimentary record are the properties of and the changes within the oceanic depositional environment.

\section{Bio- and Magnetostratigraphy of DSDP Site $\mathbf{4 6 3}$}

Biostratigraphic data on Site 463 were obtained mainly from observations of the following microfossil groups (Fig. 17): planktonic foraminifers (Boersma; Krasheninnikov; Vincent; all this volume); radiolarians (Schaaf, this volume); calcareous nannofossils (Čepek; Roth; both this volume). Calcareous microfossils were used to date most of the Quaternary to Barremian sedimentary section, more than 800 meters thick. The calcareousnannofossil and planktonic-foraminifer zonations of the upper 560 meters of sediment are in good agreement. Below that level, however, sediments are dated by calcareous nannofossils, because of the absence of foraminifers. Siliceous microfossils could only be used for zonations in the Cretaceous section, because no diatoms were observed, and because radiolarians were found only in a few cores in sediments younger than middle Albian. However, in the lower Aptian to lower Albian sediments, recrystallized radiolarians and internal molds of radiolarians composed of pyrite and iron oxides occur in sand layers; they probably are displaced. In the lowermost sediments of the site, mostly of Barremian age, well-preserved radiolarian faunas were found throughout the section. The radiolarian zonation of the Lower Cretaceous sediments appears to be in general agreement with a nannoplankton zonation, buts its calibration to an absolute time scale and to other fossil groups is poorly documented. It is important, therefore, to note that a sequence of magnetic-polarity changes (Sayre, this volume) observed in the cores of Barremian to early Albian age can be correlated to the M0-M3 magnetic anomalies of the Mesozoic magnetic-reversal time scale.

\section{Sedimentation Rates at Site 463}

Age assignments of the biostratigraphic zones (Fig. 17) have been made using the time scales of Berggren (1973) and Van Couvering and Berggren (1977) for the Neogene, and Hardenbol and Berggren (1978) for the Paleogene. For the Cretaceous, the zonal schemes of Thierstein $(1976,1978)$ have been used and correlated to the numerical time scales proposed by van Hinte (1976).

Average sedimentation rates at Site 463 , shown in Figure 18, can be used to calculate accumulation rates (Fig. 7) of the bulk sediment (Thiede and Rea, this volume); they illustrate how frequently and how much 


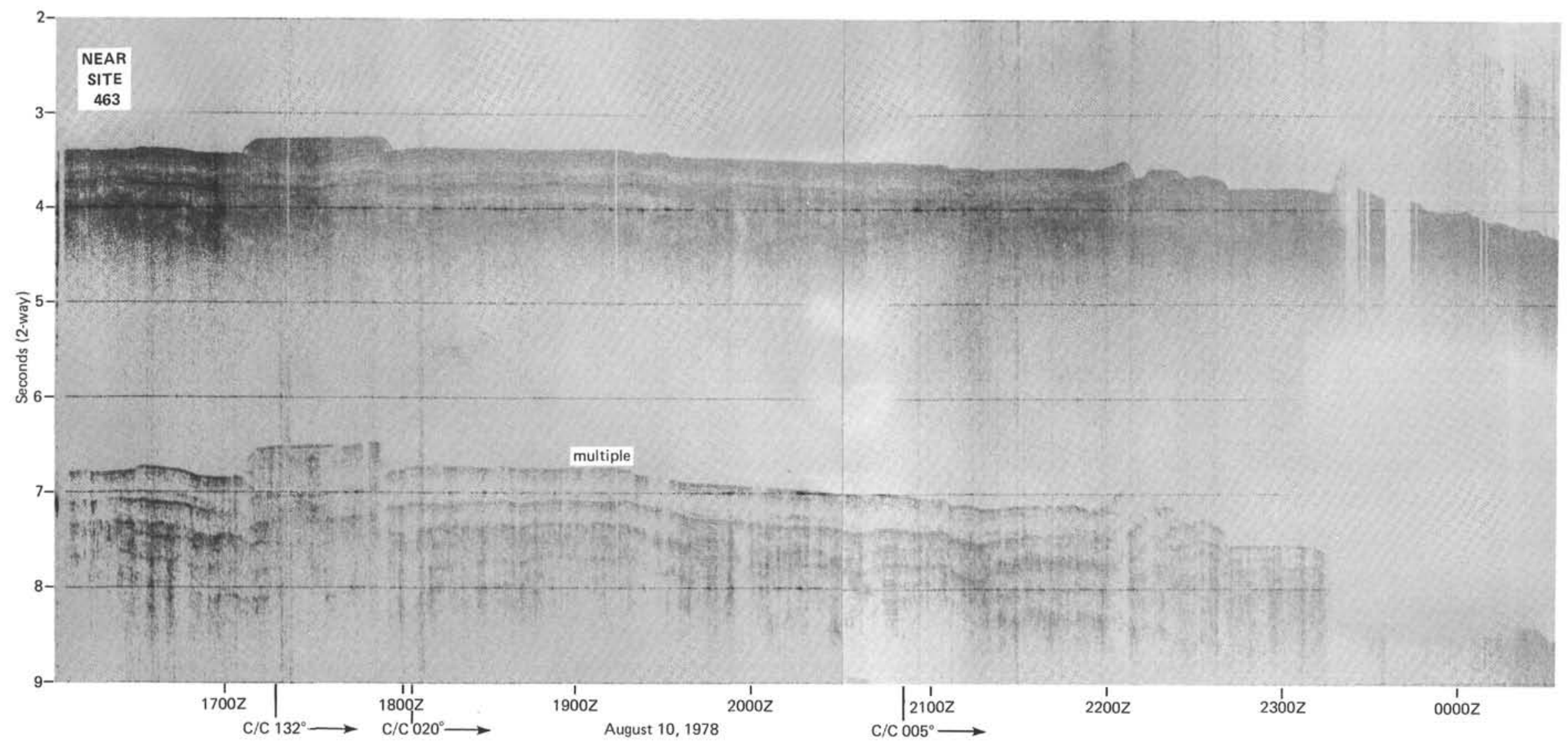




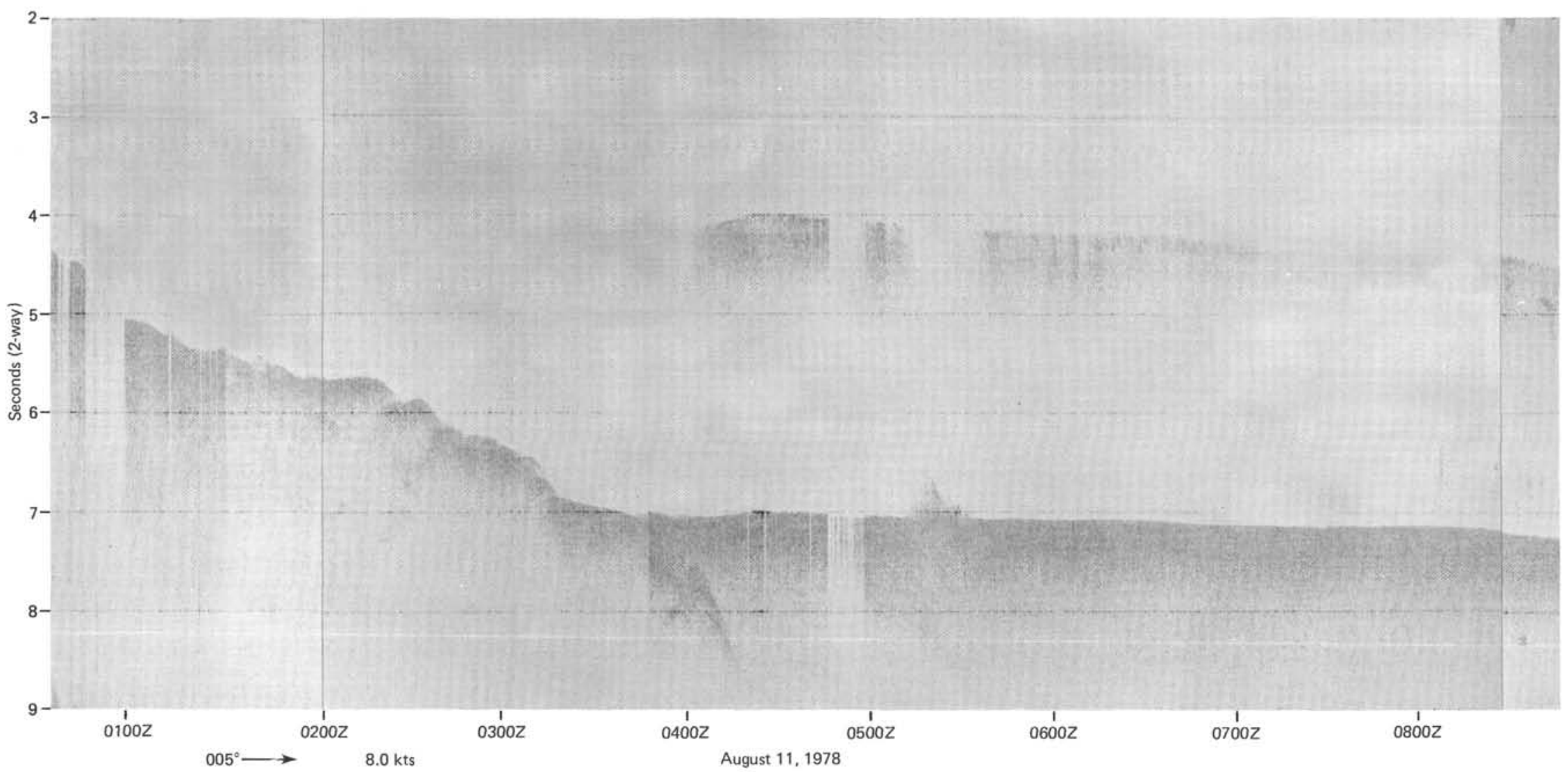

Figure 10. Ten-second seismic-reflection profile recorded by D/V Glomar Challenger during northward departure from Site 463 on the Mid-Pacific Mountains. 
Table 2. Igneous rocks from the Mid-Pacific Mountains region.*

\begin{tabular}{|c|c|c|c|}
\hline Site & Location & Lithologies & References \\
\hline Aires 5.7 & $\begin{array}{l}\text { Shepard Guyot } \\
19^{\circ} 14.5^{\prime} \mathrm{N}, 179^{\circ} 33.4^{\prime} \mathrm{W}\end{array}$ & Basalt and volcanic ash & Heezen et al. (1973 \\
\hline Aires 5-9 & $\begin{array}{l}\text { Jacqueline Guyot } \\
19^{\circ} 19.6^{\circ} \mathrm{N}, 176^{\circ} 52.0^{\prime} \mathrm{E}\end{array}$ & Basalt and volcanic ash & Heezen et al. (1973) \\
\hline Aires $5-16$ & $\begin{array}{l}\text { Deep sea escarpment } \\
21^{\circ} 33^{\prime} \mathrm{N}, 173^{\circ} 520^{\circ} \mathrm{E}\end{array}$ & Basalt fragments & Heezen et al. (1973) \\
\hline Aires 5-19 & $\begin{array}{l}\text { Wilde Guyot } \\
21^{\circ} 09.0^{\prime} \mathrm{N}, 163^{\circ} 22.04^{\prime} \mathrm{E}\end{array}$ & $\begin{array}{l}\text { Rounded trachyte cobble; } \\
\text { hyaloclastites }\end{array}$ & $\begin{array}{l}\text { Heezen et al. (1973); } \\
\text { Natland (1976) }\end{array}$ \\
\hline Aires $5-21$ & $\begin{array}{l}\text { Miami Guyot } \\
21^{\circ} 42.78^{\prime} \mathrm{N}, 161^{\circ} 52.66^{\prime} \mathrm{E}\end{array}$ & Volcanic breccia & Heezen et al. (1973) \\
\hline Aires $5-22$ & $\begin{array}{l}\text { Lamont Guyot } \\
21^{\circ} 29.0^{\prime} \mathrm{N}, 159^{\circ} 37.5^{\prime} \mathrm{E}\end{array}$ & Volcanic breccia & Heezen et al. (1973) \\
\hline Aires $5-23$ & $\begin{array}{l}\text { Lamont Guyot } \\
21^{\circ} 29.0^{\circ} \mathrm{N}, 159^{\circ} 32.3^{\prime} \mathrm{E}\end{array}$ & $\begin{array}{l}\text { Basalt fragments; } \\
\text { tuff breccia }\end{array}$ & Heezen et al. (1973) \\
\hline Aires 5-25 & $\begin{array}{l}\text { Scripps Guyot } \\
23^{\circ} 42.2^{\prime} \mathrm{N}, 159^{\circ} 32.8^{\prime} \mathrm{E}\end{array}$ & Potassic nephelinite & $\begin{array}{l}\text { Heezen et al. (1973): } \\
\text { Natland (1976) }\end{array}$ \\
\hline Aires 5-26 & $\begin{array}{l}\text { Scripps Guyot } \\
23^{\circ} 48.9^{\prime} \mathrm{N}, 159^{\circ} 26.2^{\prime} \mathrm{E}\end{array}$ & Basalt fragments & Heezen et al. (1973) \\
\hline 7 TOW 6-137-D & $\begin{array}{l}\text { Unnamed seamount } \\
14^{\circ} 27^{\prime} \mathrm{N}, 168^{\circ} 59^{\prime} \mathrm{W}\end{array}$ & $\begin{array}{l}\text { Phonolite; trachyte } \\
\text { conglomerate }\end{array}$ & Natland (1976) \\
\hline 7 TOW 6-138-D & $\begin{array}{l}\text { Ridge trending WNW } \\
15^{\circ} 39^{\prime} \mathrm{N}, 169^{\circ} 18^{\prime} \mathrm{W}\end{array}$ & Potassic nephelinite & Natland (1976) \\
\hline 7 TOW 6-142-D & $\begin{array}{l}\text { Ridge trending NNW } \\
18^{\circ} 00^{\prime} \mathrm{N}, 169^{\circ} 05^{\prime} \mathrm{W}\end{array}$ & Trachyte & Natland (1976) \\
\hline 7 TOW 6-144-D & $\begin{array}{l}\text { ENE-trending ridge } \\
21^{\circ} 32^{\prime} \mathrm{N}, 167^{\circ} 56^{\prime} \mathrm{E}\end{array}$ & $\begin{array}{l}\text { Olivine theralite; } \\
\text { alkalic olivine basalt }\end{array}$ & Natland (1976) \\
\hline MP $25 \mathrm{~F}-2$ & $\begin{array}{l}\text { Horizon Guyot } \\
19^{\circ} 07^{\circ} \mathrm{N}, 169^{\circ} 44^{\prime} \mathrm{W}\end{array}$ & Alkalic olivine basalt & Hamilton (1956) \\
\hline MP $26 \mathrm{~A}-3$ & Guyot 19171 & Olivine basalt & Hamilton (1956) \\
\hline MP-28 & Guyot 20171 & Altered basalt & Hamilton (1956) \\
\hline MP 33-C & $\begin{array}{l}\text { Hess Guyot } \\
17^{\circ} 50^{\circ} \mathrm{N}, 174^{\circ} 15^{\prime} \mathrm{W}\end{array}$ & Olivine basalt & Hamilton (1956) \\
\hline DSDP Site 171 & $\begin{array}{l}\text { Horizon Guyot } \\
19^{\circ} 07.9^{\prime} \mathrm{N}, 169^{\circ} 27.6^{\prime} \mathrm{W}\end{array}$ & Olivine basalt & Bass et al. (1973) \\
\hline DSDP Site 313 & $\begin{array}{l}\text { Basin between guyots } \\
20^{\circ} 10.5^{\prime} \mathrm{N}, 170^{\circ} 57.15^{\prime} \mathrm{W}\end{array}$ & Alkalic basalt & Marshall (1975) \\
\hline
\end{tabular}

- Compilation from Hamilton (1956), Bass et al. (1973), Heezen et al. (1973), Marshall (1975), and Natland (1976).

the flux of sediment components to Site 463 has changed through time. With the exception of a short interval in Campanian time, Cretaceous sedimentation rates were higher than $5 \mathrm{~m} / \mathrm{m}$.y. Moreover, with the exception of the Maastrichtian deposits just below the long hiatus across the Cretaceous/Tertiary boundary, when sedimentation rates peaked at $50 \mathrm{~m} / \mathrm{m} . \mathrm{y}$., a general trend can be observed of sedimentation rates decreasing from very high values in the oldest part of the penetrated section to values less than $5 \mathrm{~m} / \mathrm{m}$.y. in Upper Cretaceous and Cenozoic sediment. The Lower Cretaceous section is expanded because of the additional massive influx of displaced shallow-water-derived sediments which accumulated in layers of clastic limestone.

Several hiatuses can be documented in detail (Maastrichtian through part of the Eocene, Eocene-Oligocene, and uppermost Oligocene through middle Miocene) because the site has been cored continuously. A condensed interval with possible hiatuses of short duration were observed in Coniacian-Campanian sediments. In general, the Cenozoic sedimentary sequence of only 47 meters thickness is condensed in comparison to the more than 770-meter-thick Cretaceous section.

\section{THE DEPOSITIONAL ENVIRONMENTS OF THE MID-PACIFIC MOUNTAINS DURING THE PAST 120 M.Y.}

After establishing the regional paleogeographic and paleobathymetric framework and the composition and age of the sediments, we can discuss the depositional environments of the various lithofacies. Because of our inability to reach the volcanic basement of the western Mid-Pacific Mountains and the autochthonous neritic deposits which are believed to cap it, the discussion will focus on aspects of the time when the site was under the influence of pelagic sedimentation at intermediate water depths. Volcanogenic sediments intercalated with these deposits are addressed in other chapters of this volume. The inorganic, non-volcanic sediment fraction, which is believed to have reached the site largely as airborne material (Rea and Janecek, this volume), allows us to make inferences about changes in atmospheric circulation throughout the past 120 m.y. Reworked shallow-water clastic calcareous components in the lowermost lithologic unit document the proximity of oceanic islands or shoals which must have disturbed and altered the pelagic environment considerably. We are unable to date precisely the final submergence of the islands, but land-derived plant detritus (Mélières et al., this volume; Dean et al., this volume) in the "anoxic" deposits suggests that islands existed in this area at least until Aptian time. However, marine neritic fossils displaced into deeper waters and found in sediments as young as Maastrichtian (Thiede et al., this volume) indicate that some of the highest guyots on the western Mid-Pacific Mountains must have reached into the photic zone until the Late Cretaceous, and perhaps even until very early Tertiary time. The depositional environments which developed during the Cenozoic cannot be discussed completely, because of the large hiatuses and very low sedimentation rates.

\section{History of Pelagic Sedimentation}

\section{The Oldest Pelagic Limestones}

Pelagic limestone of Lithologic Unit IV, whose deposition was interrupted by the episodic influx of clastic, shallow-water derived carbonates from nearby neritic environments, is shown in Figure 19. The amount of clastic material, the thickness of the horizons with clastic material, and the maximum size of the clasts decrease up-section, with decreasing age of the sediments. The pelagic deposits in the deepest cores consist of light-gray and white limestone. The origin of the primary input cannot be determined exactly, because the dominant portion of the carbonate is recrystallized. However, these pelagic limestones are very fine-grained; they comprise a certain fraction of poorly preserved calcareous nannofossils (Čepek, this volume), and they lack remains of foraminifers, although they have produced well-preserved radiolarian fossil assemblages. Therefore, we believe that the limestone beds originated from nannofossil ooze that accumulated rapidly at intermediate water depths, close to the oceanic islands which existed at that time.

A number of these beds contain less carbonate, because volcanic ash dilutes the pelagic sediments (Fig. 19). The uppermost three cores of this unit show the cycle-like color alternations of various shades of olive, green, and white, similar to those in Units II and III. The sediments also are burrowed; they contain discontinuous wispy laminae, and streaks are common. Radiolarian skeletons in sandy horizons in the upper part of the unit are poorly preserved and appear in certain intervals of the deepest cores to have been transported. These observations, together with the occurrence of the many clastic limestone layers, suggest a rather unstable 


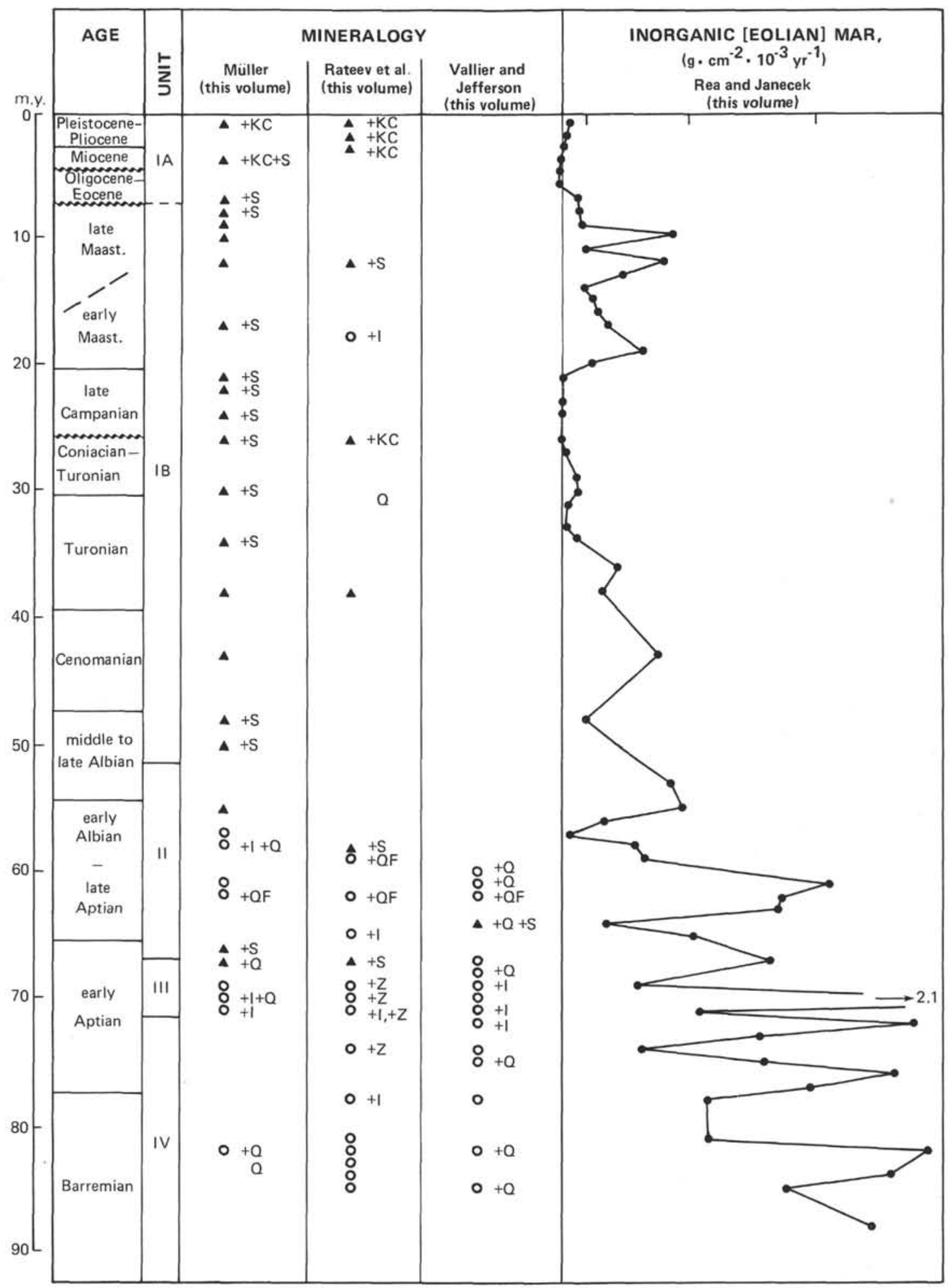

Figure 11. Inorganic sediment fraction at Site 463. All data from chapters in this volume. Symbols show dominant clay mineral, shaded triangle for illite, and open circle for smectites (which include mixed-layer clays of Rateev et al.); otherwise: $\mathrm{KC}=$ kaolinite and chlorite, $\mathrm{Q}=$ quartz, $\mathrm{QF}=$ quartz and feldspar, $\mathrm{Z}=$ zeolite, $\mathrm{S}=$ smectite, and $\mathrm{I}=$ illite. 


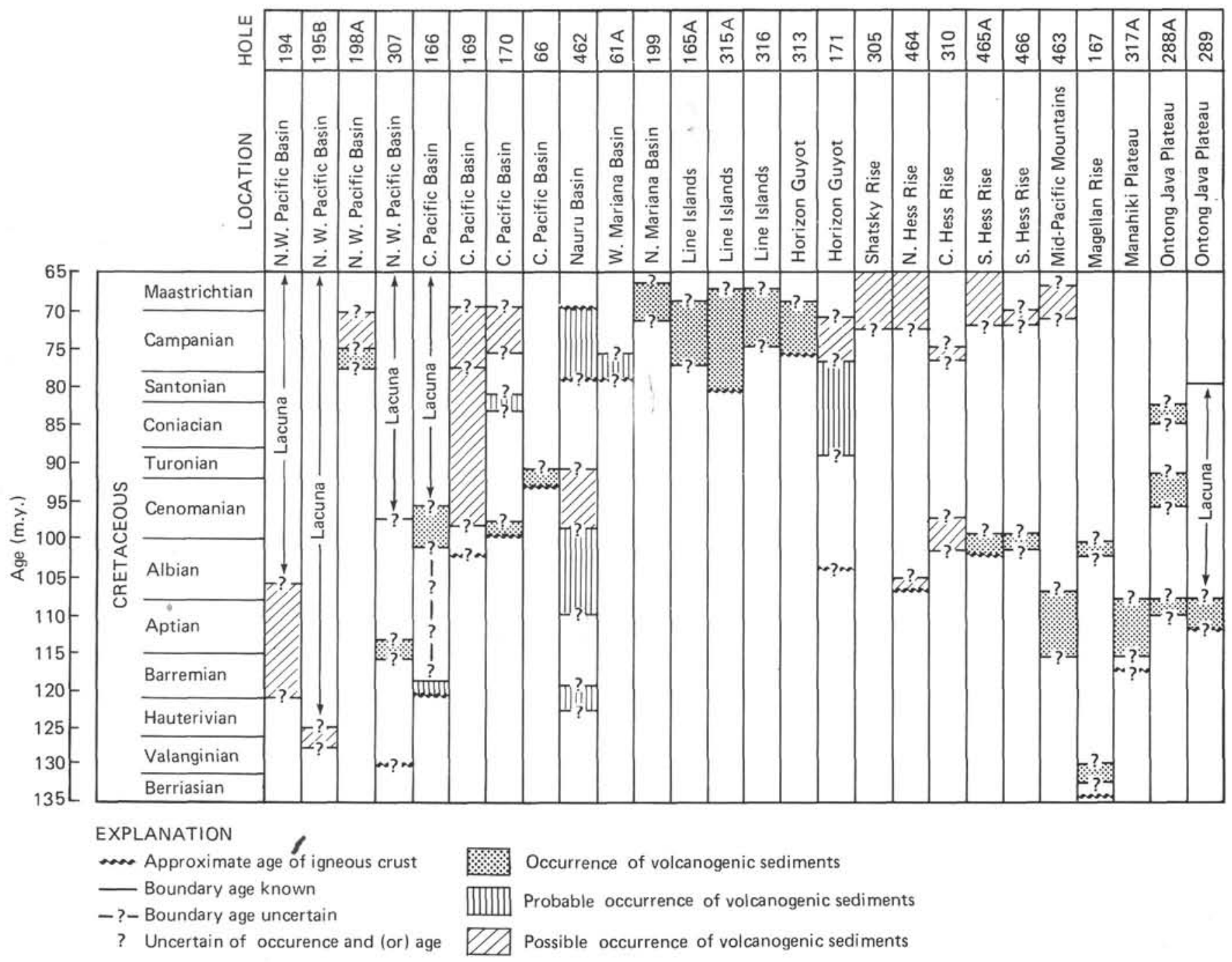

Figure 12. Volcanogenic sediments in stratigraphic columns of DSDP sites in the western Pacific Ocean. Approximate age of igneous crust is included. Modified from Rea and Vallier (in prep.).

depositional environment at intermediate water depths, well below the photic zone and wave base.

\section{Tuffaceous and Carbonaceous Limestones}

The Aptian sediments of Unit III overlie the pelagic limestones of Unit IV and are characterized by altered volcanic ash beds and beds of carbonaceous sediment. The dark, laminated, shaly horizons with high organiccarbon contents are of particular interest because they occur in a stratigraphic interval which elsewhere in the world oceans contains similar sediments. It has been possible to collect long and relatively detailed sections of organic-carbon-rich Cretaceous strata from the Atlantic and Indian Oceans during early stages of deep-sea drilling, but the Pacific record has been sparse and incomplete. Only during DSDP Leg 62 were complete records of "anoxic" strata recovered at continuously cored drill sites on the flanks of the Mid-Pacific Mountains and Hess Rise in the central North Pacific Ocean (Dean et al., this volume). The earliest record of "anoxic" sediments was found on Horizon Guyot during
DSDP Leg 17 (Site 171), at the eastern end of the MidPacific Mountains, where greenish-gray, slightly mottled, in part finely laminated, calcareous, volcanic siltstone and claystone of Turonian age containing more than $2 \%$ organic carbon (Core 171-25) were observed. They overlie a sequence of volcanic sandstone, shallowwater limestone, and basalt of probable Cenomanian age.

Three beds of siliceous limestone containing more than $2 \%$ organic carbon occur in Hole 463 within the lower Aptian pelagic-limestone sequence (Fig. 20). The organic-carbon-rich intervals belong to the lower Aptian Chiastozygus litterarius nannofossil zone (Ćepek, this volume). The age scale in Figure 20 is based on linear interpolation between the upper and lower boundaries of this zone, which represents the interval from approximately 112 to 115 m.y. ago (van Hinte, 1976). Assuming a constant sedimentation rate during this time, the ages of the individual intervals with high concentration of organic carbon and their durations can be estimated within $10^{4}$ years. All three seem to be 


\section{SITE 463}

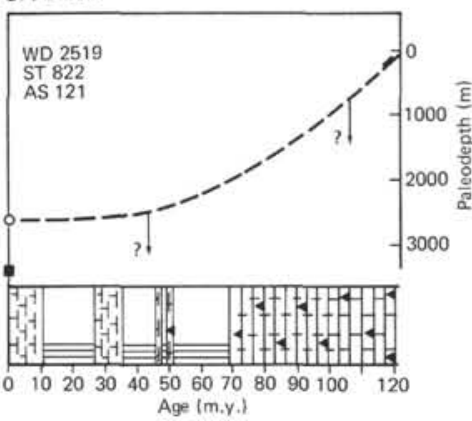

SITE 171

Time after formation of basement (m.y.) $100908070605040302010 \quad$

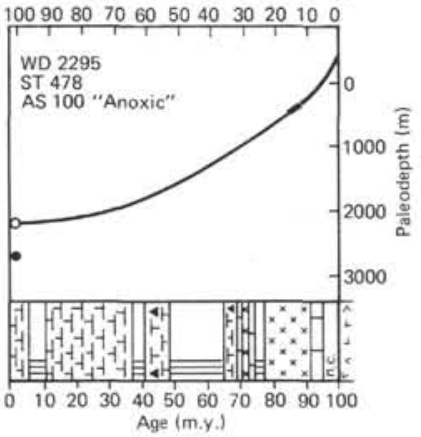

Figure 13. Subsidence curves for DSDP Sites 171 and 463 on the MidPacific Mountains. Basic data from site reports (this volume; Winterer, Ewing et al., 1973).

slightly older than $113 \mathrm{~m} . \mathrm{y}$. The earliest and thinnest of the three laminated and organic-carbon-rich intervals began to accumulate about $113.2 \mathrm{~m} . \mathrm{y}$. ago, the second about 113.18 to 113.19 m.y. ago, and the third about 113.08 to 113.09 m.y. ago.

The laminated intervals within dark-gray, mottled, silicified limestone suggest that a depositional environment favorable for the preservation of organic carbon may have developed. Many of the laminated beds of the stratigraphic interval, however, do not contain particularly high concentrations of organic carbon. The three organic-carbon-rich intervals of this site all have very sharp lower boundaries (Figs. 20 and 21), indicating that oxygen deficiency was established rapidly. The upper boundaries are gradational, suggesting that it took a few thousand to a few tens of thousands of years for the environment to return to an oxygenated condition. They do not display clear evidence of emplacement by turbidity currents; however, they do contain more clayey material than the sediment above and below, and part of the organic material consists of land-derived plant detritus (Mélières et al., this volume), which suggests an increased contribution of reworked material.

The rocks in Cores 70 and 71 of Hole 463 (623.0$632.5 \mathrm{~m}$ ) are dominantly highly silicified limestone, with some chert and few layers of volcanic ash. Radiolarians are abundant, but they are poorly preserved compared with the radiolarians above and below (Schaaf, this volume). This suggests that the silica for diagenetic silicification of the limestones was biogenic; hence, there was high surface-water fertility, although the site was far south (Figs. 14 and 15) of the equatorial divergence during Early Cretaceous time (Sayre, this volume). As a result of silicification, the concentration of $\mathrm{CaCO}_{3}$ is generally less than $30 \%$, and the concentrations of $\mathrm{Si}$ are as high as $40 \%$ (Dean, this volume).

The most remarkable sedimentary structures in Cores 69 to 72 are the laminations in the dark-gray, clayey intervals intercalated with the bluish-white to dark-greenish-gray, mottled limestones (Fig. 21). The laminated intervals range from a few centimeters to more than 60 $\mathrm{cm}$ in thickness, but only three contain concentrations of organic carbon greater than $2 \%$. The darker intervals occur throughout Cores $69(604.0-613.5 \mathrm{~m})$ to 72 (632.5-642.0 meters), but they are most abundant in Cores 70 and 71 , where it is difficult to distinguish them from thin volcanic-ash layers. The higher intervals of the cores are often mottled and have produced the large burrow illustrated in Figure 22.

The lithologies of organic-carbon-rich rocks from the upper Mesozoic central Pacific Ocean are highly variable, although they all were deposited in true pelagic environments on oceanic plateaus. Because these locations are elevated above the surrounding ocean-basin floor, they have been protected against massive fluxes of suspended terrigenous matter of continental origin, although they may have received minor quantities of airborne material. Occurrences of carbonized vascularplant debris in lower Aptian sediments at Site 463 (Timofeev and Bogolyubova, this volume; Melieres et al., this volume), and in an 80-meter-thick horizon of upper Aptian gray claystones at Site 462 in the Nauru Basin (Jenkyns and Schlanger, 1981), suggest that there may have been a considerable influx of organic matter from nearby land areas. These observations are supported by pyrolysis analyses (Dean et al., this volume) of Site 463 samples, which point to a relatively low hydrogen index, but high oxygen index; the organic matter of these samples appears to contain an important fraction of Type III kerogen (Tissot et al., 1974). Some of the samples of Site 463 , however, have a hydrogen index that is intermediate between Type II and Type III kerogen, suggesting that the organic-carbon-rich horizons may contain variable mixtures of Type II (typical marine) and Type III (terrestrial on highly oxidized) matter. The proportion of marine organic material generally increases with increasing organic-carbon concentrations. The same samples also contain high-molecular-weight, odd-numbered $n$-alkanes derived from cuticular waxes of higher plants (Dean et al., this volume). Mélières et al. (this volume) have demonstrated that several episodes of organic-matter deposition can be discerned in the midCretaceous: a lower interval of light-colored, burrowed sediments with undifferentiated organic matter; an intermediate interval with organic matter of terrestrial and marine origin (either mixed or alternating); and an upper interval of very dark, laminated sediments with organic matter entirely of marine origin.

All Pacific pelagic sections which contain intervals of "anoxic" organic-carbon-rich strata originally contained calcareous and siliceous components which now 


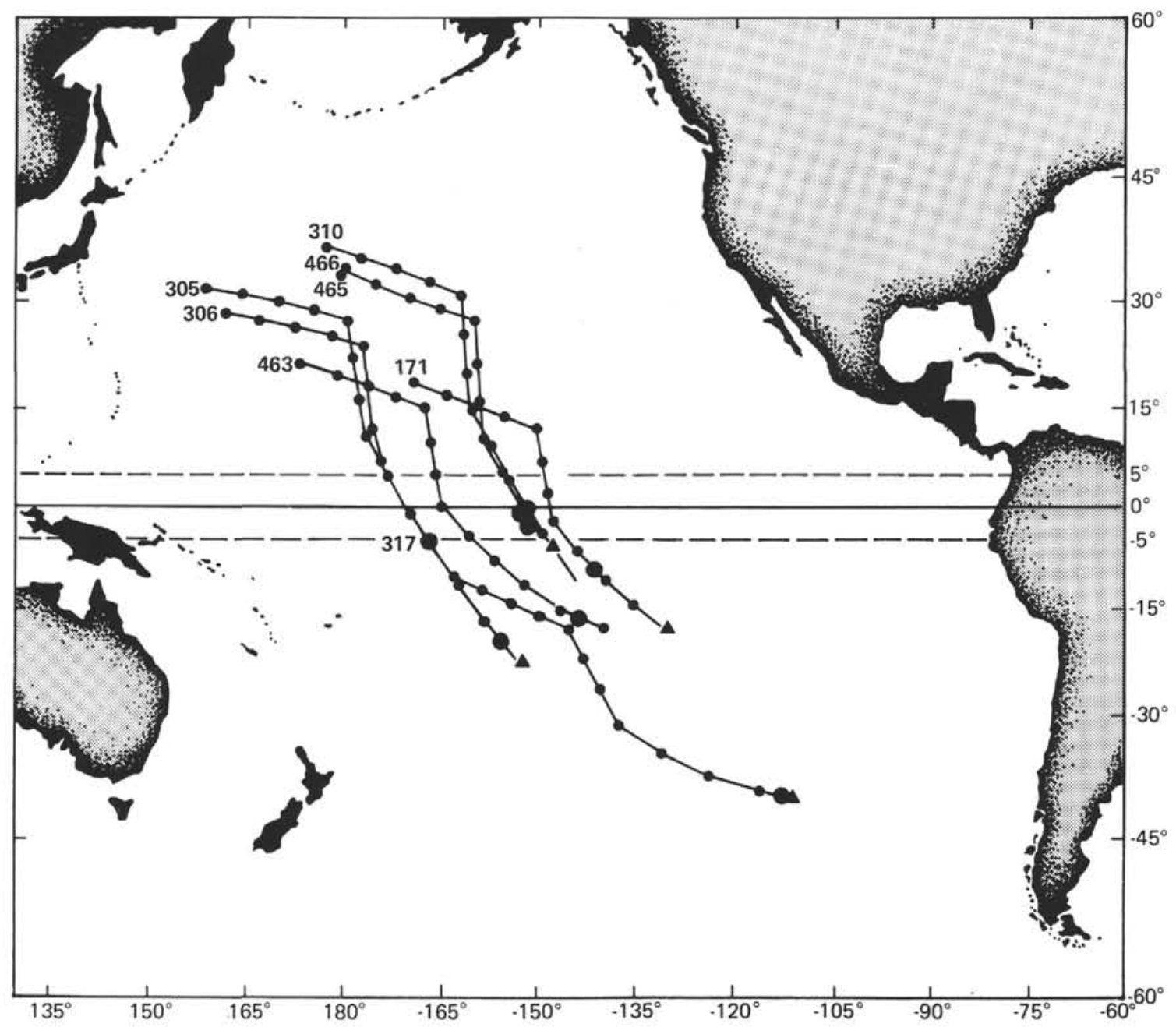

Figure 14. Horizontal movements of DSDP sites on the Pacific Plate since mid-Cretaceous time (according to the model of Lancelot, 1978). Cretaceous sections with occurrence(s) of "anoxic" sediments were penetrated at all marked sites. The paleogeographic positions of the sites during the development of the oxygen-deficient depositional environments are marked by large round dots. Small dots mark the positions of the sites at 10-m.y. increments. Triangles indicate basalt at the base of the penetrated section.

appear as alternations of chalk or limestone and chert layers. These strata represent depositional environments of relatively high rates of sedimentation of biogenic pelagic components. Clinoptilolite, quartz (chalcedony), and opal-CT (Mélières et al., this volume) probably are diagenetic products related to siliceous fossils. Barite, which occurs in minor amounts, may also be biogenic (Dean and Schreiber, 1978), because it is correlated with a silica-rich depositional environment (Mélières et al., this volume). High concentrations of pyrite in these sediments correlate with high concentrations of organic carbon.

Although the "anoxic" strata are dominantly biogenic, they also contain a certain fraction of non-biogenic material. There is a correlation between the laminated, organic-carbon-rich deposits and volcanogenic deposits, which consist of volcanic sandstones, ash layers, or clay horizons whose clay minerals have been derived mostly from altered volcanic materials. The dominant part of the clay minerals at Site 463 (Mélières et al., this volume) is smectite and illite which probably evolved diagenetically from smectite. The Site 463 sediments also contain a considerable amount of amorphous material, which consists mainly of volcanogenic aluminosilicates (Mélières et al., in press); both potash feldspar and plagioclase have been found throughout the "anoxic" sediments at Site 463 and are probably directly or indirectly of volcanic origin. Rea and Janecek (this volume) have also detected minor amounts of airborne material in the sediments at Site 463.

\section{Multicolored Limestones}

Volcanic-ash frequency decreases drastically at the upper boundary of the tuffaceous and carbonaceous limestones of the underlying unit. The overlying multicolored pelagic limestones show apparently cyclic interbeds of greenish-gray limestone with gray, white, or reddish limestone on the scale of about 1 to $20 \mathrm{~cm}$ (Fig. 23). The dominant sediments of this unit are recrystallized carbonate, but nannofossils and foraminifers are still recognizable in most smear slides. Thick intervals of the multicolored limestones are intensively silicified, but 

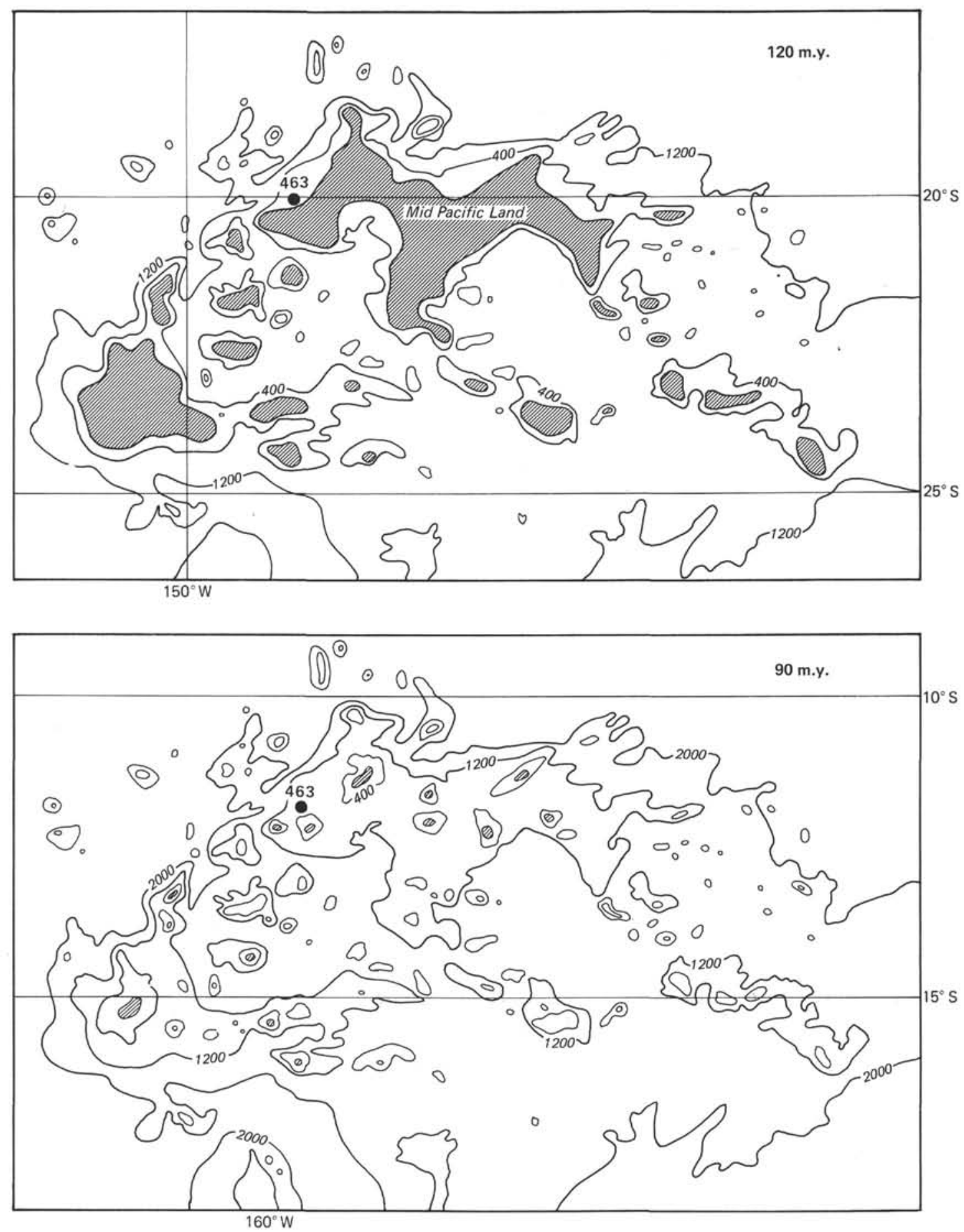

Depths in fathoms

Figure 15. Paleobathymetry and paleogeography of the Mid-Pacific Mountains approximately 120 and 90 m.y. ago. The paleolatitude has been reconstructed from the plate-rotation model of Lancelot (1978). For the modern bathymetry, see Figure 1.

siliceous microfossils (radiolarians) could be identified only in the lowermost cores, where they occur in sandy horizons. The cyclic color alterations are confined to fine-grained pelagic sediment, although color changes are also often observed at the boundaries of the sandy horizons which contain reworked material. The nature of the processes generating the cyclicity-which seems to be a phenomenon at many drill sites, not only in the Pacific Ocean, but also in the Atlantic Ocean and in stratigraphic intervals elsewhere (Dean et al., 1978) has not yet been completely resolved.

The Aptian-Albian multicolored limestones of Site 463 contain many sedimentary structures (Fig. 24) which suggest a highly variable depositional environment. A 
SITE 463

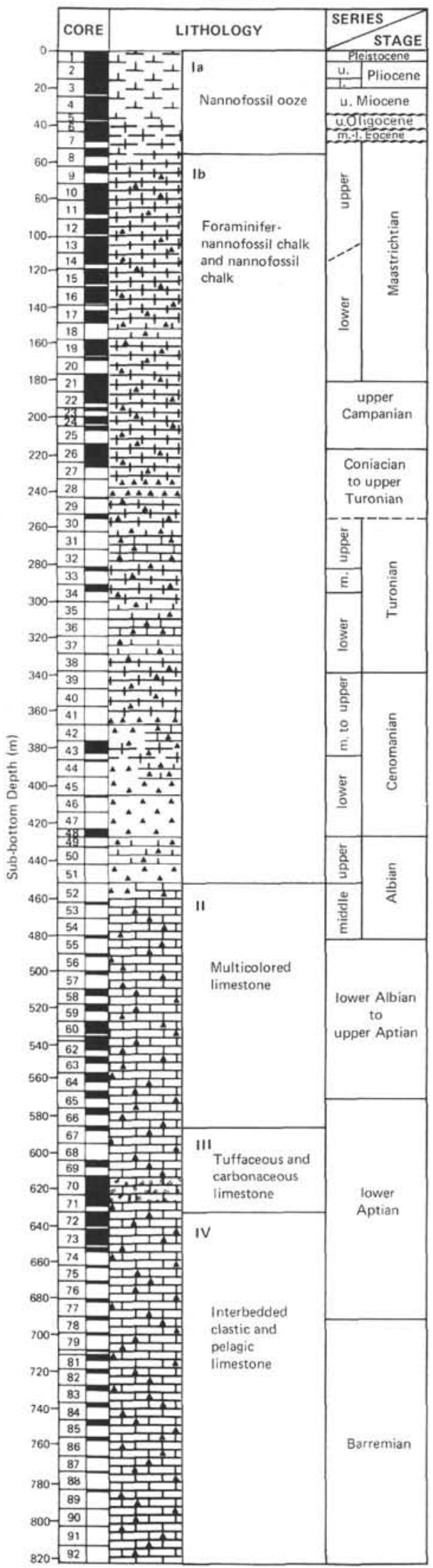

Figure 16. Simplified stratigraphy of DSDP Site 463. number of graded beds consisting entirely of pelagic material occur in the upper part of this unit. The upper parts of these graded beds are nannofossil limestones, whereas the bases are enriched in foraminifers and radiolarians. Some layers have erosional basal contacts. Many intervals in these sediments show nearly horizontal wavy laminations which in places transect the entire core. Burrows have been observed throughout the unit, indicating the former presence of benthic organisms, although a few intervals-usually the lightest in colorappear massive and uniform. Many burrows are flattened by compaction (Fig. 24). These sediments document a period of pelagic biogenic sedimentation with high accumulation rates and dilution by the addition of pelagic, probably contemporaneous material from upslope areas. Bottom-water currents apparently stirred the sediment continuously, although they were not strong enough to remove major quantities of the sediment. Collapse(?) structures suggest that some of the sediment might have been lithified, or at least semilithified, shortly after deposition, which would have impeded erosion by bottom currents.

\section{Cretaceous Chalks}

The multicolored-limestone unit is overlain by a more-than-400-meter-thick sequence of foraminifernannofossil and nannofossil chalks of mid- and Late Cretaceous age. They accumulated at highly variable rates (Fig. 7) and document a time when this part of the Mid-Pacific Mountains was at intermediate water depths (Fig. 13), under the sterile surface waters of the central subtropical water mass of the South Pacific Ocean, when it approached the Cretaceous Equator from the south and subsequently crossed under the highly productive equatorial current regime (Fig. 14). The record of the Late Cretaceous high accumulation rates terminates abruptly, because of the large hiatus which separates the Maastrichtian chalks from the lower Eocene nannofossil oozes.

The composition of the Cretaceous foraminifer-nannofossil and nannofossil chalks is very homogeneous, and only the proportion of the foraminifers changes slightly down-core. The chalk beds are highly uniform in their chert-free intervals, and they do not show sedimentary structures in their upper part. However, mottling, burrows, and laminations are more common in the lowermost part (Fig. 25). Chert layers make up a very important proportion of the entire interval and resulted often in rather poor core recovery. The lower boundary of the chalks was placed at the transition from chalk to limestone, which can also be observed as a change from the strongly recrystallized carbonate to unrecrystallized nannofossils and foraminifers; it coincides with the disappearance of the cyclic color variations so typical of the underlying multicolored limestones.

\section{Cretaceous and Lower Tertiary Cherts}

Chert layers and chert nodules occur throughout the Barremian to Eocene part of the sedimentary column of 


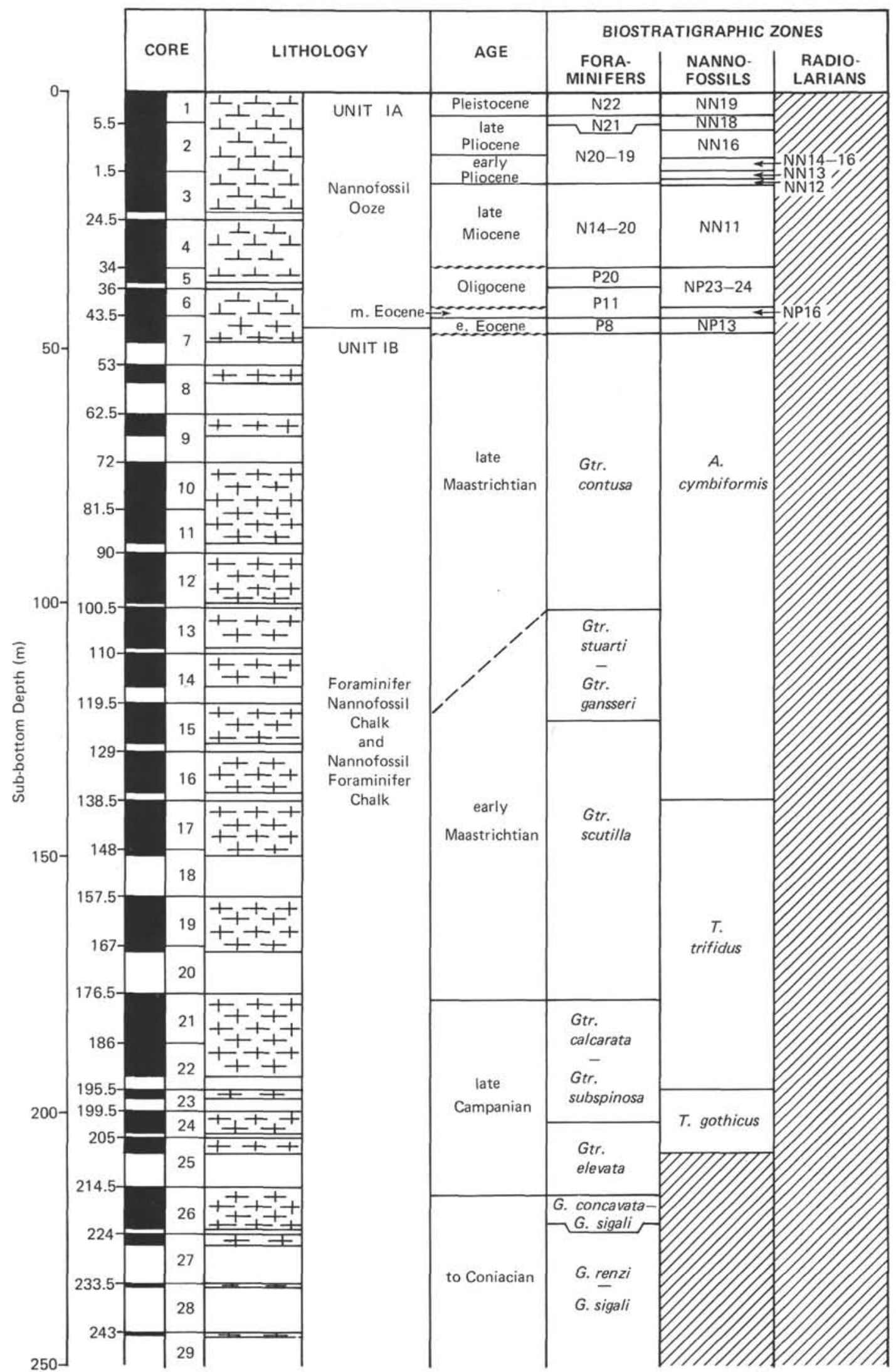

Figure 17. Bio-, litho-, and magnetostratigraphic summary of DSDP Site 463, on the western Mid-Pacific Mountains. 


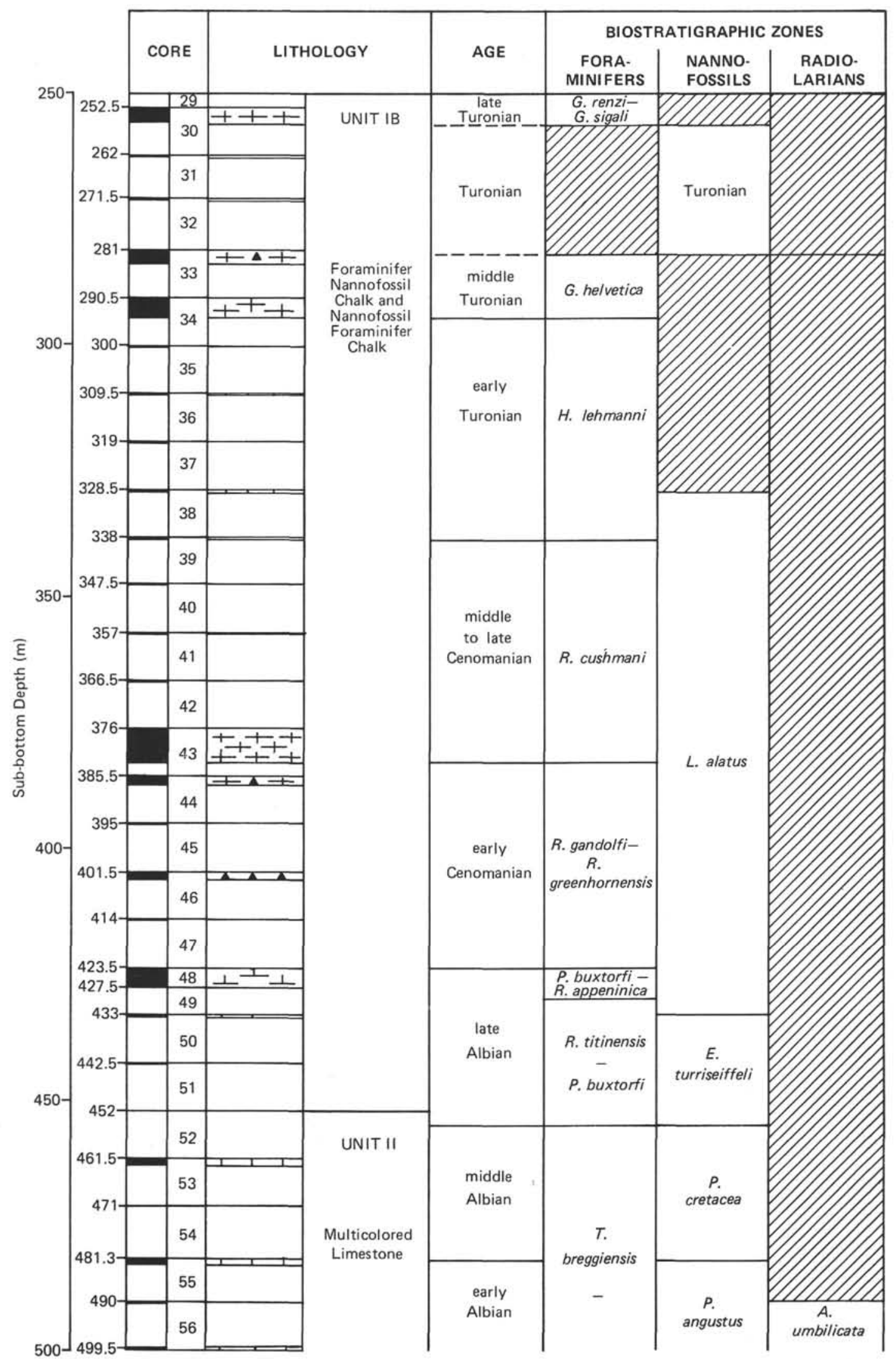

Figure 17. (Continued). 


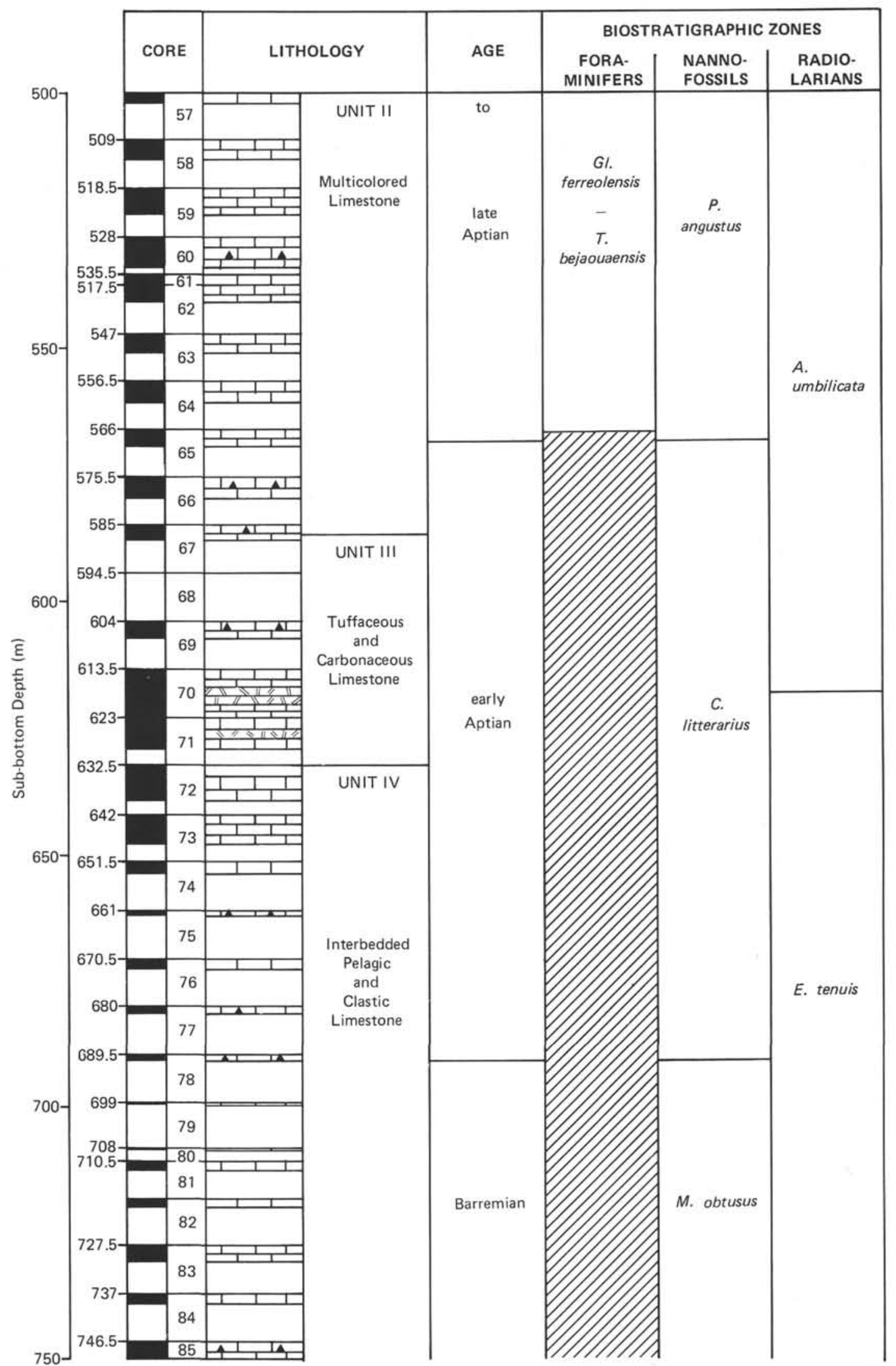

Figure 17. (Continued). 


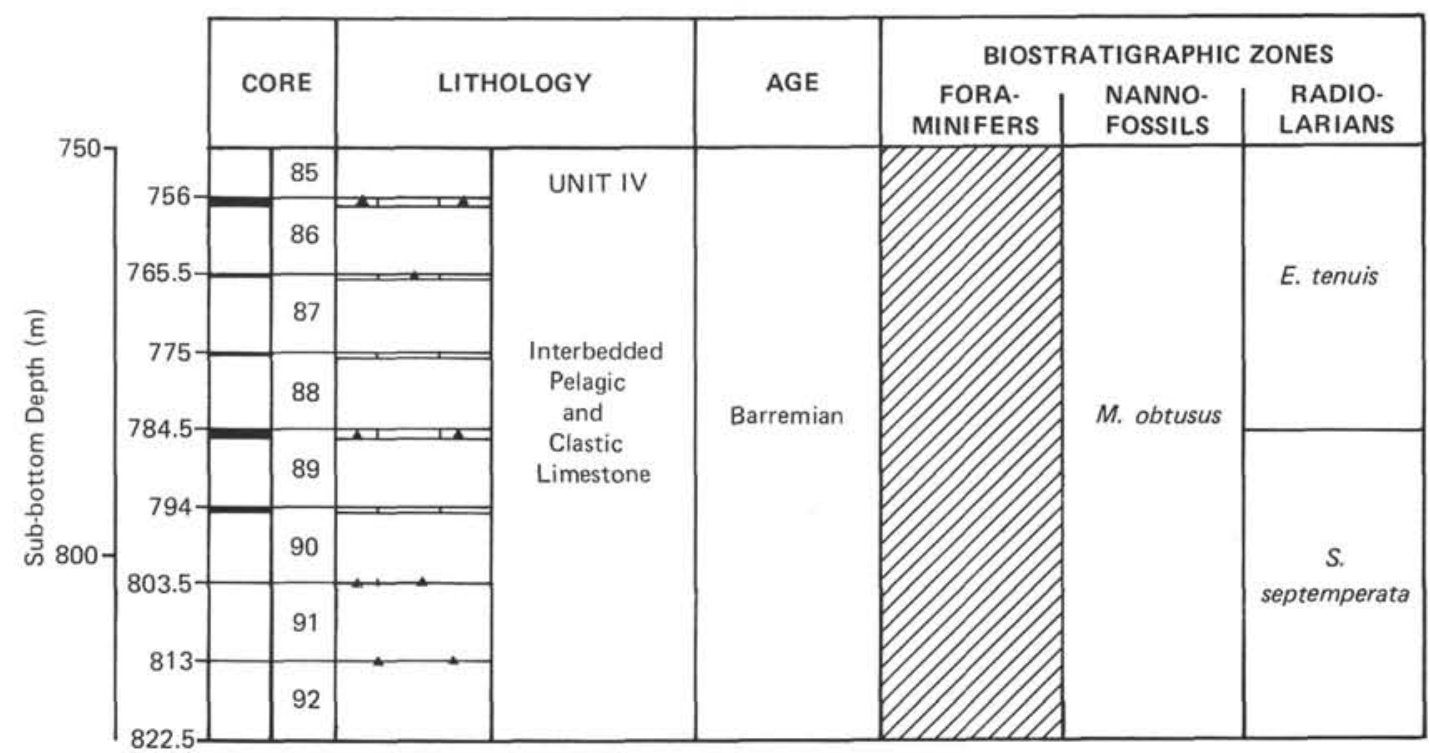

Figure 17. (Continued).

Site 463 . They are a very characteristic component of the sediment, but their abundance in the cored intervals changes frequently; they are often the cause for poor core recoveries. In general, their frequency is estimated not to exceed $5 \%$ of the bulk sediment (Hein et al., this volume). Cherts are known to be components intimately associated with pelagic sediments in the Pacific Ocean; their origin is believed to be linked (Lancelot and Larson, 1975) to the sedimentation of abundant opaline tests during times when the sites are located under fertile surface water masses. The opaline tests which formed the cherts of Site 463 were mostly deposited when the site was located under or close to the Cretaceous Equator (Fig. 14); however, they also occur in Eocene sediments of Site 463 , which were deposited when the site had moved to approximately $15^{\circ} \mathrm{N}$. The cherts of Site 463 formed by widespread nondestructive replacement of calcareous nannofossils by silica (Hein et al., this volume). Well-preserved burrows in many of the recovered cherts suggest that these burrows in the original, probably unconsolidated sediment were of particular significance for the path of movement and emplacement of the silica gels and for the formation of the chert. In places, a thin layer of porcellanite or quartz porcellanite clings to the upper and lower surface of the cherts.

\section{Paleogene and Neogene Calcareous Oozes}

The 47 meters of nannofossil ooze deposited at Site 463 during the Cenozoic accumulated slowly (Fig. 7) and represents a record of the depositional environment during a time when the Mid-Pacific Mountains subsided to their present water depths and when they had moved under the less-productive surface water masses of the subtropical North Pacific Ocean. The record is discontinuous because of long hiatuses. No sediments from this locality record the late Maastrichtian-early Eocene, Eocene-Oligocene, and late Oligocene-late Miocene intervals. The nannofossil ooze of this unit is dominantly pale brown to white, and therefore apparently was deposited under oxygenated intermediate waters-which is also supported by the intensive burrowing and mottling. Despite the homogeneous appearance of these oozes, we have found drastic compositional changes: the proportion of discoasters increases from approximately $30 \%$ of the bulk sediment in the upper Miocene deposits to more than $80 \%$ (maximum $98 \%$ ) in the Pliocene deposits (Fig. 26). The significance of this discoaster bloom - while most of the other plankton components disappeared-is presently not clear. In the Eocene deposits at the bottom of this unit, a few chert fragments of gray and brown colors were recovered. The chert must have formed when the site was already under the central subtropical North Pacific surface waters.

\section{Accumulation of Wind-Transported Inorganic, Nonvolcanic Sediments at Site $\mathbf{4 6 3}$}

Data on the mineralogy and mass-accumulation rate (MAR) of the inorganic fraction of sediments compiled from data presented elsewhere in this volume (Rateev et al.; Nagel and Schumann; Vallier and Jefferson; Rea and Janecek; Fig. 11) provide a general picture of the accumulation of that sedimentary component since Barremian time, about 118 m.y. ago. Much of the Cretaceous and Cenozoic section is dominated by illite, with lesser amounts of quartz, kaolinite, and chlorite. Because these minerals all have a continental source, and because Site 463 has always been shallower (Fig. 13) than the region below 4500 meters that is affected by nepheloid-layer deposition, the data of Figure 11 record in part the history of continentally-derived eolian deposition in the central Pacific Ocean, and they hence offer some information about atmospheric circulation. A back-track plot for Site 463 (Lancelot, 1978) shows (Fig. 14) that it has always been below either the southeast or northeast trade-wind system, suggesting that the American (and possibly African) continent was the source of the eolian materials.

All Cenozoic eolian materials are dominated by illite, as are most of the Cretaceous sediments younger than 


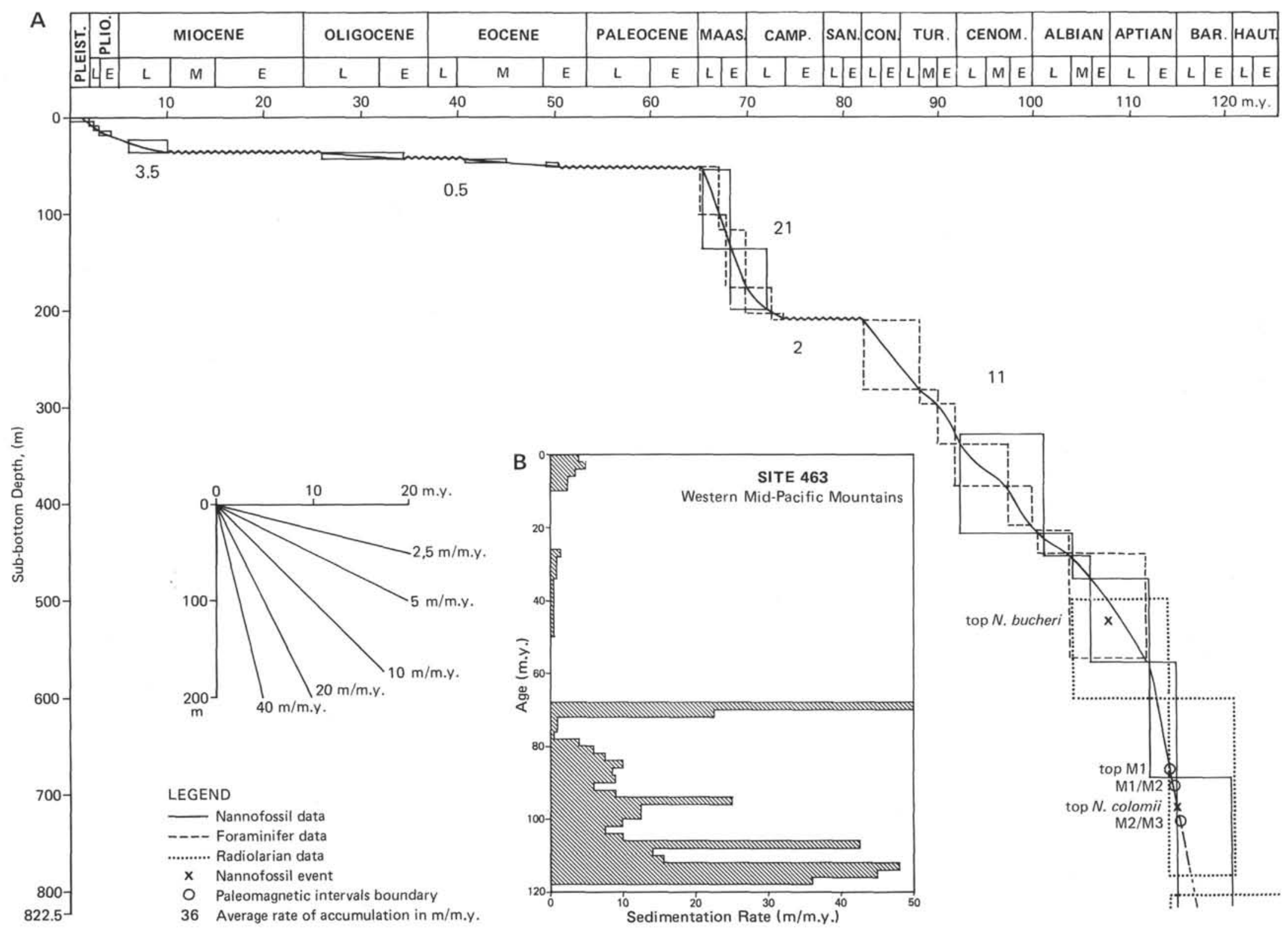




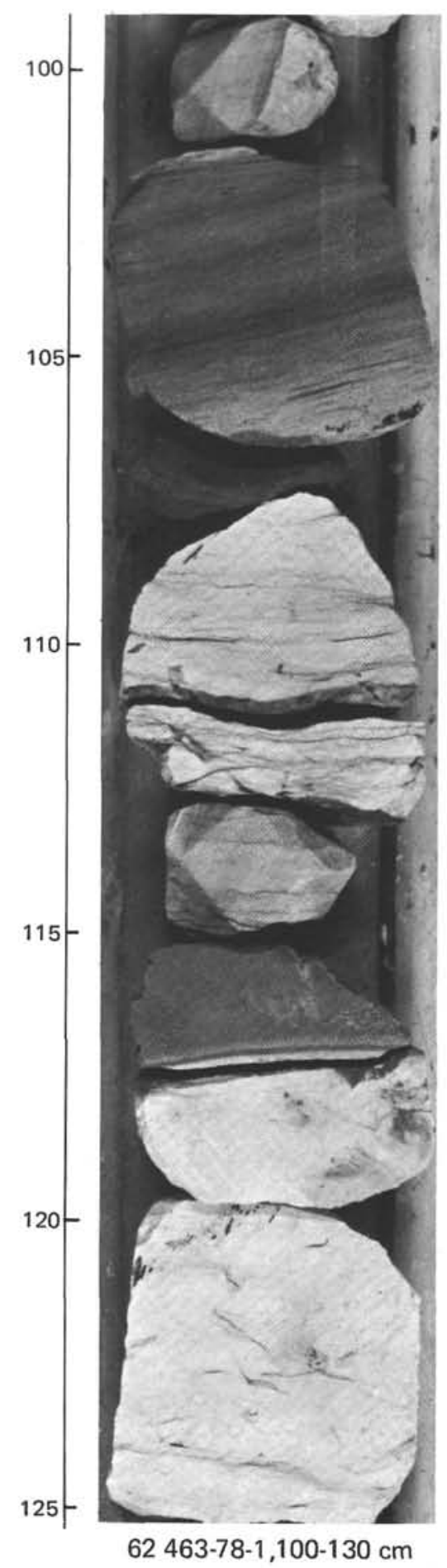

Figure 19. Pelagic limestones of Barremian age from Site 463. Note the volcanic-ash (bentonite) bed at $115-118 \mathrm{~cm}$.

Aptian-Albian age. A volcanogenic, smectite-dominated clay-mineral assemblage occurs in the lower Maastrichtian oozes and chalks. Within the Barremian through Aptian-Albian smectite-dominated sediments, a horizon of illite-dominated clay minerals of approximately early to middle Aptian age occurs (Fig. 11).

The mineralogy and MAR data suggest that there was always at least a moderate amount of land-derived ma- terial carried to the central Pacific prior to mid-Turonian time. In sediments older than Aptian-Albian age, this component is usually subordinate to the volcanogenic materials derived from much closer sources. The early to middle Aptian horizon of illite-dominated clays has a MAR of about $0.5 \mathrm{~g} \cdot \mathrm{cm}^{-2} \cdot 10^{-3} \mathrm{yr}^{-1}$ (Fig. 11). In the Late Cretaceous, the MAR of continental eolian material decreased from $0.45 \mathrm{~g} \cdot \mathrm{cm}^{-2} \cdot 10^{-3} \mathrm{yr}^{-1}$ in the early Albian to $0.1 \mathrm{~g} \cdot \mathrm{cm}^{-2} 10^{-3} \mathrm{yr}^{-1}$ by the late Albian, and then increased again to $0.34 \mathrm{~g} \cdot \mathrm{cm}^{-2} \cdot 10^{-3} \mathrm{yr}^{-1} \mathrm{dur}-$ ing the Cenomanian. Accumulation rates decreased from Cenomanian to about mid-Turonian time, and very low MAR values of $0.01 \mathrm{~g} \cdot \mathrm{cm}^{-2} \cdot 10^{-3} \mathrm{yr}^{-1}$ continued from mid-Turonian through Campanian time. Maastrichtian MARs are complicated by the volcanic input, but the data suggest an increase in continental eolian input near the end of the Maastrichtian record of Site 463.

Data for Cenozoic eolian input are sparse. Mineralogies of clays suggest that continental sources continued to dominate the eolian fraction, and the MARs are generally low, never exceeding $0.05 \mathrm{~g} \cdot \mathrm{cm}^{-2} \cdot 10^{-3} \mathrm{yr}^{-1}$. Rea and Janecek (this volume, their fig. 4) provide details of the upper Miocene to Recent eolian MAR. Upper Miocene values are low, less than $0.01 \mathrm{~g} \cdot \mathrm{cm}^{-2}$. $10^{-3} \mathrm{yr}^{-1}$. A maximum of about $0.03 \mathrm{~g} \cdot \mathrm{cm}^{-2} \cdot 10^{-3} \mathrm{yr}^{-1}$ occurred during the early Pliocene, followed by a late Pliocene low of $0.01 \mathrm{~g} \cdot \mathrm{cm}^{-2} \cdot 10^{-3} \mathrm{yr}^{-1}$. From about 3 m.y. ago through the Pleistocene, the eolian MAR increased by about a factor of 5 to a maximum of 0.048 $\mathrm{g} \cdot \mathrm{cm}^{-2} \cdot 10^{-3} \mathrm{yr}^{-1}$.

The late Cenozoic eolian accumulation pattern at Site 463 is similar to that found elsewhere in the North Pacific, at DSDP Site 310, and in piston core LL-44GPC-3 recovered by the University of Rhode Island about $1000 \mathrm{~km}$ north of Hawaii. The two maxima in eolian MAR appear to record (1) the early Pliocene volcanic maxima related to both circum-Pacific (Kennett et al., 1977) and mid-plate (Rea and Scheidegger, 1979) volcanoes, and (2) the late Cenozoic climatic deterioration and onset of the glacial ages (Rea and Janecek, 1980).

The land-derived eolian input is a function of both source availability and of wind intensity. The latitudinal temperature gradient during the Cretaceous appears not to have changed much, suggesting that the intensity of the winds may have remained generally constant for that time. The vast Cretaceous transgressions and regressions, however, would have significantly altered the source availability of eolian material. Thus, the Late Cretaceous eolian MAR might be expected to record this phenomenon, times of maximum transgression corresponding to the lowest eolian MAR.

Vail et al. (1977) have presented sea-level curves illustrating the general timing and degree of transgressions and regressions during Mesozoic and Cenozoic time. Their data show a Hauterivian to mid-Aptian transgression, followed by a sharp, brief regression, then a second transgression, continuing to Cenomanian time. Another regression occurred during the latter Cenomanian, followed by a transgression that continued until the middle Turonian. The ensuing $25 \mathrm{~m}$.y., from mid-Turo- 


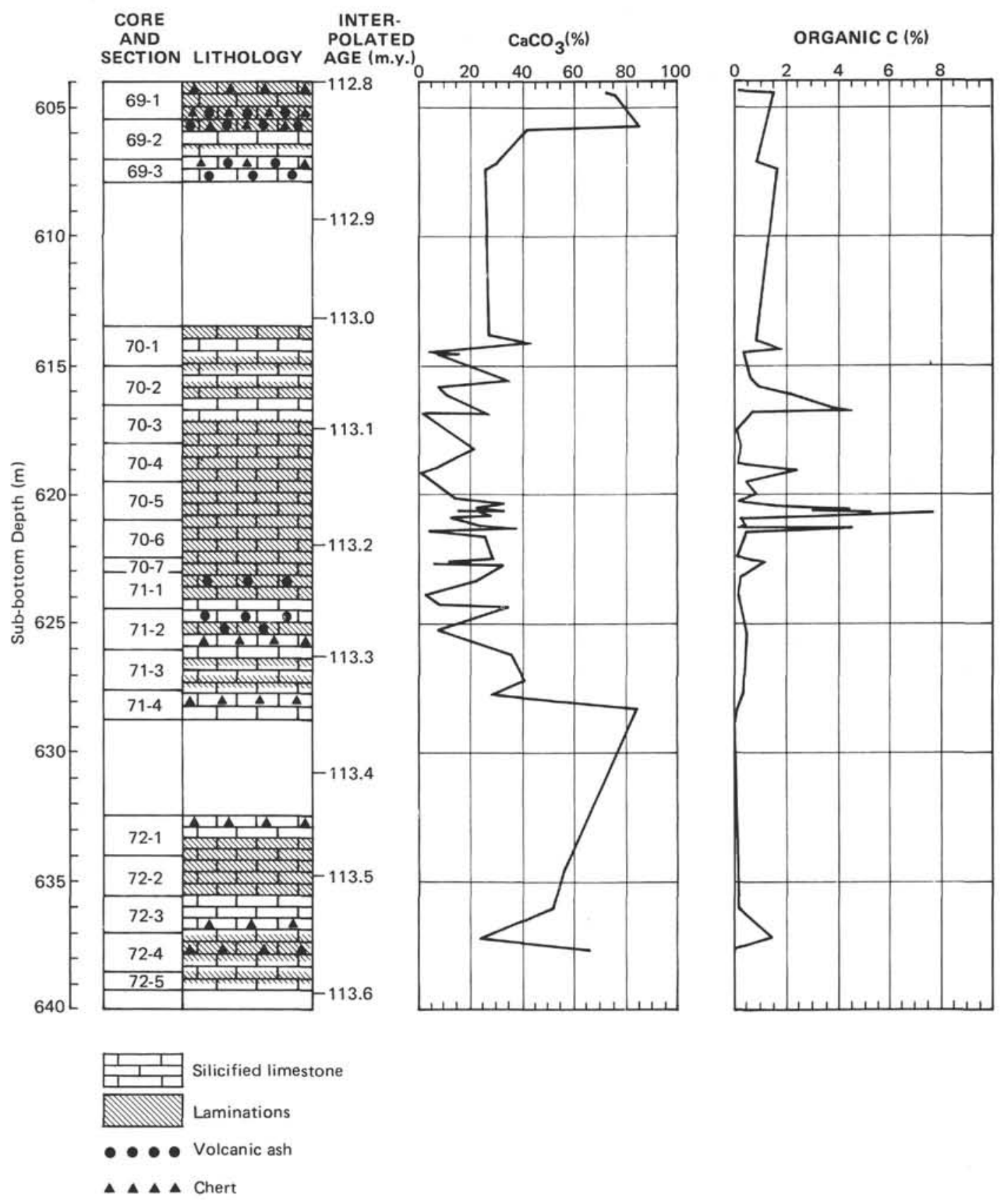

Figure 20. Lithology, calcium carbonate, and organic-carbon concentrations of the "black shale"-bearing Aptian interval at Site 463.

nian through Maastrichtian time, was a period of constant, widespread epicontentintal seas that remained until the late Maastrichtian-Paleocene regression (Vail et al., 1977, their fig. 2).

The temporal pattern of land-derived eolian MAR at Site 463 (Fig. 11) matches these sea-level fluctuations remarkably well. The early to mid-Aptian horizon of illite-dominated material occurs at the time of the sharp mid-Aptian regression. During Albian to Cenomanian time, the falling eolian MAR reflects the transgression of the same age. The mid-Cenomanian regression is reflected by another peak in eolian MAR, and the reduction in accumulation from that time to the mid-Turo- nian and continuing low values correspond to the Cenomanian-Turonian transgression and ensuing highstand.

The sea level and eolian MAR data fit together well. The actual mass flux of eolian material to the oceans during the Cretaceous is, however, surprisingly high, averaging about $0.28 \mathrm{~g} \cdot \mathrm{cm}^{-2} \cdot 10^{-3} \mathrm{yr}^{-1}$ from Albian to early Turonian time. This value is similar to the maximum recorded MAR of eolian sediment during the Pleistocene glaciations at DSDP Site 310 on Hess Rise and LL-44-GPC-3 north of Hawaii (Rea and Janecek, 1980). Additionally, Site 463 was several thousand kilometers farther from the land source during the Cretaceous than those more northerly sites are from present 


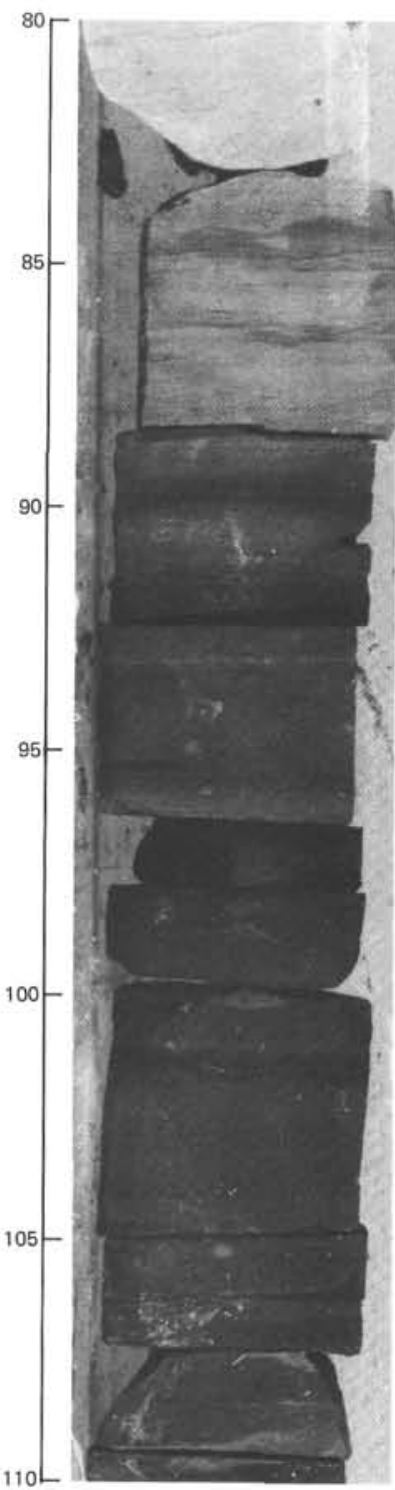

$62463 \cdot 70 \cdot 5,80-110 \mathrm{~cm}$

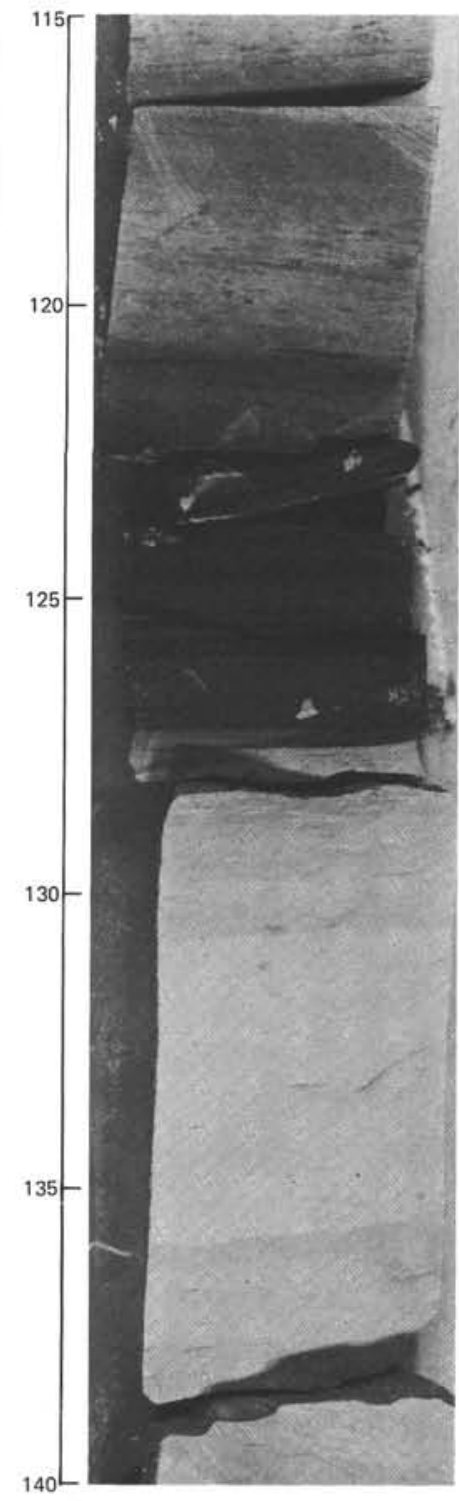

$62463-71-1,115-140 \mathrm{~cm}$

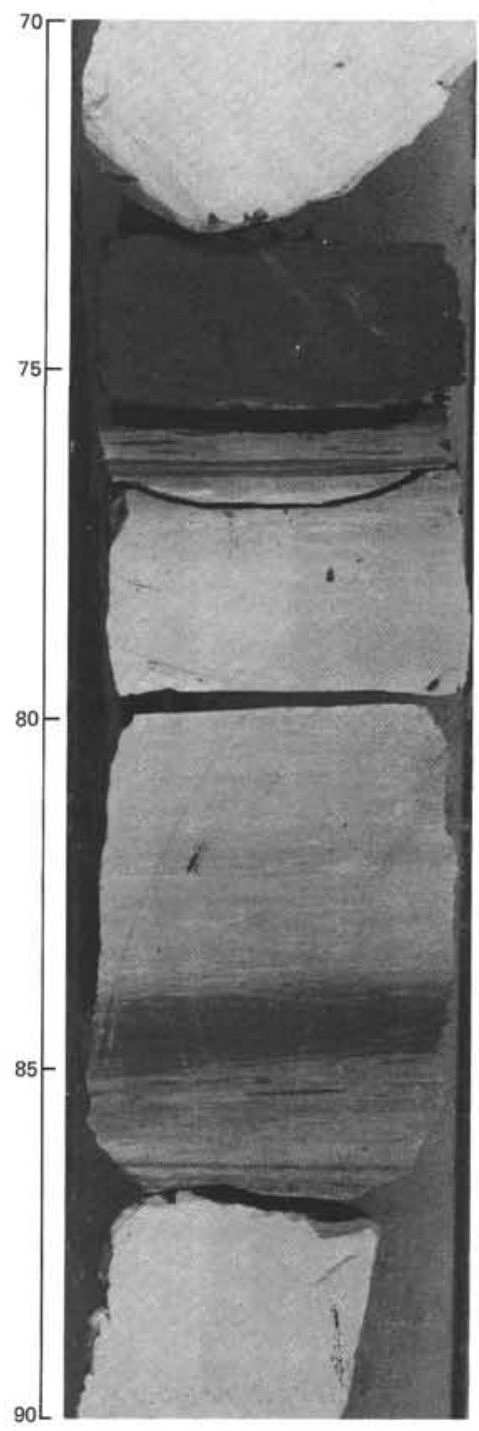

62 463-67-2, 70-90 cm

Figure 21. Selected photographs of core from the "black-shale"-bearing Aptian interval of Site 463.

sources (Firstbrook et al., 1978). Taken together, this information suggests that the mid-Cretaceous may have been a relatively dry and dusty time.

\section{Reworking in the Cretaceous and Cenozoic Central Pacific}

The impacts of the oceanic surface water and of the atmospheric circulation on sedimentation on the western Mid-Pacific Mountains during the past 120 m.y. have already been discussed. However, bottom-water currents can remobilize the sediments once they are deposited, and the results from Leg 62 indicate that the intensity of the bottom-water currents have changed drastically in Cretaceous and Tertiary times. Hiatuses in sedimentary columns in the ocean, for example, can document erosion. However, in places, apparently homogeneous deep-sea sediments also contain reworked and displaced contemporaneous and noncontemporane- ous older fossils. These occurrences document erosion and mechanical transport which remobilized neritic and pelagic sediments. Aspects of reworked material in central Pacific Ocean deep-sea sediments are discussed in detail elsewhere (Thiede et al., this volume).

Reworked fossils were found in the sedimentary columns of three of the four DSDP drill sites in the MidPacific Mountains. At Site 171, reworked, contemporaneous, shallow-water fossils occur in Cenomanian and upper Campanian deposits; planktonic fossils of early Eocene to Maastrichtian age are incorporated in the middle Eocene chalks. Reworked planktonic fossils of uncertain age were observed in lower middle and upper middle Miocene and Quaternary nannofossil ooze of Site 313.

Reworked and displaced sediment components have been found both in the Mesozoic and Cenozoic parts of the sedimentary column at Site 463 . The different pres- 


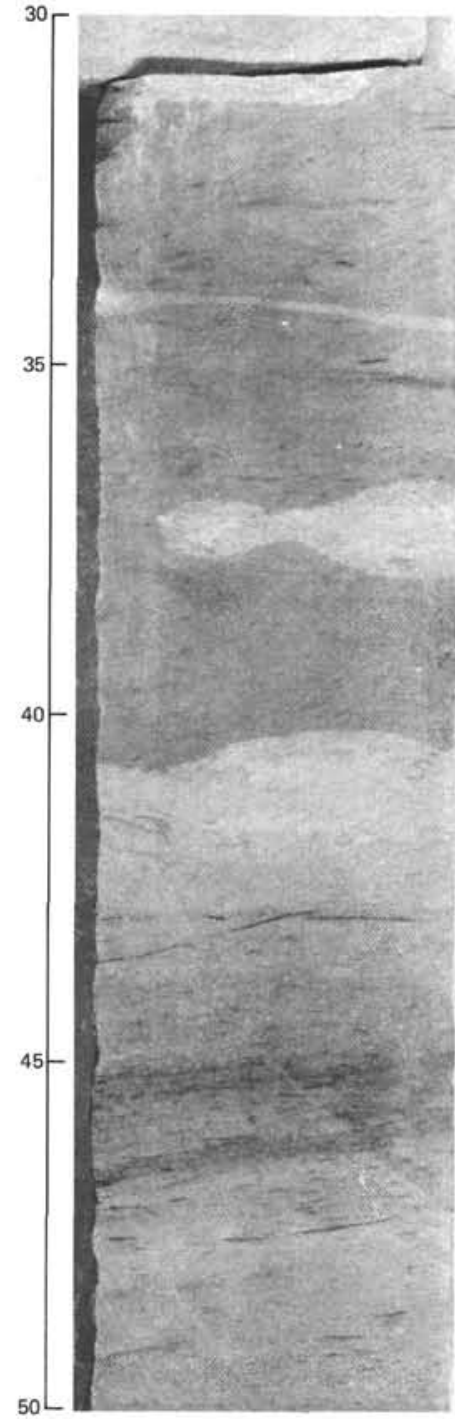

$62463 \cdot 71-2,30-50 \mathrm{~cm}$

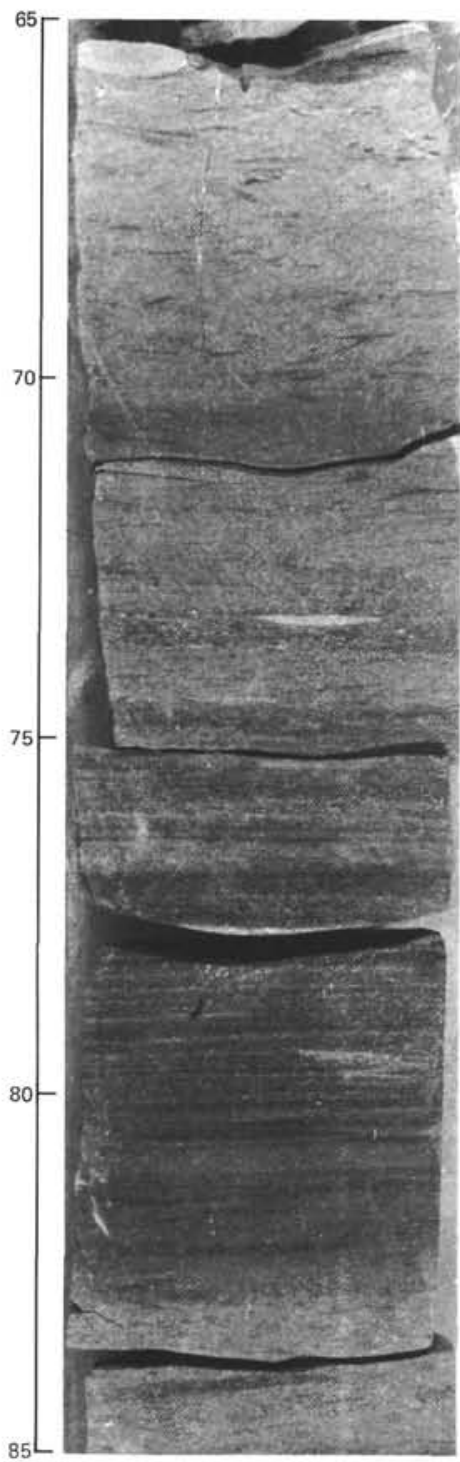

$62463-71 \cdot 2,65-85 \mathrm{~cm}$

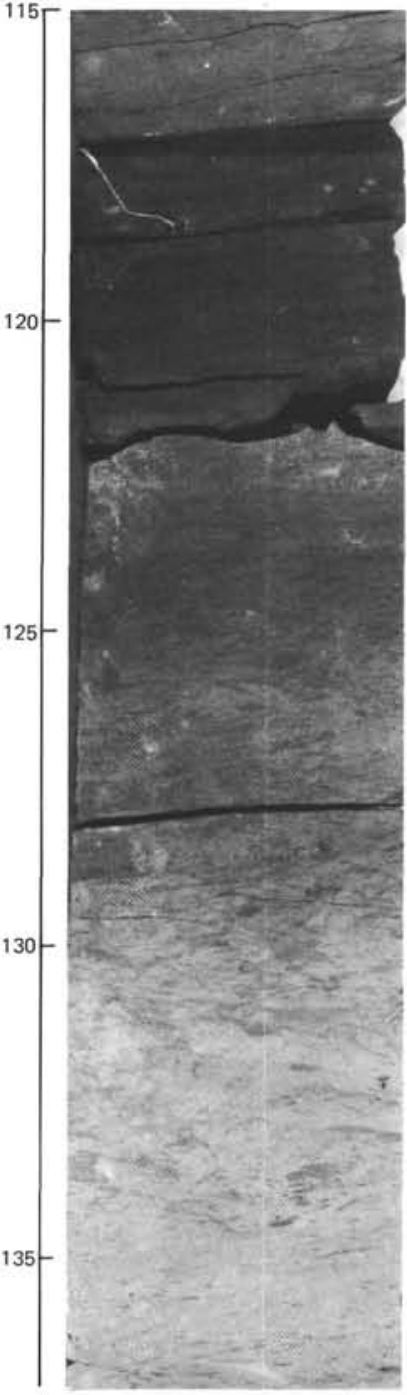

$62463 \cdot 70-1,115-137 \mathrm{~cm}$

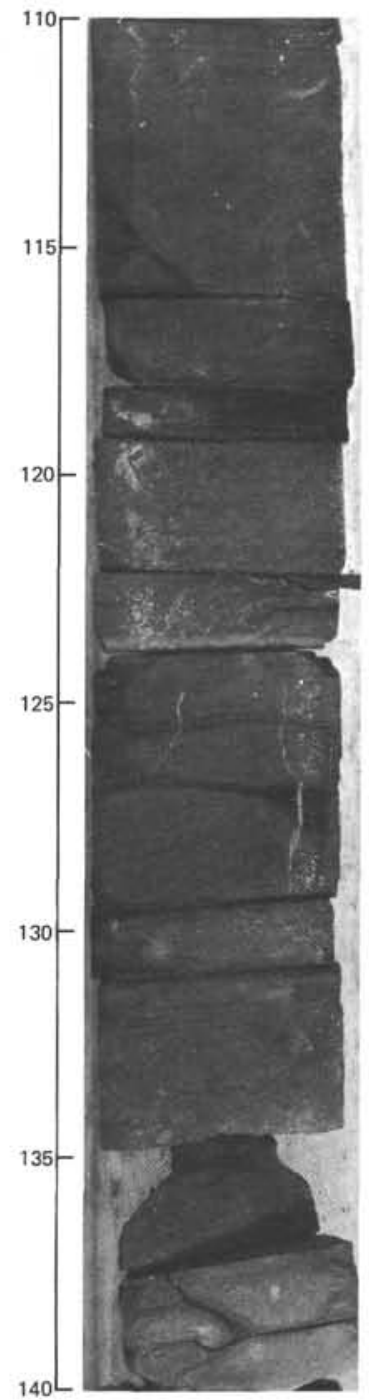

$62463 \cdot 70 \cdot 5,110-140 \mathrm{~cm}$

Figure 21. (Continued).

ervational stages of radiolarian skeletons, the low-diversity assemblages, the sorting of abundant and wellpreserved spherical tests, and the fragmentation of all nassellarian tests suggest displacement of coeval radiolarian faunas during the Barremian. Middle Miocene to Cretaceous planktonic foraminifers occur in Core 4 (upper Miocene). Pliocene calcareous nannofossils occur in the Quaternary sediments of Cores 1 and 2, Miocene to Eocene forms occur in Core 4 (upper Miocene), and Eocene forms occur in Core 6 (Oligocene). Displaced shallow-water components include large benthonic foraminifers in Cores 8-12, 16, 20, 22, 23, 37, 38, and 49. The interbedded clastic limestones of lithologic Unit IV (Fig. 27) are composed of shallow-water carbonates which contain oolites, mollusk and echinoderm fragments, stromatolites and algal fragments, and large foraminifers (Ferry and Schaaf, this volume).

A survey (Thiede et al., this volume) of the data from other deep-sea drill holes in the central Pacific Ocean demonstrates that reworked sediment components are common at many locations. The sites from which these observations were collected cover the entire western subtropical and tropical Pacific Ocean, whose sea floor is dominantly of Jurassic, Cretaceous, and early Tertiary age. Because of the widespread regional distribution of the drill sites of such a wide area, a bias toward a single deep-sea basin or toward a very specialized depositional environment can be excluded.

The occurrence and age distribution of shallowwater-derived displaced sediment components (Fig. 28) at many deep-sea drill sites of the western central Pacific Ocean was unexpected, because these sites are at a distance from extensive land areas; however, it has been known for some time that many of the submarine rises and platforms in the western central Pacific Ocean were close to or above the sea surface. Because shallow-water carbonate rocks have been dredged from their flanks (Hamilton, 1956; Matthews et al., 1973) at water depths 


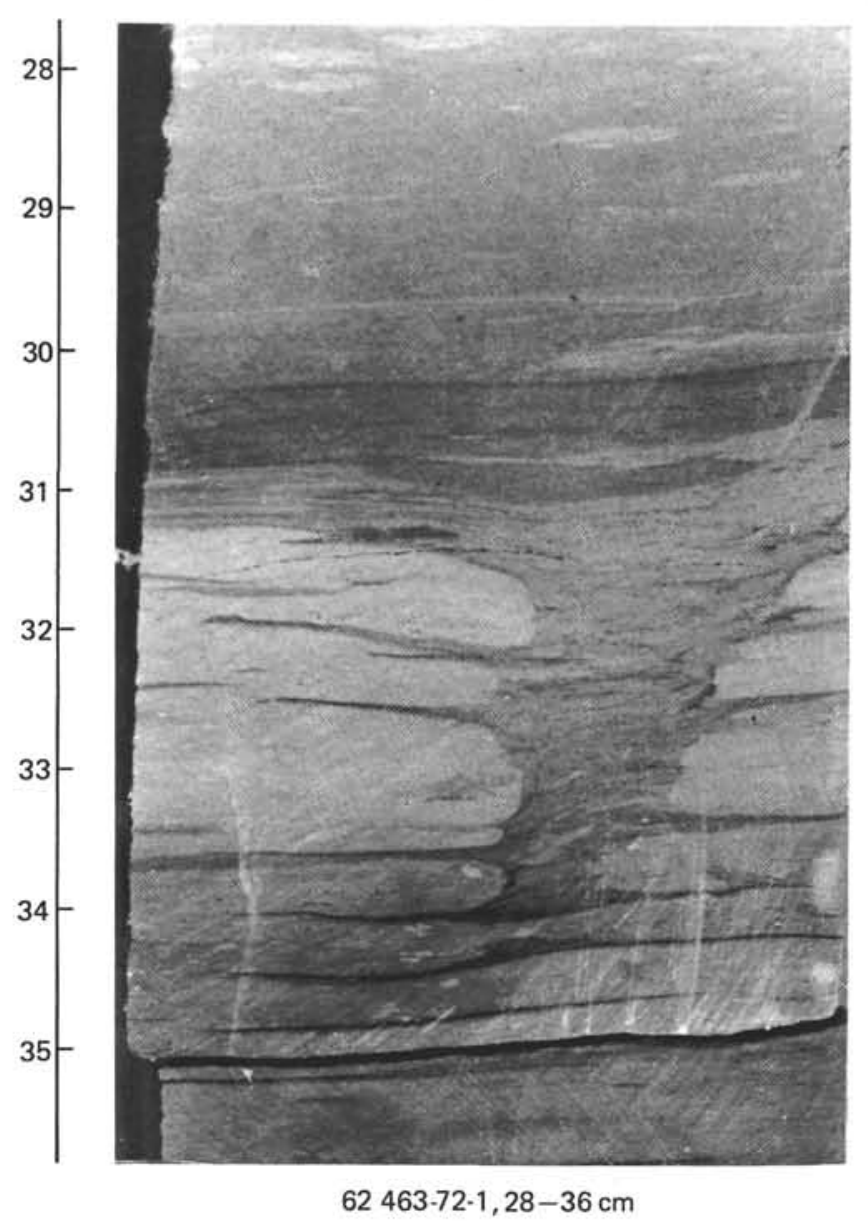

Figure 22. Large burrow close to the "black shales" of Site 463.

of several hundred to several thousand meters (Heezen et al., 1973), these structures may have served as sources for such displaced material. Evidence for displacement of shallow-water carbonate fossils from their original depositional environment into the adjacent deep-sea is temporally and spatially widespread (Fig. 28). Most of the occurrences document the displacement of sediments of approximately the same age as the host sediment, whereas evidence for erosion cutting into sections considerably older than the time of displacement has been found only in very few instances. These sites are close to the Tuamotu Islands, close to the Line Islands, close to the Emperor Seamounts, and in the Nauru Basin-exclusively in Cenozoic sediments, and in areas where extensive reworking of shallow-water sediments has been recorded in deep-sea drill sites (Fig. 28). The maximum difference between the age of the reworked material and the time of displacement is $>50$ m.y. in late Oligocene deposits of Site 462 in the Nauru Basin (Schlanger and Premoli Silva, 1981).

Contemporaneous, shallow-water-derived carbonate fossils have been observed in sediments ranging from Barremian-Aptian to Quaternary in age. They are not evenly distributed through time, but seem to prefer specific time spans. The earliest event has been observed in the Barremian-Albian, and the next in the Cenoma- nian. Intensive displacement of shallow-water carbonates took place during Campanian and Maastrichtian time, but decreased sharply toward the Cretaceous/Tertiary boundary. The Paleocene deposits have not produced evidence of reworked shallow-water carbonates in the central Pacific Ocean, but this might be the result of many and extensive hiatuses over this interval, which developed during a time of deep-sea erosion. During the Cenozoic, the flux of shallow-water components was particularly important in the early Eocene, late Eocene, late Oligocene, late Miocene and Plio-Pleistocene (Fig. 28). It seems particularly notable that the influx of shallow-water-carbonate fossil debris during the entire time span considered here occurred in pulses, and that it rather represented a sequence of episodic events than a continuous process.

The distributional patterns of reworked and displaced fossils produced by the oceanic plankton (Fig. 29) are very different from those of fossil debris derived from shallow-water regions, but they have also been found in numerous drill sites in the central Pacific Ocean. Displaced pelagic fossils (Fig. 29) include all four major pelagic microfossil groups (diatoms, radiolarians, coccoliths, foraminifers), whose grain-size spectra range from silt- to sand-sized material. Most occurrences $(\sim 80 \%)$ are of reworked coccoliths and planktonic foraminifers, and a minor number are reworked radiolarians. The information is therefore biased toward the depositional environments of calcareous oozes above the CCD and under the influence of meso- and bathypelagic water masses (Reid, 1965), but not the deepest water masses.

Although we know from textural studies that the surface sediments of the modern ocean are intensively reworked, this cannot be documented as easily for older ocean floors. Even though sedimentary structures in deep-sea drill cores often indicate bottom-water currents, the amount of reworking and displacement of contemporaneous biogenic components is difficult to detect and to assess; however, if noncontemporaneous reworked fossils are considerably older than the deepsea sediments in which they occur, they can be used as an unequivocal argument for mechanical current transport. The properties of the eroded sediments and of the transported sediment particles are evidence for the strength of the reworking currents. In Figure 29, we plotted only observations of noncontemporaneous reworked fossils, some of which can be as much as 70 m.y. older than their host sediment. The most surprising feature of the distributions of reworked noncontemporaneous pelagic fossils in the central Pacific Ocean (Fig. 29 ) is the almost complete lack of such redeposited pelagic fossil material in most of the Mesozoic parts of the penetrated sections. The earliest occurrences were observed in Maastrichtian sediments, but the number of observations remains modest until the upper middle Eocene, where a major episode of erosion in the mesoand bathypelagic water masses of the central Pacific Ocean is reflected. Therefore, the planktonic-foraminifer faunas of many sites bear ample evidence of wide-spread reworking of Eocene to Cretaceous faunas 
(Krasheninnikov, this volume). The past $40 \mathrm{~m} . \mathrm{y}$. has been a time of constant reworking of deep-sea sediments, with peaks of erosion approximately 40,30 to 32,14 to 15,7 to 8 , and 0 to $5 \mathrm{~m}$.y. ago. The number of observations from the intervals 10 to 13,15 to 25 (in particular), and 33 to $38 \mathrm{~m} . \mathrm{y}$. ago is relatively small, indicating relatively quiescent bottom-water movements.

The difference between the age of the eroded section and time of final deposition of the reworked material obviously can range over a wide time span, and the precision of this variable is very dependent upon the detail of available stratigraphic data. In this context, it has to be kept in mind that the biostratigraphic zonations of Mesozoic deep-sea sediments are considerably less refined (van Hinte, 1976) than the Cenozoic zonations (Berggren and Van Couvering, 1974; Hardenbol and Berggren, 1978). It is therefore obvious that the Mesozoic and Cenozoic data from the central Pacific Ocean cannot be compared easily. The age difference can in general range from 0 (reworking of contemporaneous or penecontemporaneous deposits) and a maximum value which is determined by the difference in age of the oldest eroded sediments and the time of deposition of the reworked components. It seems to be characteristic of the central Pacific Ocean that there is apparently no age difference between reworked and host sediments in most of the penetrated Mesozoic section, and that only coeval sediments have been reworked. Only after Maastrichtian time, when fossils from upper Campanian deposits were incorporated into the chalks and calcareous oozes, did a major age difference begin to develop. The maximum age difference between oldest reworked fossil components and host sediment increased in a regular fashion from the Maastrichtian to approximately $38 \mathrm{~m} . y$. ago, in late Eocene time, when the age difference reached 30 to $40 \mathrm{~m}$.y. Between the late Eocene and late Pliocene to early Pleistocene, the maximum age difference fluctuated between 20 and $70 \mathrm{~m} . \mathrm{y}$. High age differences were reached in late Eocene and early Oligocene time, during the early to middle Miocene, and at the end of the Pliocene, whereas minimal values are confined to times when the number of observations of reworked pelagic material in general was reduced. A drastic decrease of the maximum difference in age of the reworked sediment components and the host sediment during the early and late Pleistocene, which already had been observed at Site 462 in the Nauru Basin (Rea and Thiede, 1981), can also be seen in the data collected here and seems to be a general feature of the redeposition of older pelagic deposits in the central Pacific Ocean.

\section{DISSOLUTION OF PELAGIC SEDIMENT COMPONENTS ON THE MID-PACIFIC MOUNTAINS, AND HIATUSES IN THE CENTRAL PACIFIC OCEAN}

Both calcareous and opaline skeletal material produced by benthic and planktonic organisms often are subject to dissolution, owing to dissolution on the ocean floor, or to diagenetic processes. Diatoms have not been observed in Site 463 sediments. Radiolarians are very scarce in Albian to Quaternary deposits, but they occur commonly and are commonly well preserved in the lowermost part of the Cretaceous section of Site 463. The abundance of chert, mainly in the Cretaceous, but also in the Eocene deposits, suggests that the sediments originally received large quantities of opaline skeletal material, but that most of this material has been altered to chert.

It has been established previously that during the past $120 \mathrm{~m}$.y. the sea floor at Site 463 was situated in shallow to intermediate water. Hence, it always resided well above the late Mesozoic and Cenozoic CCD (van Andel, 1975; Thierstein, 1979). Despite this fact, we have observed numerous indications of intensive dissolution of $\mathrm{CaCO}_{3}$ in the sedimentary column of Site 463 . This is particularly evident in the condensed Neogene section, where planktonic foraminifers are fragmented and poorly preserved, and where the upper Miocene to $\mathrm{Re}$ cent nannofossil floras are slightly etched. The dominance of discoasters in upper Miocene and Pliocene sediments might also result from differential dissolution. The calcareous fossil assemblages are better preserved in the Paleogene and Cretaceous sediments than in the younger deposits of this site, but with increasing sub-bottom depth they are increasingly affected by recrystallization. Stylolitic seams in the oldest rocks also indicate various degrees of diagenetic dissolution. The condensed nature of the Tertiary sequence of this site prevented us from studying the dissolution cycles of the calcareous material found on Hess Rise (cf. Vincent, this volume).

Important hiatuses were detected in the Cenozoic part of the Site 463 sedimentary column (Fig. 7). They represent Maastrichtian to early Eocene, Eocene to Oligocene, and late Oligocene to late Miocene intervals. Hiatuses representing similar time spans also have been observed at the drill sites on the eastern Mid-Pacific Mountains, and therefore they have some regional importance (see also Timofeev et al., this volume). The hiatuses seem to have been generated by a combination of mechanical and chemical erosional processes, and it is presently not clear which one was the dominating factor. The patterns of reworked material (see above) seem to suggest that mechanical erosion played an important role at intermediate water depths throughout the Cenozoic; however, sediments deposited on the ocean-basin floor adjacent to the structural highs have, because of the water depths, almost certainly been severely affected by dissolution.

These observations prompted a preliminary survey of the paleodepth and age distribution of major hiatuses in the central Pacific Ocean (Fig. 30). Only sites where substantial, relatively complete coring records have been obtained and whose subsidence could be reconstructed with reasonable certainty have been included in this analysis; the combination of these two prerequisites eliminated most of the basin sites. However, despite the incomplete nature of the data displayed on Figure 30, it is clear that hiatuses are randomly distributed neither with respect to time nor to paleodepth. The most outstanding feature of this diagram is the frequency of hiatuses across the Cretaceous/Tertiary boundary, which affected almost all investigated depth intervals (excep- 


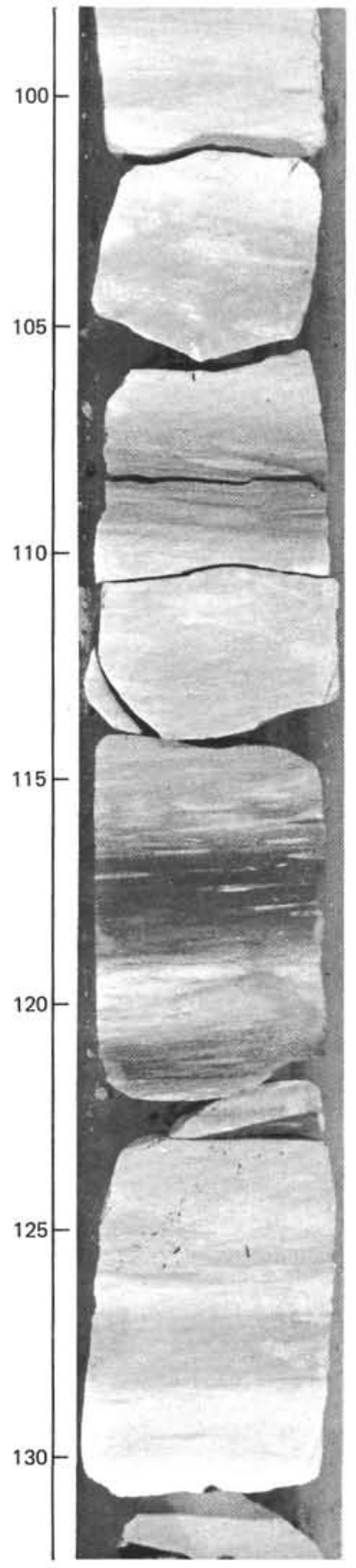

62 463-62-1, 100-130 cm

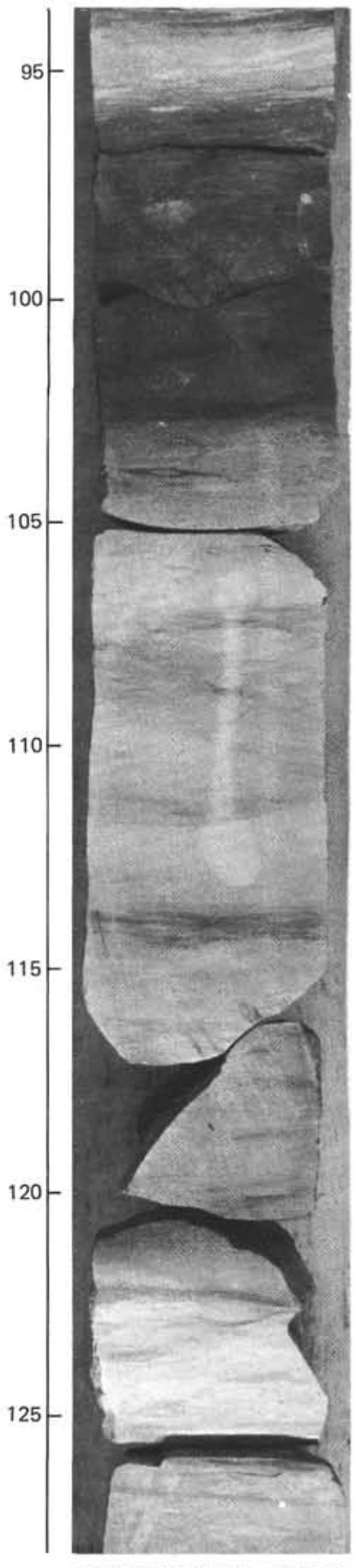

62 463-61-1, 95-125 cm

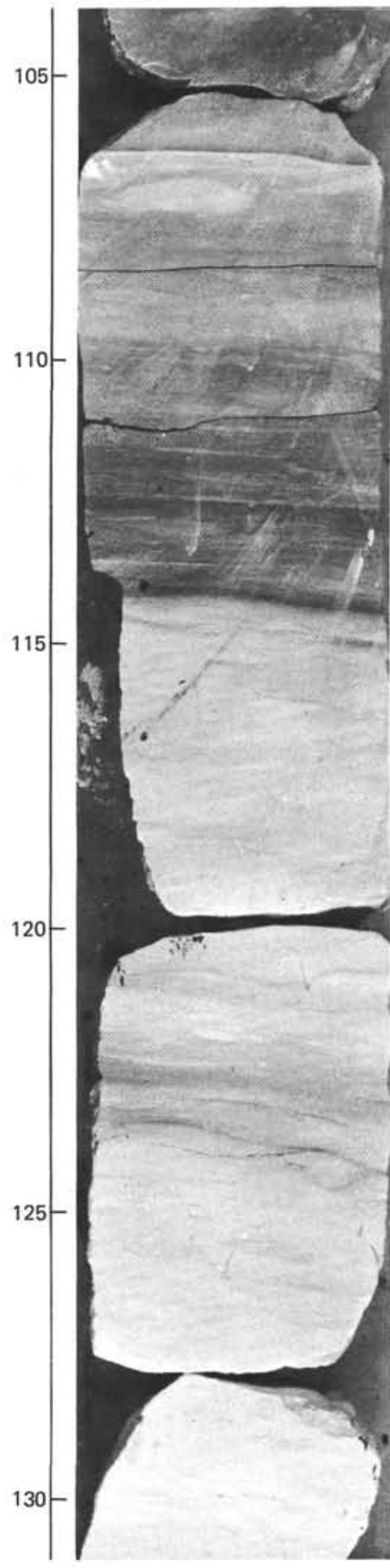

62 463-59-3, 105-130 cm

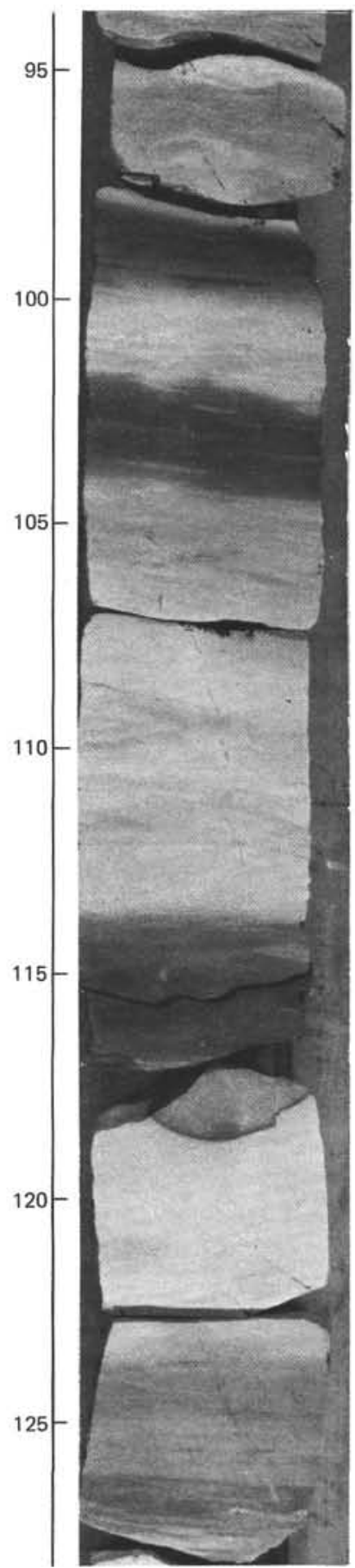

62 463-59-2, 95-125 cm

Figure 23. Examples of cyclic color variations in the Aptian-Albian multicolored limestones of Site 463. Colors are various hues of reddish-gray, greenish-gray, greenish-black, gray, brown, green, and white.

tion, Site 465). Most of them are overlain by Paleocene to lower Eocene sediments, and most did not cut very deeply into the underlying Cretaceous sections. The Cenozoic sediments frequently revealed hiatuses which cluster around a paleodepth interval of 2 to $3.5 \mathrm{~km}$ (intermediate water depth), and they have also affected depth intervals deeper than 4.5 to $5 \mathrm{~km}$, but most of them seem to be absent from the 3.5 to $4.5 \mathrm{~km}$ depth interval. Remarkably, the Mesozoic sections rarely re- vealed hiatuses, in contrast to the Cenozoic sections. Figure 30 indicates that hiatuses result from episodic paleoceanographic events which affected only well-defined depth intervals (or water masses) in the ocean.

\section{DIAGENESIS OF MID-PACIFIC MOUNTAINS SEDIMENTS}

The lithologic subdivision of sedimentary columns into (Cenozoic) oozes and (Mesozoic) chalks and lime- 


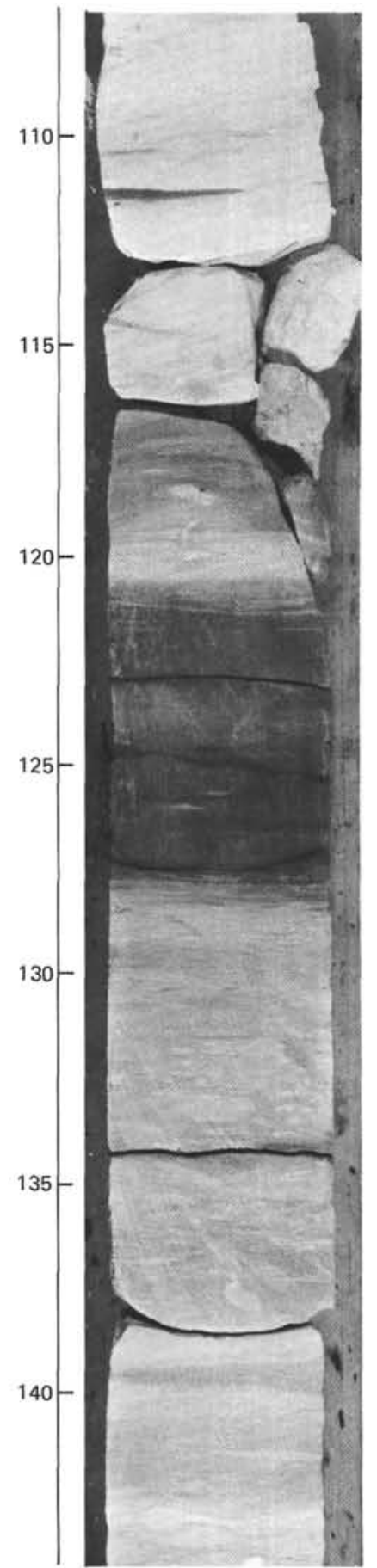

62 463-66-2, 110-142 cm

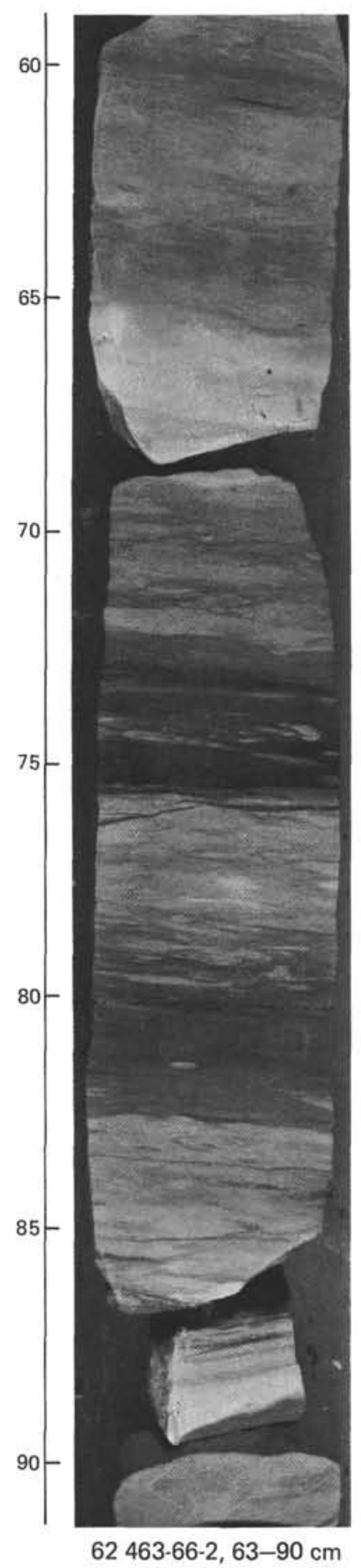

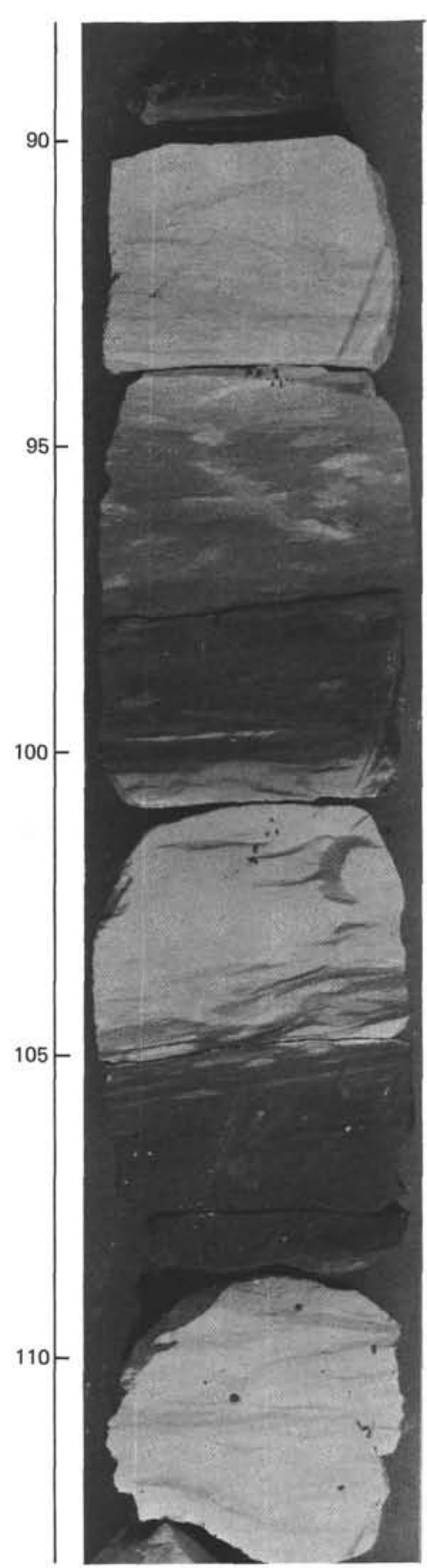

62 463-63-1, 90-110 cm

Figure 23. (Continued).

stones has been found at many sites on the aseismic rises in the central Pacific Ocean. Our observations of the distributions of hiatuses, reworked sediment components, and the three-dimensional preservation of burrows in cherts seem to indicate that these diagenetic changes have been relatively independent of depth of burial, but that they occurred shortly after deposition of the sediments and over a wide area at the same time.
Hence, the diagenetic change of these sediments seems to point to fundamental changes of their environment of deposition, and maybe their primary composition, since Cretaceous time.

The most striking feature of the limestones in Lithologic Units II, III, and IV in Hole 463 is the extreme variability in the degree of silicification. This can be seen in the variations in $\mathrm{CaCO}_{3}$ concentrations $(<10-$ 

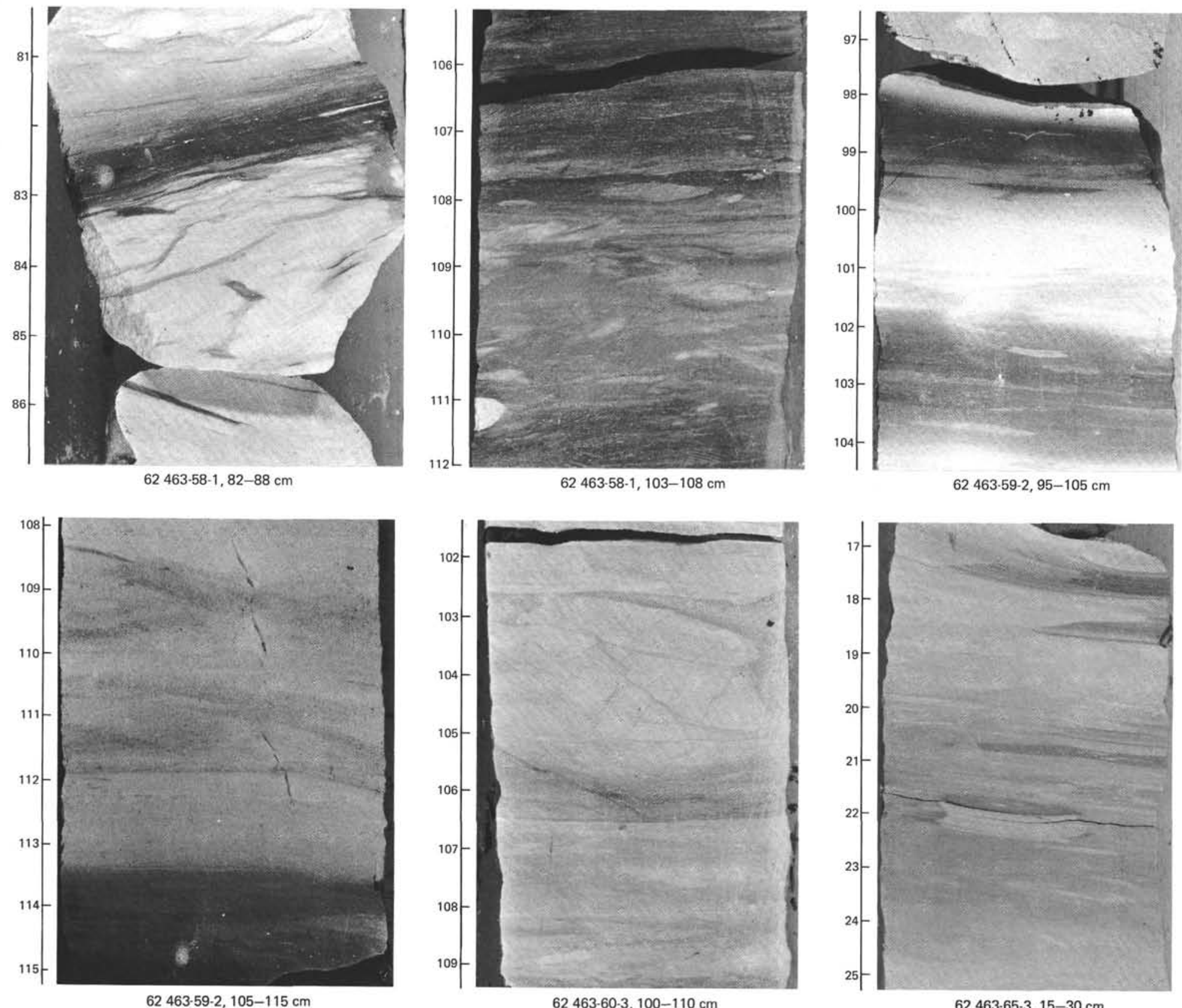

Figure 24. Details of sedimentary structures observed in the Aptian-Albian multicolored-limestone unit of Site 463. 


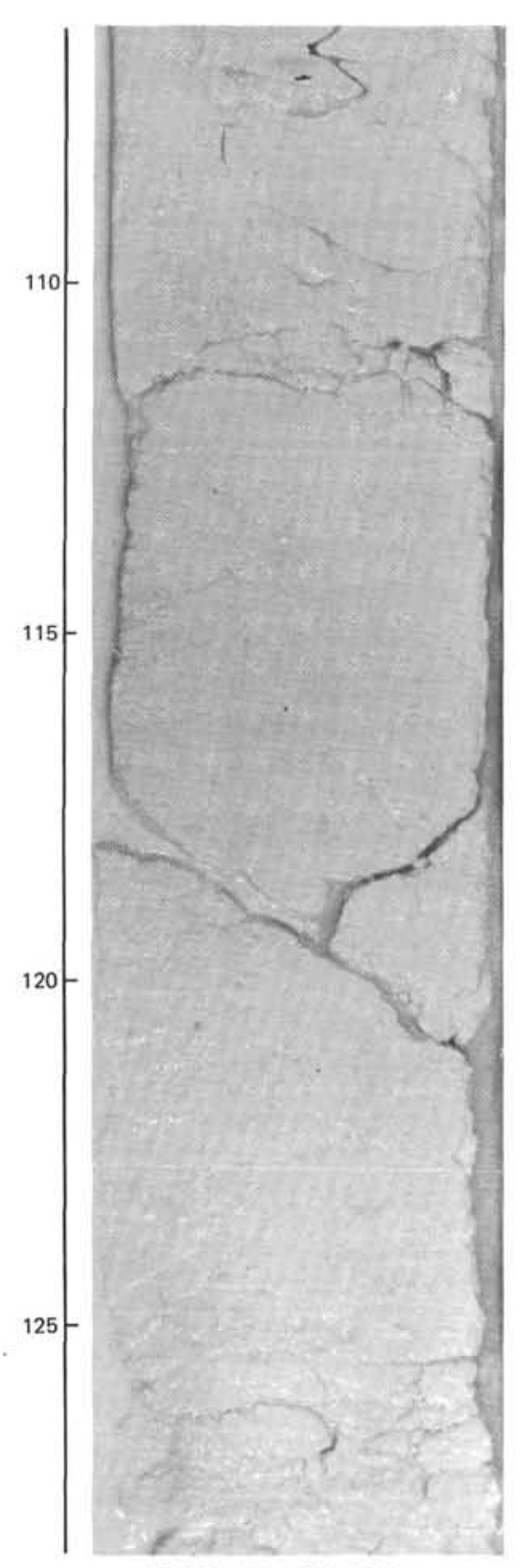

62 463-15-5, 110-125 cm

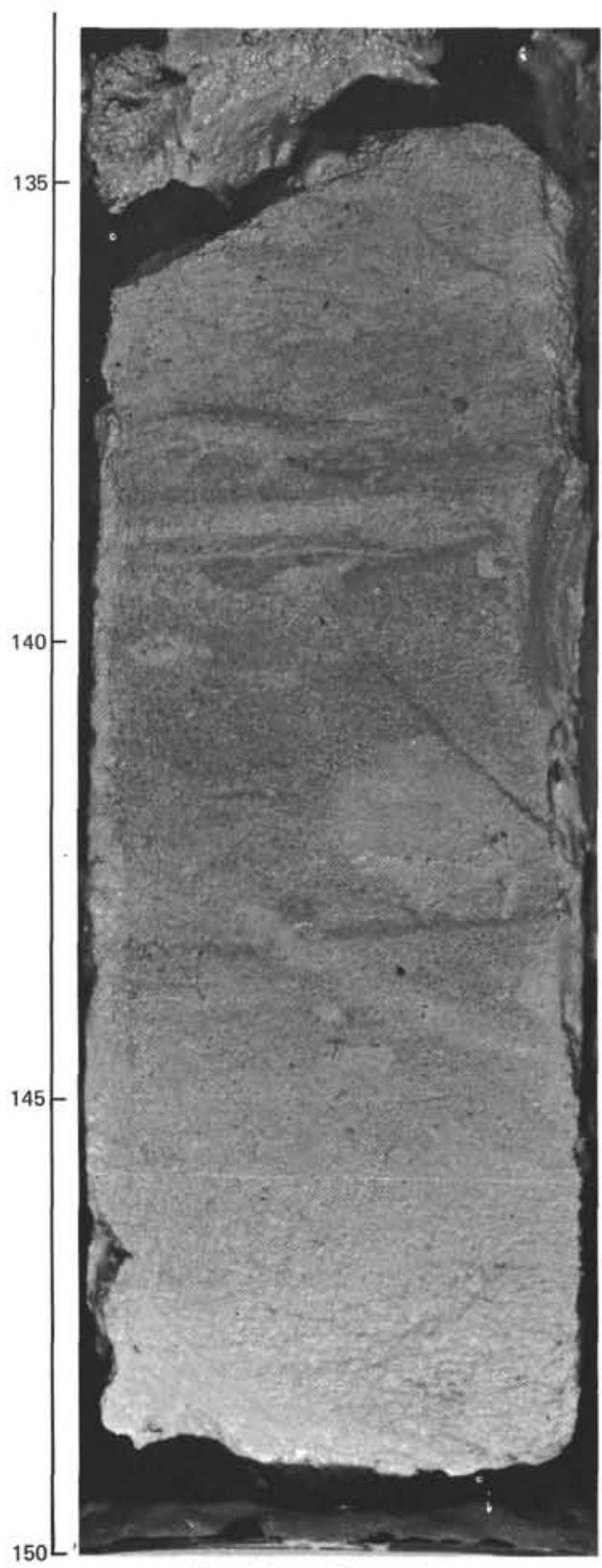

62 463-27-1, 135-150 cm

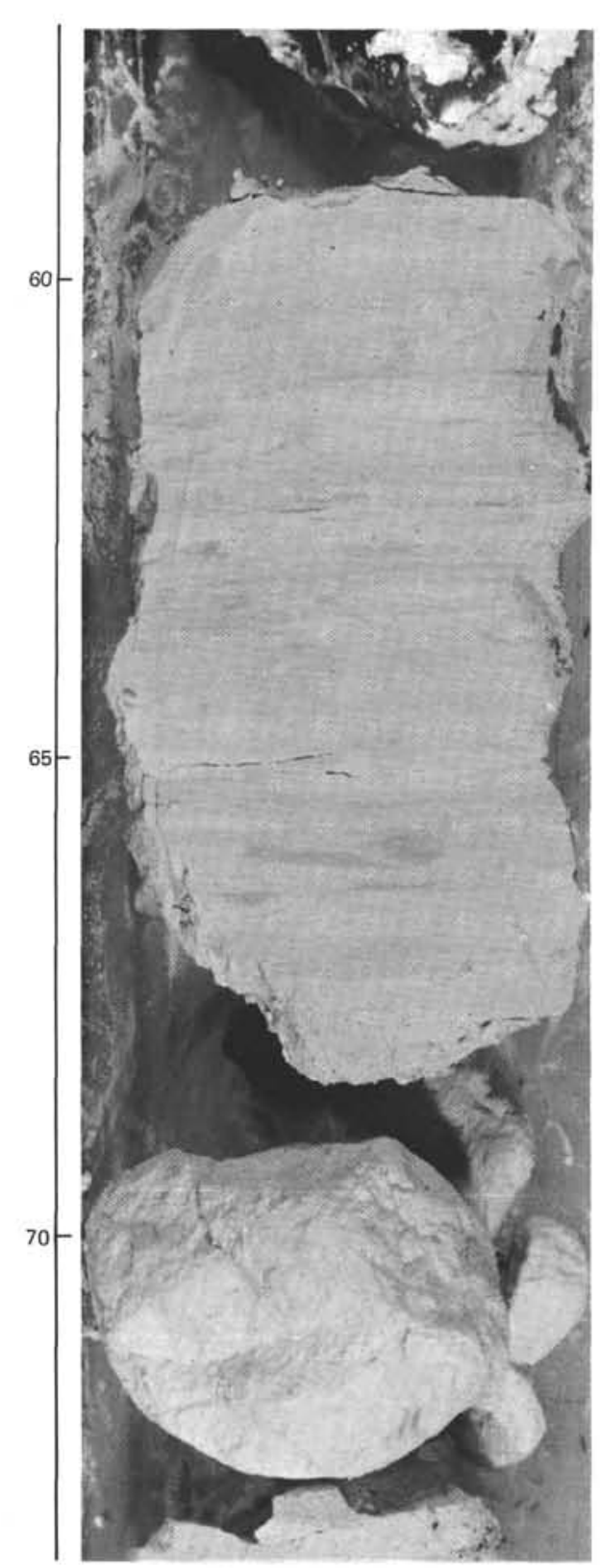

62 463-38-1, 60-70 cm

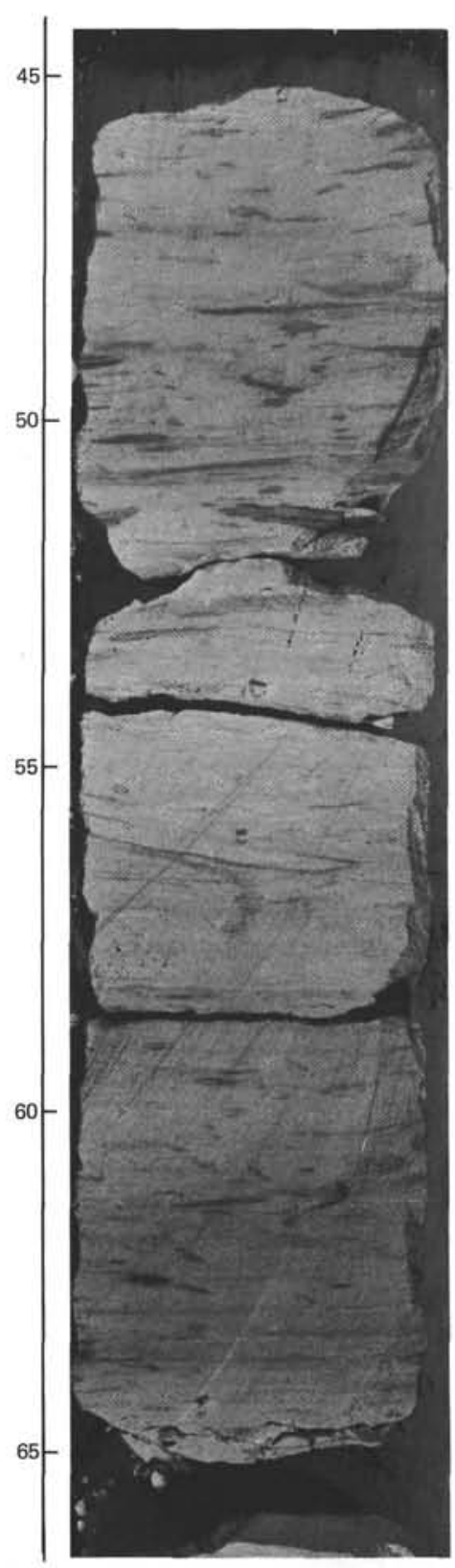

62 463-50-1, 45-65 cm 


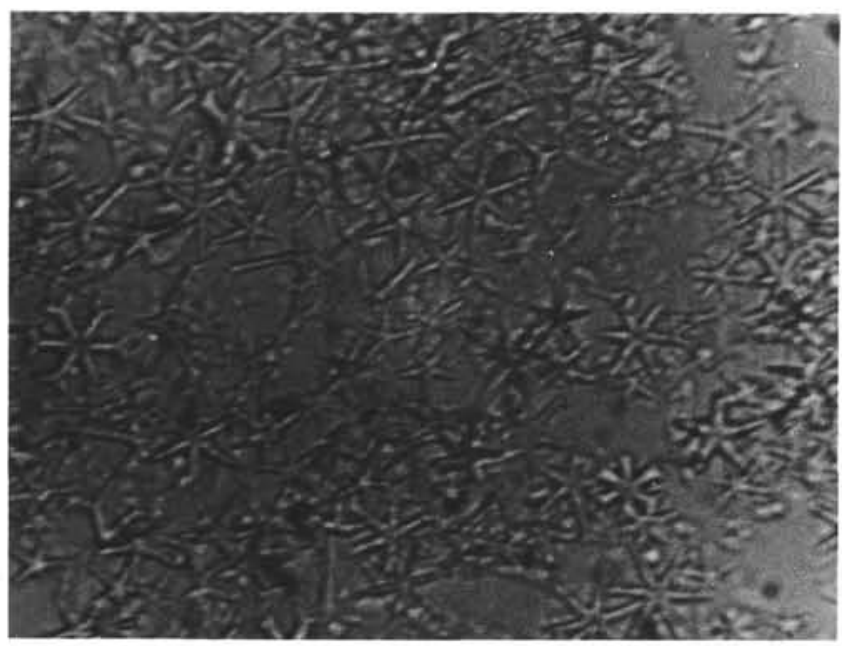

Figure 26. Pliocene discoaster ooze (Core 463-2) from Site 463.

$>80 \%$; see geochemistry section in Site 463 report, this volume), and in percent $\mathrm{Si}\left(\sim 2-40 \% \mathrm{Si} ; 4-85 \% \mathrm{SiO}_{2}\right.$; see Dean, this volume). Variable silicification can also be seen in thin sections in the variation of replacement, recrystallatization, and infilling of radiolarians and foraminifers (Figs. 31-37). Silicification actually begins in chalk of Lithologic Unit IB with partial to complete recrystallization and filling of radiolarians and foraminifers, but without destruction of the original chamber walls of the foraminifers (Figs. 31 and 32).

Compaction has compressed some chambers of radiolarians and foraminifers into elliptical, silica-filled clasts that may give an almost laminated appearance to the rock (Fig. 33). In some samples, this fabric is enhanced by subparallel to parallel orientation of echinoderm spines (Figs. 33 and 34). Some compaction is also evident in clasts in clastic limestone pressed into underlying pelagic carbonate (Fig. 35).

Additional features of silicification are shown in Figures 36 and 37. The clastic limestone beds in Lithologic Unit IV are of particular interest because they contain clasts composed predominantly of shallow-water carbonate debris, although there is no indication of how far down-slope these clasts may have been transported. The most common clasts are individual oolites, as well as rounded fragments of oolitic and pelletal limestone, and fragments of large mollusks and echinoderms (Figs. 38-44). The oolites in the fragments of oolitic limestone are much smaller than the individual oolites. In fact, some of the oolites are greater than $2 \mathrm{~mm}$ in diameter and should therefore be called pisolites, and some of the pisolites and larger oolites appear to be algal and are probably oncolites. Other tentatively identified shallowwater carbonate clasts are fragments of what appear to be coralline red algae and coral (Figures 45 and 46). Many of the clasts have margins that are riddled with algal borings (Figures 40 and 47).

Pressure solution, probably due to compaction, is indicated by wispy, stylolitic laminations (Figs. 43 and 44) and by interpretation of clasts (Fig. 44).

\section{SUMMARY OF THE GEOLOGIC HISTORY OF THE MID-PACIFIC MOUNTAINS AND THEIR DEPOSITIONAL ENVIRONMENT}

The earliest history of the western Mid-Pacific Mountains, and especially the magmatic events leading to the construction of the two platforms of the Mid-Pacific Mountains, remains unknown because of our failure to reach basement; however, we know that the volcanic events must have happened well before Barremian time, and well before the construction of the guyots of the eastern Mid-Pacific Mountains. Volcanic ashes intercalated in the sediments of Site 463 and other central Pacific and deep-sea drilling sites (Schlanger et al., 1981) suggest that these volcanic events happened in pulses (Vallier and Rea, 1980) during Aptian and Campanian time (Fig. 12). The mid-plate volcanism which led to the construction of the guyots generated trachytes and alkali basalts which have been sampled on the eastern Mid-Pacific Mountains and on Hess Rise (Seifert et al., this volume). The only evidence for these rocks observed as Site 463 consists of volcanic ashes where abundance decrease drastically after deposition of the Aptian tuffaceous and carbonaceous limestone, and of small rounded volcanic pebbles included in the clastic limestones of Barremian and early Aptian age.

The sedimentary column of Site 463 on the Mid-Pacific Mountains documents the depositional history of a large mid-Pacific aseismic rise which was built during a phase of intensive Early Cretaceous volcanic activity south of the Equator, and which once represented large tropical volcanic islands (Figs. 13, 14, and 15). These islands subsided rapidly after their formation, but parts of the aseismic rise formed shoal areas for long times as this part of the Pacific Plate moved northward across the equator into the central subtropical and temperate North Pacific Ocean. The accumulation rates of inorganic sediment components (Rea and Janecek, this volume) were high during the early phase of the depositional history of the Mid-Pacific Mountains, when weathered erosional products of wind-blown material from the oceanic islands, and carbonate debris from the neritic regions surrounding these islands, were shed over the island slope, especially during phases of low levels (Vail et al., 1977; Thiede et al., this volume). The composition of the displaced shallow-water carbonate clasts allows us to describe the neritic paleoenvironments which once existed on shoal areas in the Mid-Pacific Mountains. They constituted part of a belt of subtropical to tropical Urgonian shallow-water facies which can be traced around the globe (Fig. 48).

Reworked and displaced shallow-water benthic fossils incorporated in deep-sea sediments from the central Pacific Ocean bear evidence of the former presence and nature of the many depositional environments of shoals which once reached into the photic zone and which were once the locales of extensive carbonate deposition (Hamilton, 1956; Matthews et al., 1974). Such shallow water carbonates have been documented by deep-sea drill sites and by extensive dredging. Most of the central 


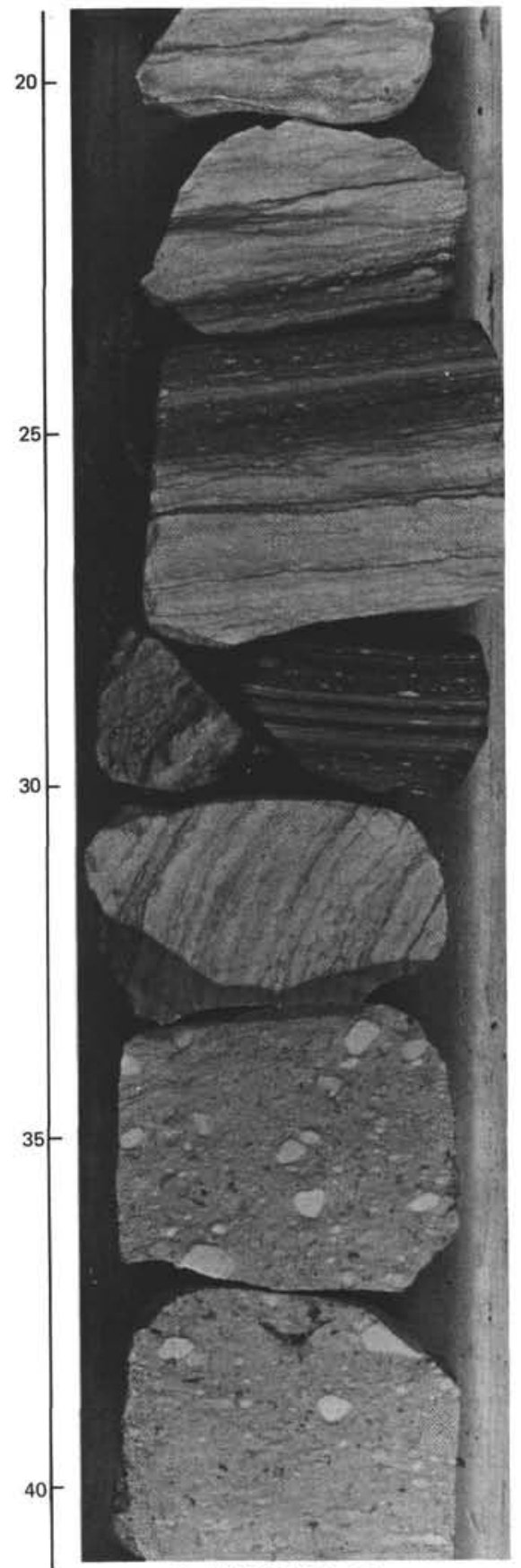

$62463-85-2,20-40 \mathrm{~cm}$

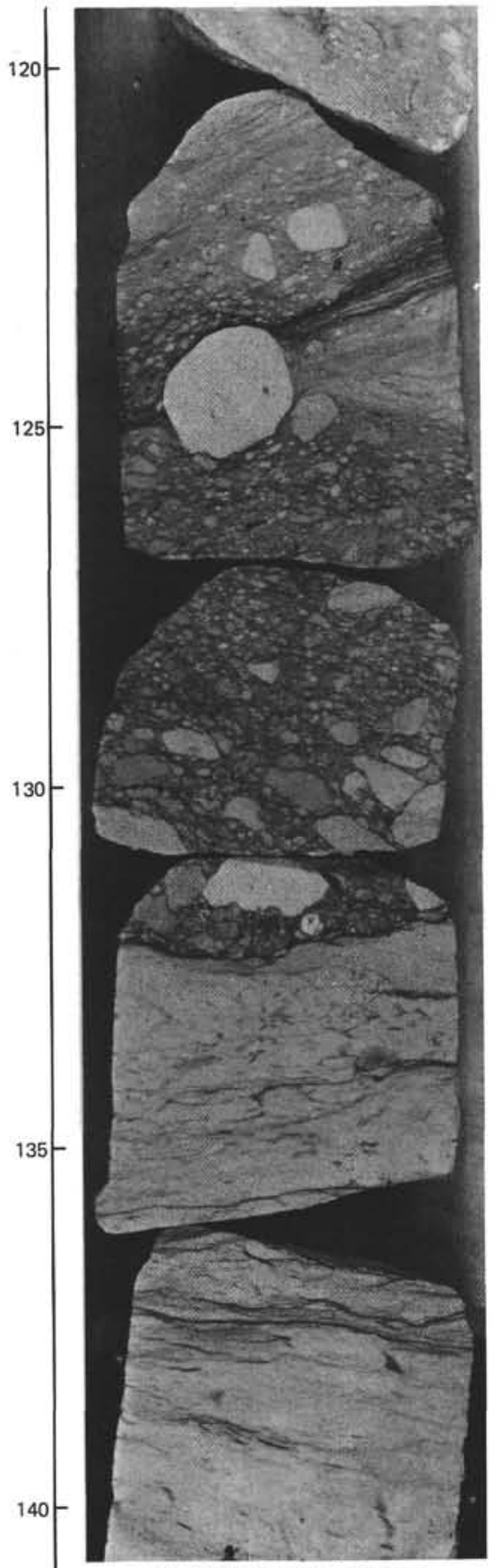

62 463-85-2, $120-140 \mathrm{~cm}$

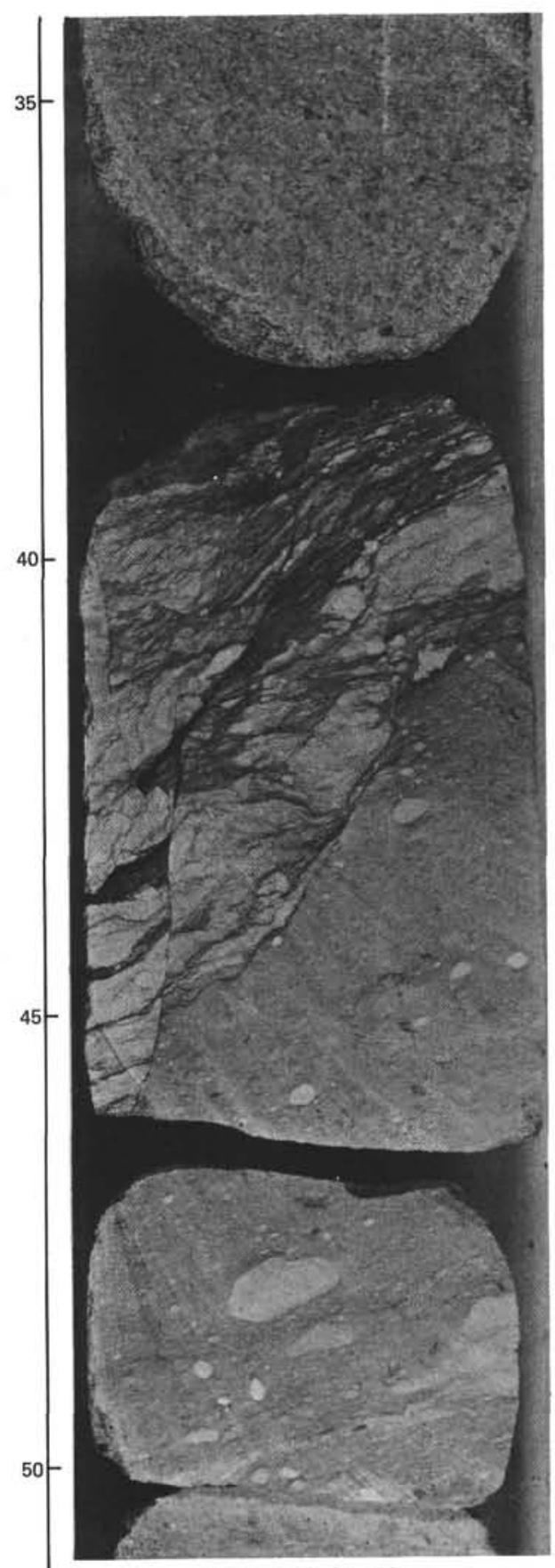

62 463-86-1, 35-50 cm

Figure 27. Examples of cores from Site 463 with clastic, shallow-water-derived limestone conglomerates interbedded with Barremian and lower Aptian pelagic limestones.

Pacific guyots have been found to be capped by Cretaceous carbonates (Heezen et al., 1973) and volcanic rocks of highly variable composition (Natland, 1976; Jackson and Schlanger, 1976). It has been assumed that most of the late Mesozoic shallow-water carbonate environments ceased to exist as a result of submergence (Matthews et al., 1974) caused by rapid eustatic sea-level rises.

The youngest reworked shallow-water fossils observed in the Mid-Pacific Mountains are of Maastrichtian, possibly Danian age (Hamilton, 1956); the older fossils are of Barremian age (both at Site 463). Therefore, it seems clear that neritic environments around the peaks of the guyots of the Mid-Pacific Mountains ceased to exist at that time. This is interesting to note because sea level, which had started to drop after its mid-Cretaceous high (Vail et al., 1977), now reached the tops of the subsiding guyots. Only during short but drastic drops of sea level below its general level did erosionpossibly at wave base-reach the older sediments.

The neritic facies in the central Pacific Ocean deepsea drill sites (Fig. 28) document the repeated injection 


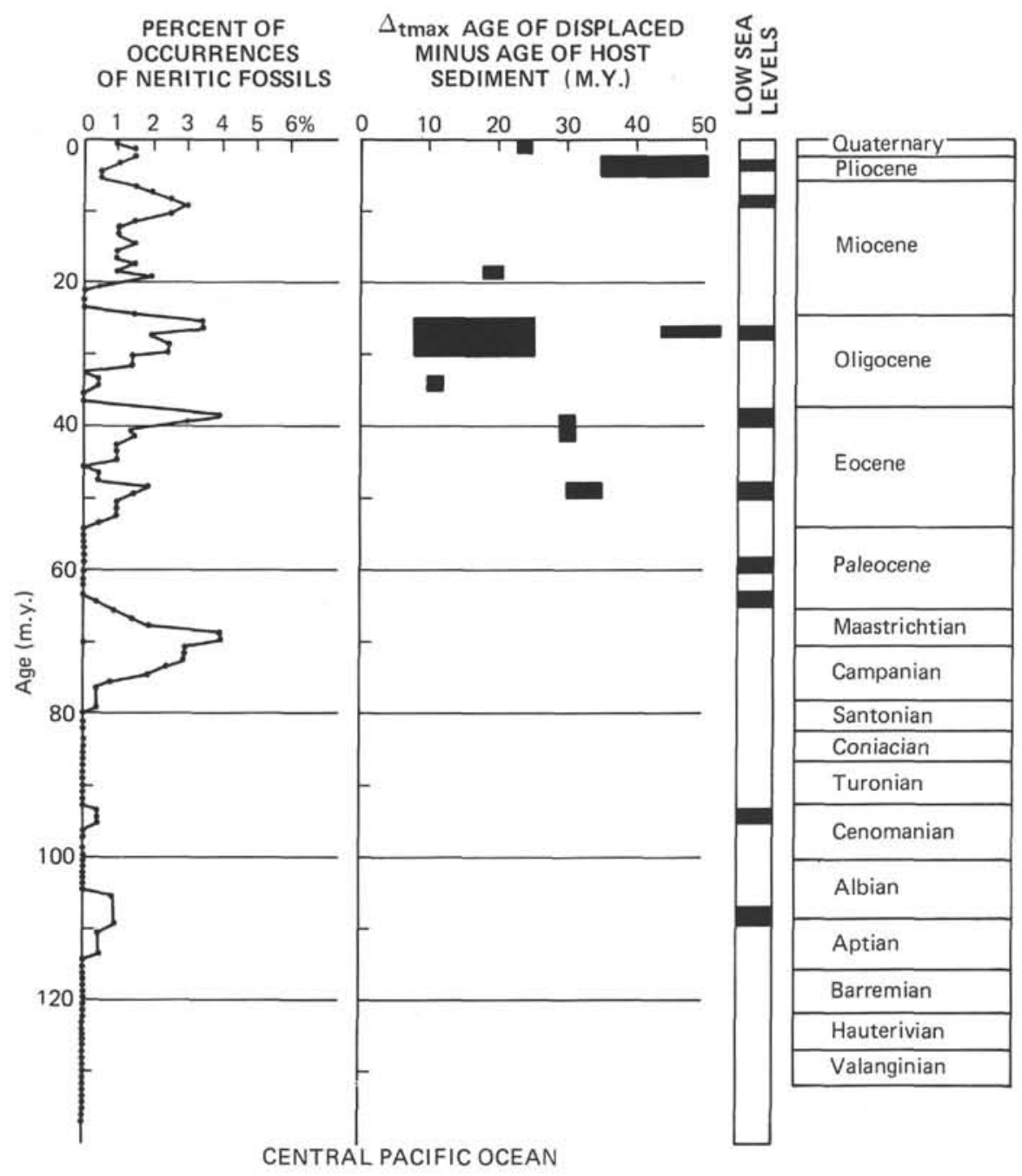

Figure 28. Occurrences and ages of displaced, shallow-water-derived fossils in drill sites from the subtropical and tropical central western Pacific Ocean (from Thiede et al., this volume). Occurrence is expressed in percent of all observations of reworked shallow-water-derived material. $\Delta_{t}$ is the maximum time difference between the age of the reworked displaced sediment components and the time of their redeposition. The ages of low eustatic sea-level stands have been marked according to Vail et al. (1977).

of shallow-water debris into the adjacent deep-sea basins throughout the late Mesozoic and the Cenozoic as a sequence of short-lived episodic events separated by intervals when very little or no shallow-water benthic fossil material reached the floor of the deep-sea basins. The events-except the Campanian-Maastrichtian one-coincide with low eustatic sea-level stands (Vail et al., 1977), and therefore probably represent erosion that occurred close to the lowered sea-level stand during those intervals. The Campanian-Maastrichtian event is a special case because it is the most important one of the late Mesozoic paleoenvironment; it apparently did not coincide with very low eustatic sea levels (Vail et al., 1977; McCoy and Zimmermann, 1977), but it preceded an interval of important hiatuses in the central Pacific Ocean across the Cretaceous/Tertiary boundary; however, this interval was coeval with a major phase of widespread volcanic activity (Jackson and Schlanger, 1976; Schlanger et al., 1981) in the central Pacific Ocean which led to the deposition of volcanic ashes in the Mariana Basin, along the Line Islands, and on Horizon Guyot.

Oxygen-deficient depositional environments developed in the central Pacific Ocean over a time span of 30 to $35 \mathrm{~m} . y$. during the Cretaceous; they were not isochronous events which affected the entire basin. Sites containing organic-carbon-rich strata of mid-Cretaceous age are restricted to certain areas which were spread over $45^{\circ}$ of paleolatitude (Fig. 14).

Two types of oxygen-deficient depositional environments have been observed (Thiede et al., in press; Dean et al., this volume); both developed at intermediate water depths along the flanks of large aseismic rises in the central tropical and subtropical late Mesozoic $\mathrm{Pa}$ cific Ocean which were emergent at times. Debris of land plants and terrigenous organic matter (Melieres et al., this volume), the probable subaerial volcanism on some of the aseismic rises, the altered clay-mineral assemblages, and fossil assemblages displaced from ne- 


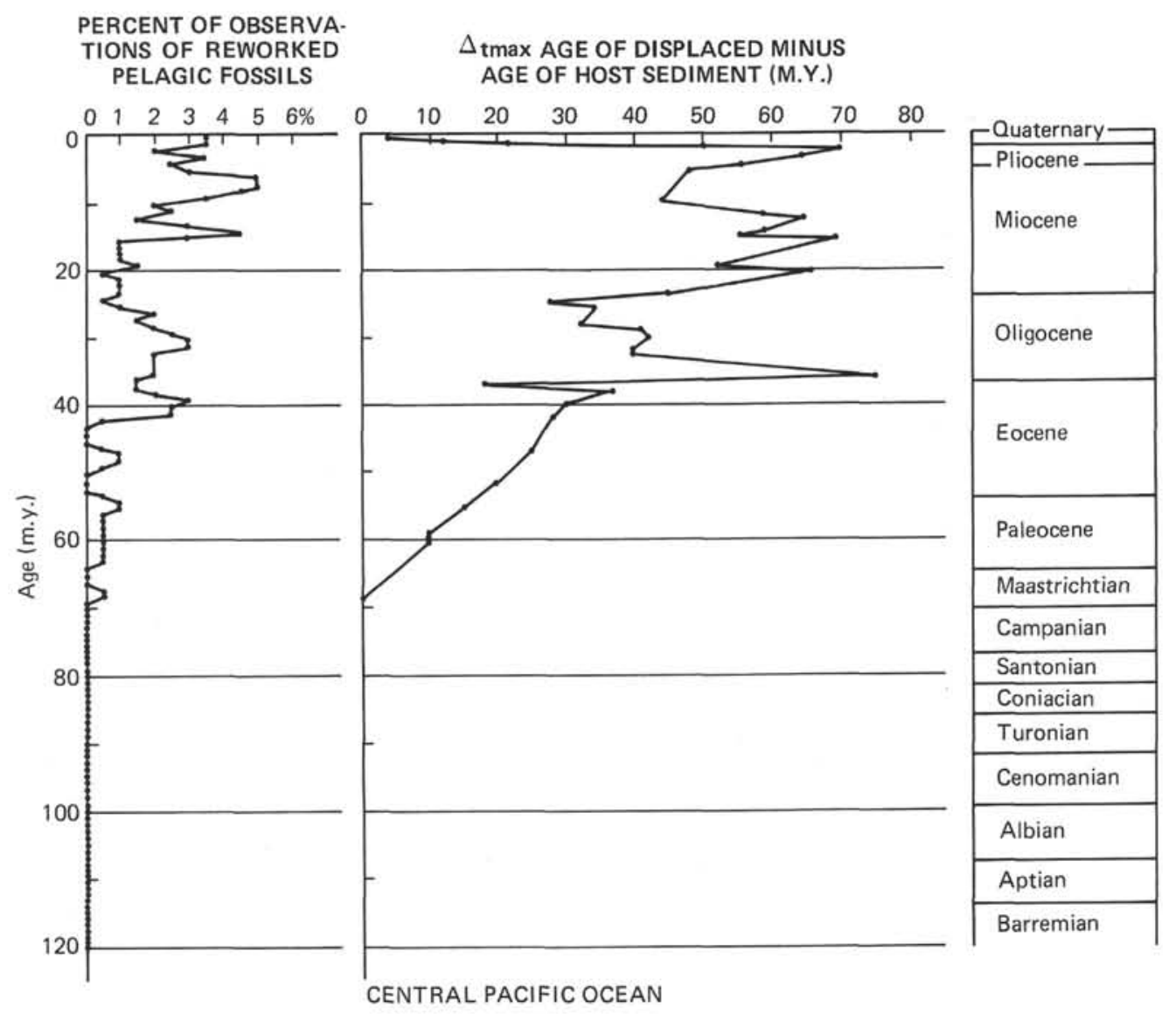

Figure 29. Observations of occurrences of non-contemporaneous reworked pelagic fossils (calcareous nannofossils, planktonic foraminifers, radiolarians) in drill sites from the tropical and subtropical central western Pacific Ocean (from Thiede et al., this volume). Occurrence is expressed in per cent of all observations. $\Delta_{t}$ marks the maximum time difference between the age of the reworked material and the time of final redeposition.

ritic environments around the islands are evidence for this scenario. One of the oxygen-deficient environments led to very short-lived events of complete oxygen depletion, as at Site 463 , probably in connection with volcanic activity, and is documented in the sediments by the coincidence of volcanogenic sediments and thin horizons of laminated, organic-carbon-rich rocks. These environments seem to have been restricted to relatively small areas on the rises, because they have not been sampled in adjacent drill sites; however, the poor recovery of many Pacific Mesozoic sections, mainly because of abundant chert, limits the validity of this observation. Such environments may have developed repeatedly along the same rise in response to pulses of volcanic activity. All occurrences except those at Sites 465 and 466 on southern Hess Rise belong to this type of depositional environment; its main characteristics are its small regional exent, its short duration, its thin deposits, and its coincidence with volcanic activity. The other type of oxygen-deficient depositional environment (not observed in the Mid-Pacific Mountains) lasted over several million years and led to the deposition of thick sequences of organic-carbon-rich pelagic strata which accumulated when the site crossed under the equatorial divergence as the Pacific Plate moved northward during the Meso- zoic. This depositional environment is documented at Sites 465 and 466 on southern Hess Rise.

Distributions of non-coeval reworked pelagic sediment components allow us to make inferences about eroding bottom-water current regimes, which seem to have undergone important changes since Mesozoic time (Fig. 29). Maastrichtian reworking of the immediately underlying Campanian sediments obviously represents the formation of currents in the intermediate water masses of the Pacific Ocean which were able not only to transport and displace coeval sediments, but also to erode into the underlying older sediments.

Even though the available drill site data have to be considered preliminary (Thiede et al., this volume), the large quantitative difference in the occurrences of planktonic fossils during pre-Maastrichtian and Maastrichtian-Pleistocene time seems to point to a fundamental change of the depositional paleoenvironment of the deep central Pacific Ocean, and probably of the world ocean in general. If the physical properties of deep-sea sediments (Schlanger and Douglas, 1974) deposited during pre-Campanian time in the central $\mathrm{Pa}$ cific Ocean were not drastically different from those laid down during the past 75 m.y., then their susceptibility to erosion should have been approximately the 


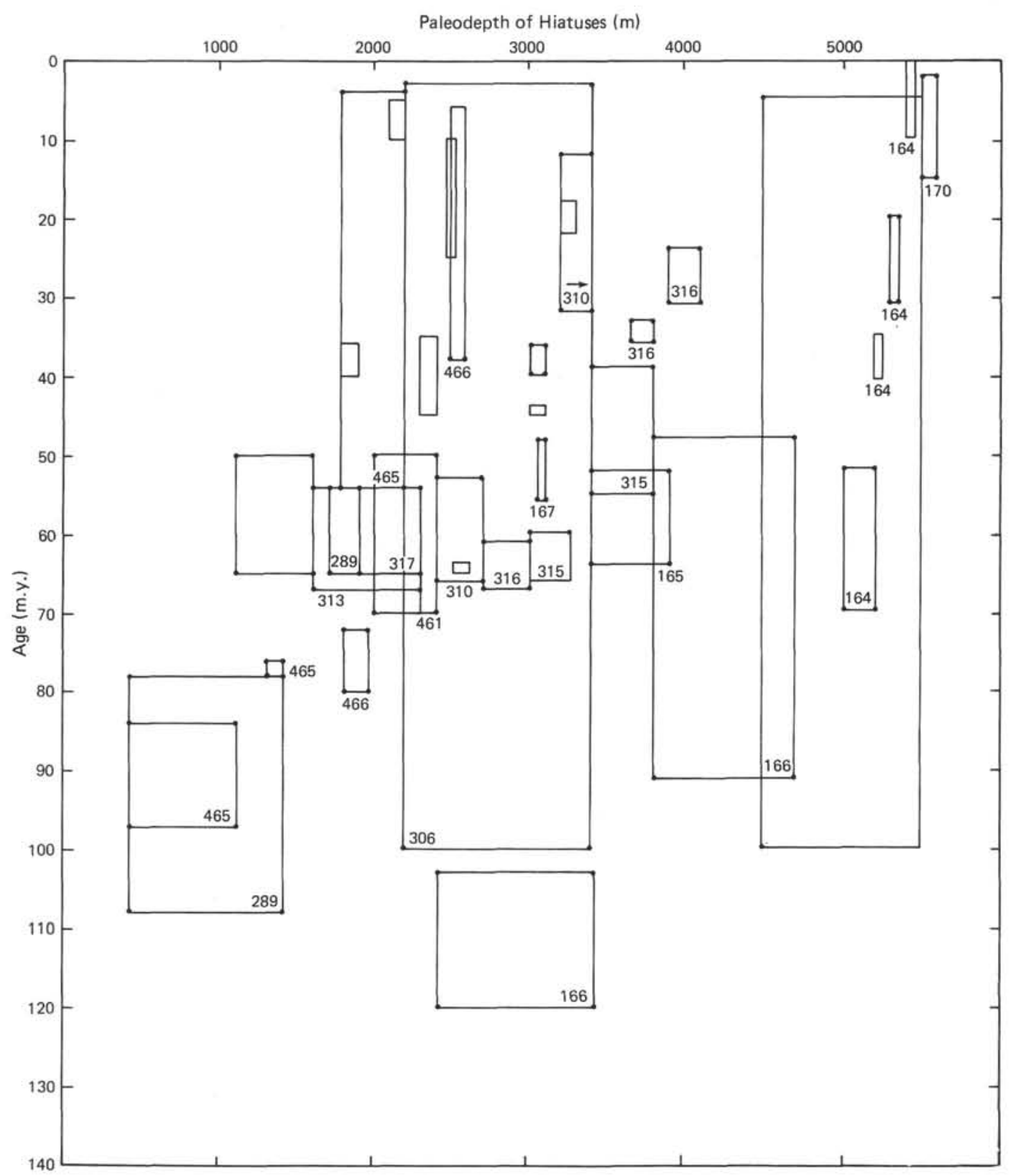

Figure 30. Paleodepth and age distribution of major hiatuses in the central Pacific Ocean.

same. If diagenetic changes have effected the susceptibility to erosion of the pre-Campanian central Pacific deep-sea sediments, then such changes must have occurred soon after deposition of the sediments. The coincidence of the lack of non-coeval reworked pelagic fossil material and of the repeated development of oxygendeficient depositional environments between 80 and 120 m.y. ago (which must have had a very quiet and sluggish bottom-water circulation, as documented by their laminated sediments; Dean et al., this volume) seems to support the interpretation that a wide area of the pre-Campanian central Pacific Ocean has not experienced bottom-water currents strong enough to erode older strata. Relatively rapidly flowing currents seem to have been confined to the upper few hundred meters of the water column, especially close to the equatorial divergence (Dean et al., this volume).
The age distribution of the reworked and displaced non-coeval pelagic fossils and the difference between the age of reworked components and time of redeposition in the central Pacific Ocean is particularly interesting (Fig. 29). In the central Pacific Ocean, this age difference approached zero during Maastrichtian time, but increased fairly regularly throughout the Cenozoic to the early Pleistocene. The regular increase must mean that the entire sediment column which had been laid down since initiation of this erosional regime in early Maastrichtian time was subject to continuous erosion and redeposition. Deviations from the regular increase of the maximum time difference between the age of the reworked material and the time of redeposition have been observed for the early and late Oligocene, as well as the late Miocene and Quaternary. Minima of this curve (Fig. 29) coincide with episodes of high pelagic ac- 


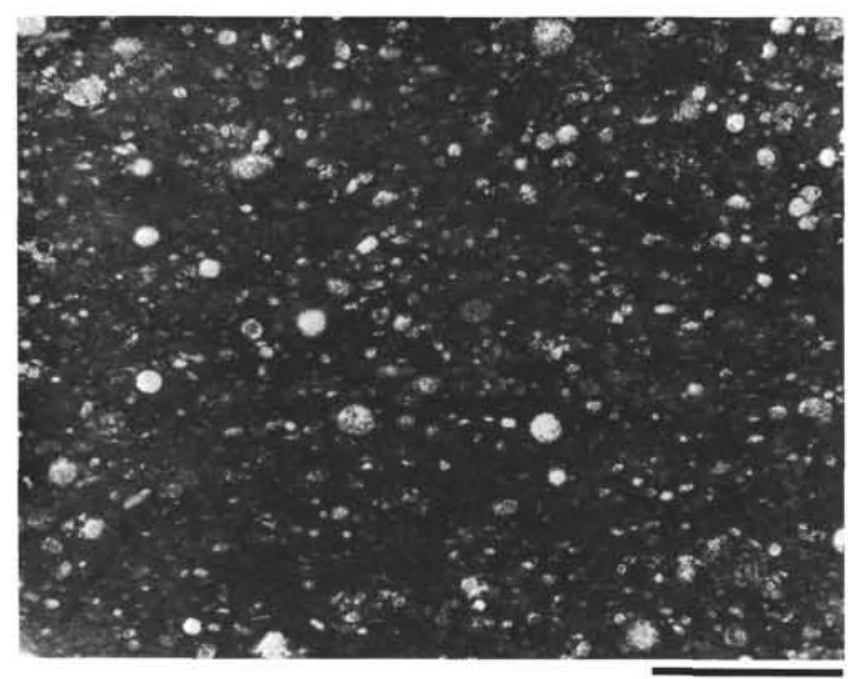

Figure 31. Sample 463-36-1, $0 \mathrm{~cm}$. Silicified nannofossil chalk, Lithologic Unit IB. Radiolarians and foraminifers partly to completely replaced and filled with silica. The walls of many foraminifera are still visible. Plane light; bar $=1 \mathrm{~mm}$.

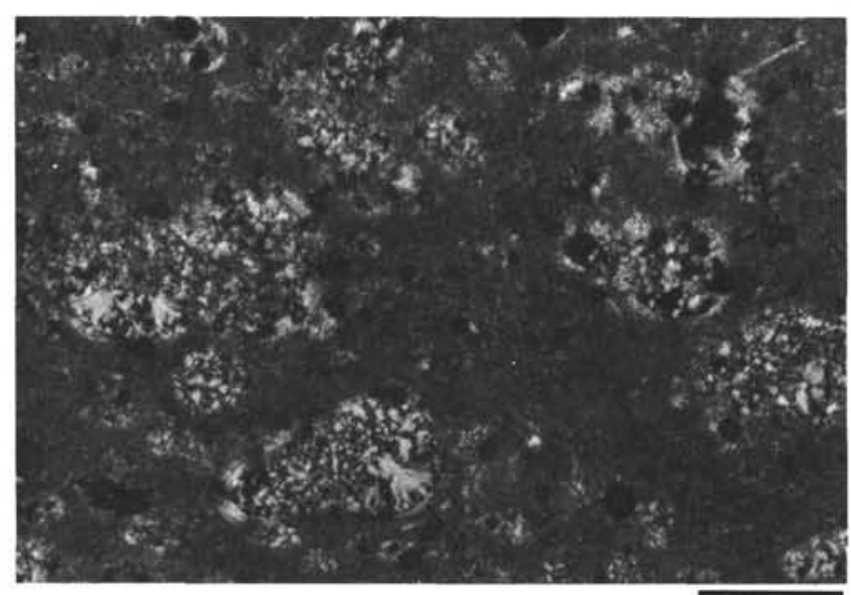

Figure 32. Sample 463-36-1, $0 \mathrm{~cm}$. Enlargement of Figure 31. Silicified foraminifers in a silicified micritic carbonate matrix. Note micritized walls (m) of most of the foraminifers. Cross-polarized light; bar $=0.2 \mathrm{~mm}$.

cumulation rates (van Andel et al., 1975; Worsley and Davies, 1979), and the maximum coincide with the development of important hiatuses in the western central Pacific Ocean (Moore et al., 1978). The simplicity of the argument that the reworked and displaced non-coeval fossils in deep-sea sediments imply mechanical transport suggests that mechanical erosion caused most of these hiatuses, rather than nondeposition or dissolution.

Accumulation rates of pelagic sediments were high during the Early and middle Cretaceous histories of the Mid-Pacific Mountains, because it was situated far above the CCD, and because productive surface water existed around and above it for a long time. The MidPacific Mountains were generated south the late Mesozoic Equator, but they traveled northward with the $\mathrm{Pa}$ cific Plate. The traverse of the shallow regions across

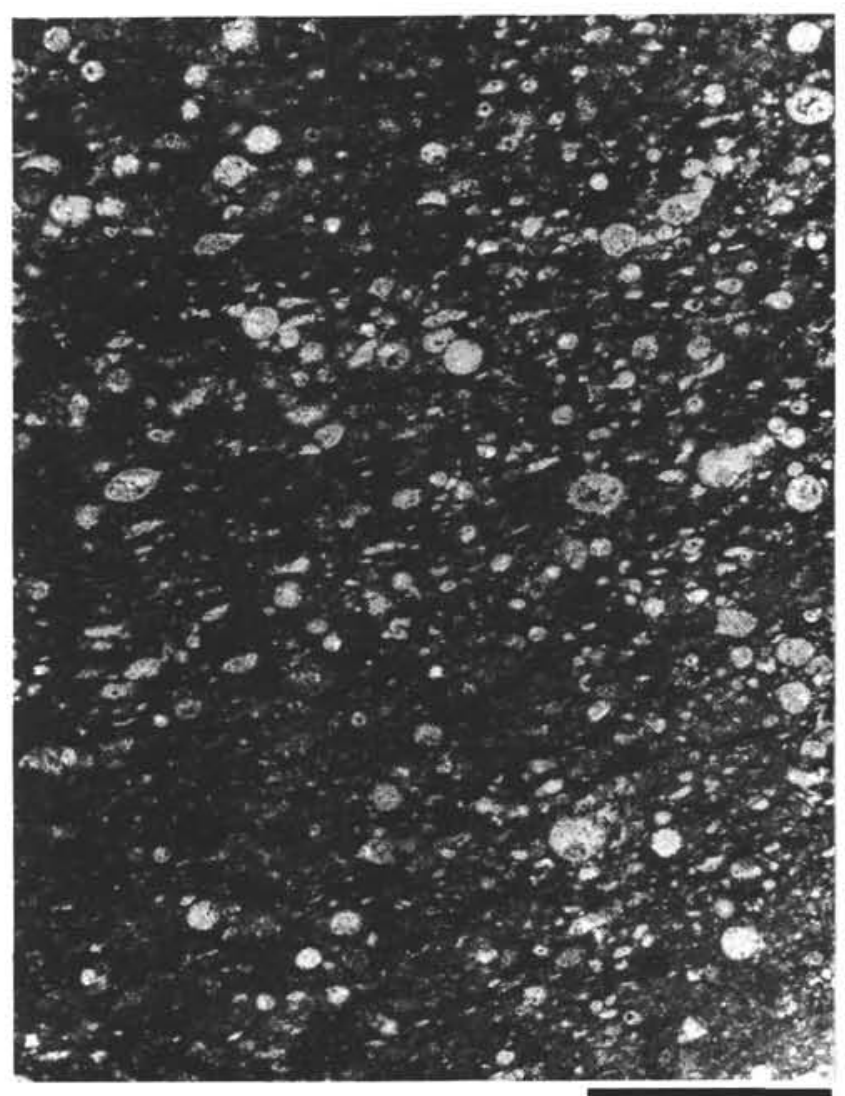

Figure 33. Sample 463-56-1, $98 \mathrm{~cm}$. Partly silicified, greenish-gray limestone, Lithologic Unit II. Radiolarians and foraminifers partly to completely replaced and filled with silica. Similar sample at $463-56-1,22 \mathrm{~cm}$ contains $15 \% \mathrm{SiO}_{2}$. Most of the matrix is still micritic calcite. Elongate calcite fragment(s) are probably echinoderm spines, as evidenced by single-crystal extinction and bulbose ends on some of the fragments. Note the tendency for a parallel fabric as a result of parallel orientation of most of the spines and compactional flattening of some of the radiolarians and foraminifers. Plane light; $b a r=1 \mathrm{~mm}$.

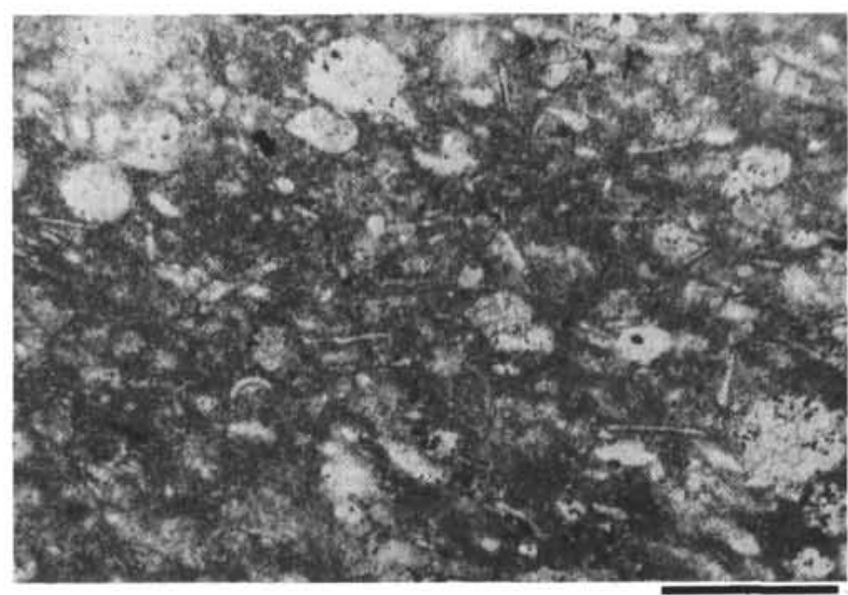

Figure 34. Sample 463-56-1, $98 \mathrm{~cm}$. Enlargement of Figure 33, showing parallel orientation of echinoderm(?) spines. Cross-polarized light; bar $=0.5 \mathrm{~mm}$. 


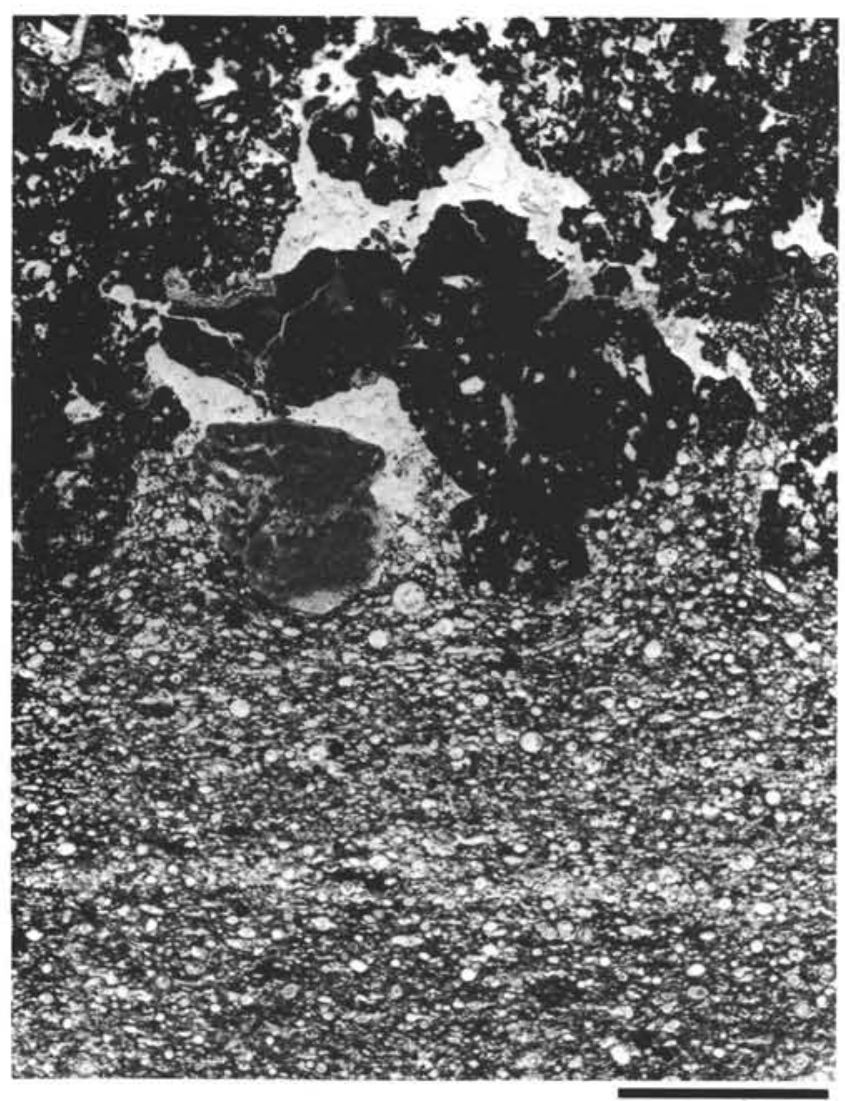

Figure 35. Sample 463-74-1, $74 \mathrm{~cm}$. Contact between greenish-gray pelagic limestone (bottom) and clastic limestone, Lithologic Unit IV. Note that clastic grains have been pushed into the underlying pelagic limestone. Plane light; $b a r=2 \mathrm{~mm}$.

the westward-flowing equatorial current regime generated a time-transgressive pelagic depositional environment characterized by highly variable accumulation rates, the development of hiatuses, and sediments with high concentrations of opaline fossils, which is typical of very productive surface water masses, and which in part resulted in the common occurrence of chert in the Upper Cretaceous sequences. Accumulation rates of the pelagic sediments laid down while crossing under the equatorial divergence are higher than before and after because the high flux of calcareous components depressed the CCD into deeper waters (Berger and Winterer, 1974) than north and south of the Equator. This depositional environment is expressed in the sedimentary record of Site 463 by higher-than-usual accumulation rates of calcareous pelagic deposits. The Mid-Pacific Mountains had reached the sterile subtropical to temperate central North Pacific in early Tertiary time, when they had subsided into intermediate and deep waters. The calcareous pelagic components of the condensed Cenozoic sediments are therefore fragmented or poorly preserved, and the continuity of the Cenozoic sedimentary sequences has been interrupted by important episodes of erosion. The accumulation rates of the Cenozoic sediments are therefore very low in comparison to the Mesozoic accumulation rates.

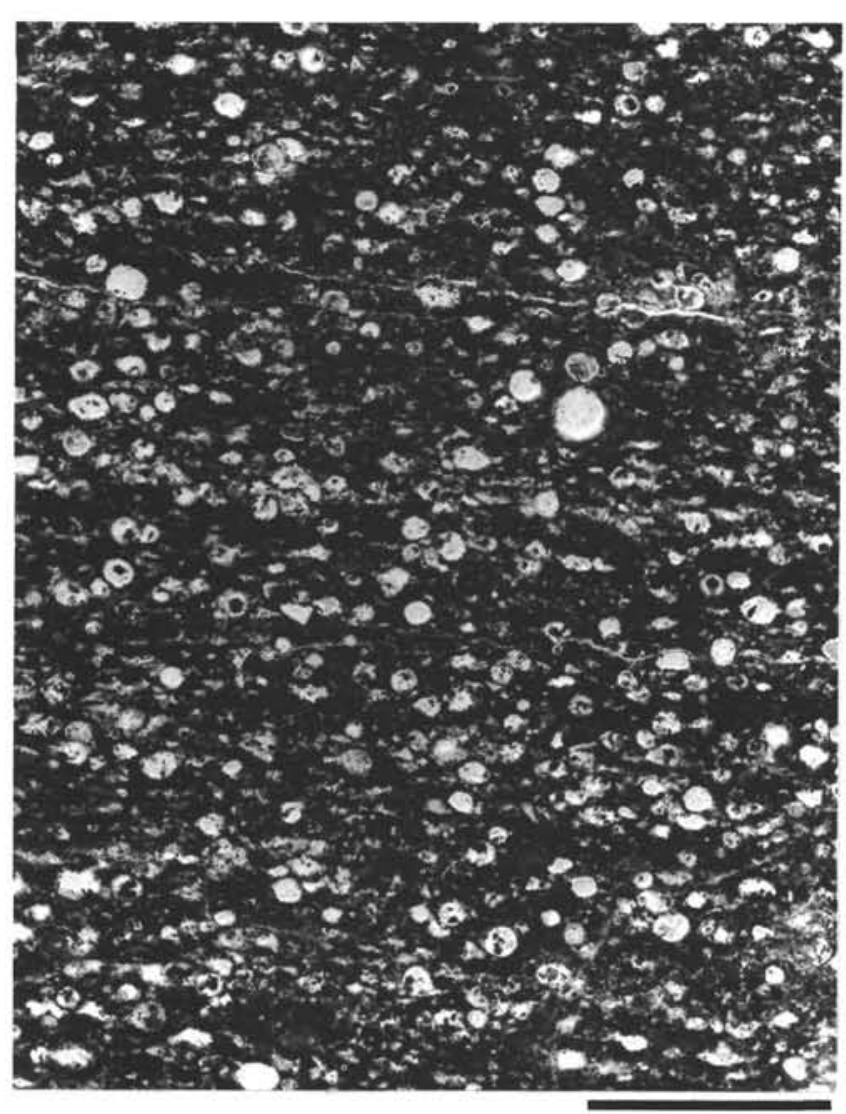

Figure 36. Sample 463-77-1, $62 \mathrm{~cm}$. Pelagic limestone typical of Lithologic Unit IV. Note abundant radiolarians recrystallized and filled with silica. Similar sample at $463-77-1,60 \mathrm{~cm}$ contains $7 \% \mathrm{SiO}_{2}$. Cross-polarized light; bar $=1 \mathrm{~mm}$.

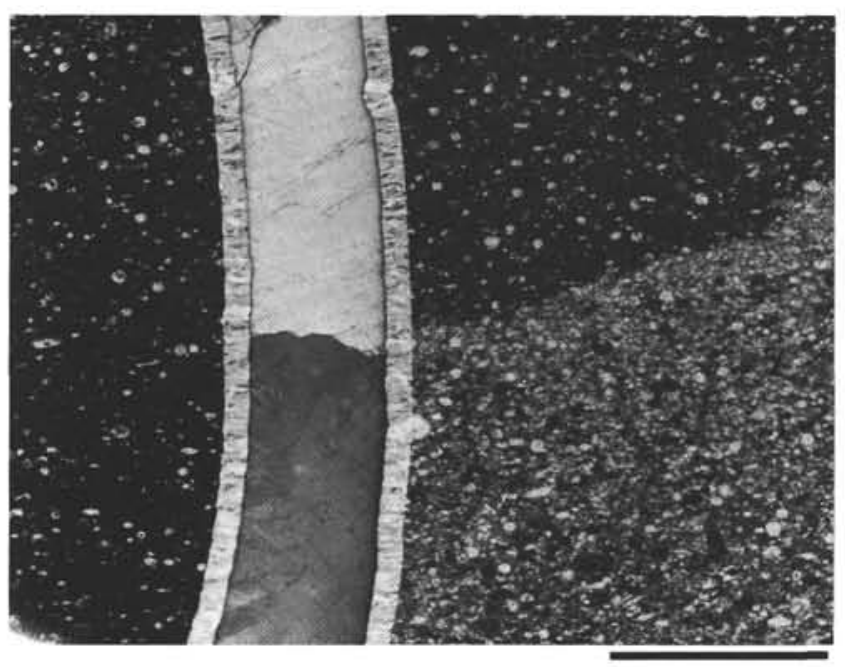

Figure 37. Sample $463-83-1,73 \mathrm{~cm}$. Silicified pelagic limestone of Lithologic Unit IV, with abundant recrystallized and filled radiolarians. Sample is cut by a calcite vein lined with chalcedony. This sample also shows varying degrees of silicification; the area at the lower right (lighter color) has been silicified more than the rest of the sample. Cross-polarized light; $b a r=2 \mathrm{~mm}$. 


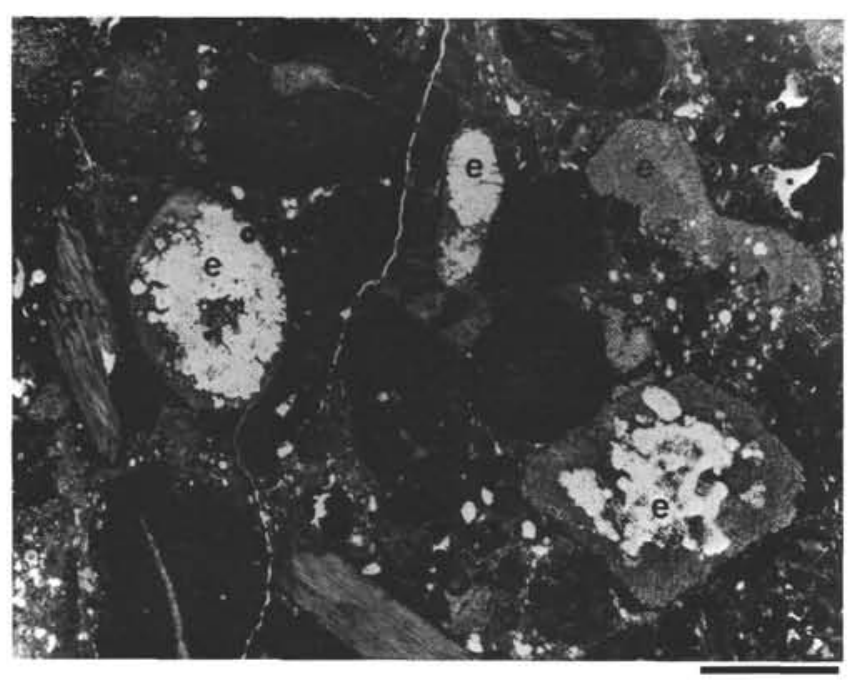

Figure 38. Sample 463-85-', $138 \mathrm{~cm}$. Clastic limestone interbedded with pelagic limestone, Lithologic Unit IV. Clasts are mostly shallow-water carbonate debris, including oolites and rounded fragments of oolitic limestone, and fragments of mollusks (m), echinoderms (e), and coral, partly replaced by silica. The margins of many of the clasts have been riddled by algal borings. Plane light; bar $=1 \mathrm{~mm}$.

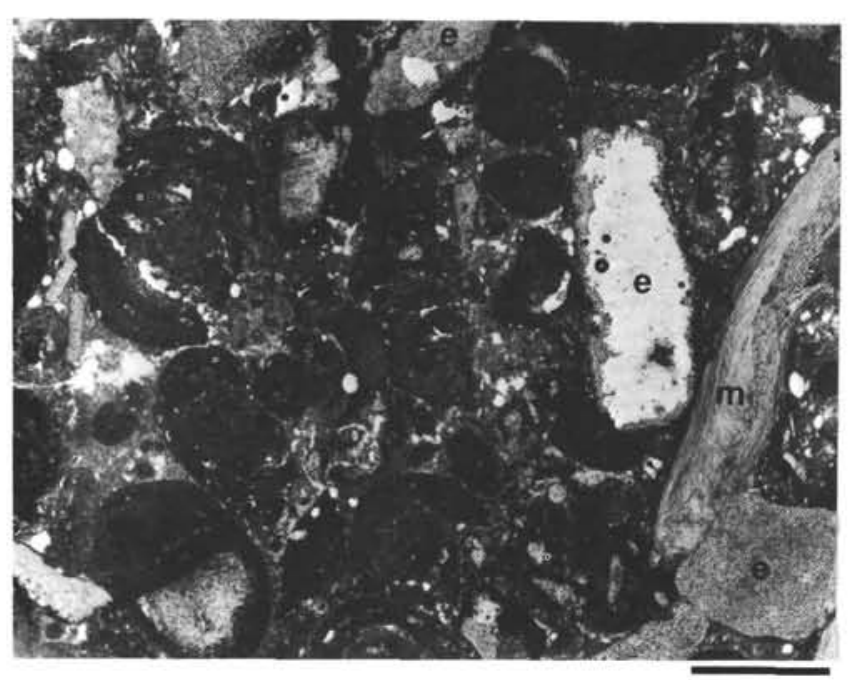

Figure 39. As in Figure 38.

\section{ACKNOWLEDGMENTS}

The results of this synthesis are based on the data generated by the entire shipboard party of Leg 62 and the previous Deep Sea Drilling Project legs to the central tropical and subtropical Pacific Ocean. The authors gratefully acknowledge the help and assistance of the Global Marine Inc. staff aboard D/V Glomar Challenger, and of colleagues (sea-going as well as land-based) of the Deep Sea Drilling Project.

\section{REFERENCES}

Andrews, J. E., Packham, G., et al., 1975. Init. Repts. DSDP, 30: Washington (U.S. Govt. Printing Office).

Arthur, M. A., and Schlanger, S. O., 1979. Cretaceous "oceanic anoxic events" as causal factors in development at reef-reservoired giant oil fields. Bull. Am. Assoc. Petrol. Geol., 63:870-885.

Bass, M. N., Moberly, R. M., Rhodes, J. M., et al., 1973. Volcanic rocks cored in the central Pacific Leg 17, Deep Sea Drilling Proj-

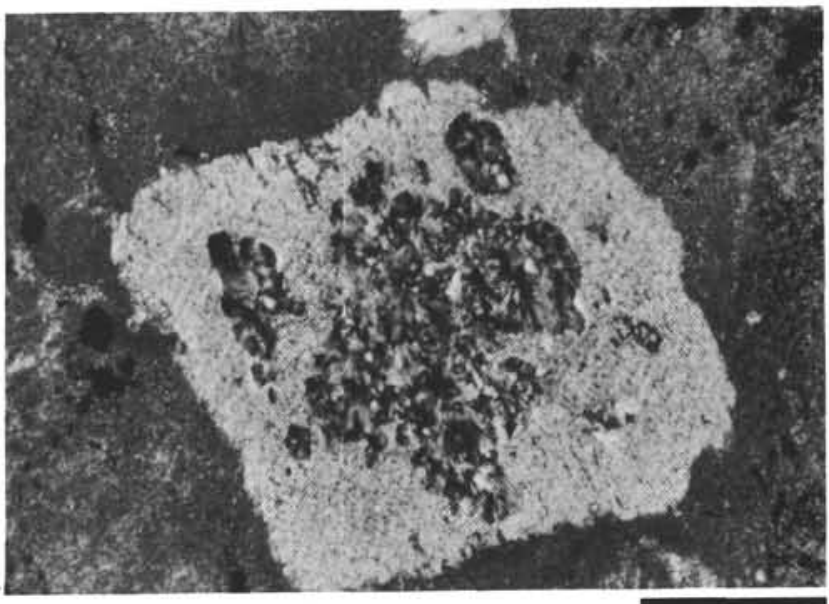

Figure 40. Sample $463-85-1,138 \mathrm{~cm}$. Echinoderm fragment partly replaced by silica, enlarged from Figure 38 . Fragment shows reticulate texture and single-crystal extinction characteristic of echinoderms. Note algal borings around margins. Cross-polarized light; bar $=0.5 \mathrm{~mm}$.

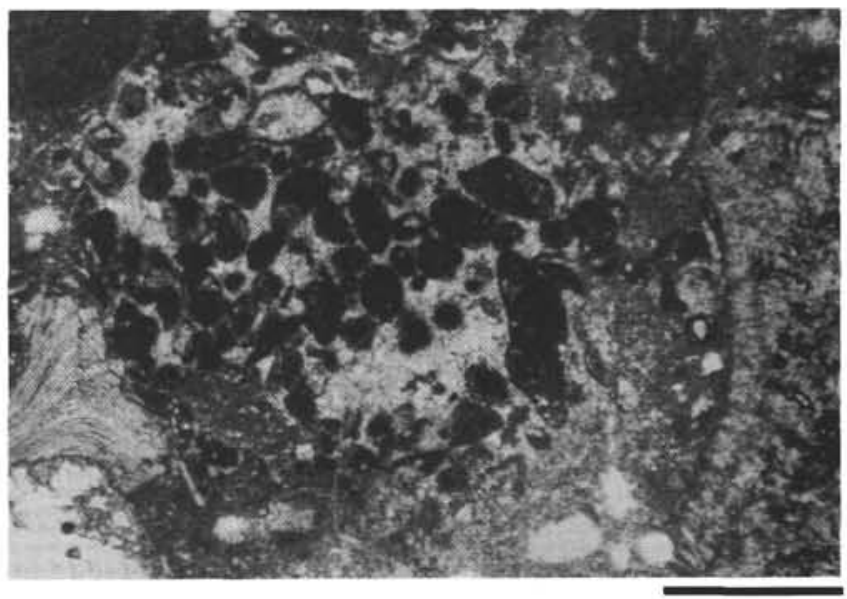

Figure 41. Sample 463-85-1, $138 \mathrm{~cm}$. Clasts of pelletal and oolitic limestone in clastic limestone. Cross-polarized light; bar $=0.5$ $\mathrm{mm}$.

ect. In Winterer, E. L., Ewing, J. I., et al., Init. Repts. DSDP, 17: Washington (U.S. Govt. Printing Office), 429-504.

Berger, W. H., and Winterer, E. L., 1974. Plate stratigraphy and the fluctuating carbonate line. Internat. Assoc. Sedimentol. Spec. Publ., 1:11-48.

Berggren, W. A., 1973. The Plıocene time scale: calibration of planktonic foraminiferal and calcareous nannoplankton zone. Nature, 243:391-397.

Berggren, W. A., and Van Couvering, J. A., 1974. The late Neogene: biostratigraphy, biochronology and paleoclimatology of the last 15 million years in marine and continental sediments. Palaeogeogr., Palaeoecol., Palaeoclimatol., 16:1-216.

Chase, T. E., Menard, H. W., and Mammerickx, J., 1971. Topography of the North Pacific: La Jolla (Univ. Calif.).

Dean, W. E., Gardner, J. V., Jansa, L. F., et al., 1978. Cyclic sedimentation along the continental margin of northwest Africa. In Lancelot, Y., Seibold, E., et al., Init. Repts. DSDP, 41: Washington (U.S. Govt. Printing Office), 965-989.

Dean, W. E., and Schreiber, B. C., 1978. Authigenic barite, Leg 41 Deep Sea Drilling Project. In Lancelot, Y., Seibold, E., et al., Init. 
Repts. DSDP, 41: Washington (U.S. Govt. Printing Office), 915931.

Firstbrook, P. L., Funnell, B. M., Hurley, A. M., et al., 1978. Paleoceanic Reconstructions, 160-0 Ma: Washington (National Science Foundation).

Fischer, A. G., Heezen, B. C., et al., Boyce, R. E., 1970. Geological history of the western North Pacific. Science, 168:1210-1214.

Hamilton, E. L., 1956. Sunken Islands of the Mid-Pacific Mountains. Geol. Soc. Am. Mem., 64.

Hardenbol, J., and Berggren, W. A., 1978. A new Paleogene numerical time scale. Am. Assoc. Petrol. Geol. Struct. Geol., 6:213-234.

Heezen, B. C., Fischer, A. G., et al., 1971. Site 44. In Fischer, A. G., Heezen, B. C., et al., Init. Repts. DSDP, 6: Washington (U.S. Govt. Printing Office), 17-39.

Heezen, B. C., Matthews, J. L., Catalano, R., et al., 1973. Western Pacific Guyots. In Heezen, B. C., MacGregor, I. D., et al., Init. Repts. DSDP, 20: Washington (U.S. Govt. Printing Office), 653-723.

Hilde, T. W. C., Uyeda, S., and Kroenke, L., 1976. Tectonic history of the western Pacific. In Drake, C. L. (Ed.), Geodynamics: Progress and Prospects: Washington (Am. Geophys. Union), pp. 1-15.

Jackson, E. D., and Schlanger, S. O., 1976. Regional syntheses, Line Islands chain, Tuamotu Islands chain, and Manihiki Plateau central Pacific Ocean. In Schlanger, S. O., Jackson, E. D., et al., Init. Repts. DSDP, 33: Washington (U.S. Govt. Printing Office), 915927.

Jenkyns, H. C., and Schlanger, S. O., 1981. Significance of plant remains in redeposited Aptian sediments, Hole 462A, Nauru Basin, to Cretaceous oceanic-oxygenation models. In Larson, R. L., Schlanger, S. O., et al., Init. Repts. DSDP, 61: Washington (U.S. Govt. Printing Office), 557-562.

Kennett, J. P., McBirney, A. R., and Thunell, R. C., 1977. Episodes of Cenozoic volcanism in the circum-Pacific region. J. Volcanol. Geothermal Res., 2:145-163.

Lancelot, Y., 1978. Relations entre evolution sedimentaire et tectonique de la plaque Pacifique depuis la Cretacée inferieur. Soc. Géol. France Mém. N.S., 134.

Lancelot, Y., and Larson, R. L., 1975. Sedimentary and tectonic evolution of the northwestern Pacific. In Larson, R. L., Moberly, R., et al., Init. Repts. DSDP, 32: Washington (U.S. Govt. Printing Office), 925-939.

Larson, R. L., 1976. Late Jurassic and Early Cretaceous evolution of the western central Pacific Ocean. J. Geomagnet. Geochem., 28:219-236.

Larson, R. L., Lancelot, Y., Gardner, J. V., et al., 1975. Magnetic, bathymetric, seismic reflection, and positioning data collected underway on Glomar Challenger, Leg 32. In Larson, R. L., Moberly, R., et al., Init. Repts. DSDP, 32: Washington (U.S. Govt. Printing Office), 393-427.

Larson, R. L., Moberly, R., et al., 1975. Site 313: Mid-Pacific Mountains. In Larson, R. L., Moberly, R., et al., Init. Repts. DSDP, 32: Washington (U.S. Govt. Printing Office), 313-390.

Lonsdale, P., Normark, W. R., and Newman, W. A., 1972. Sedimentation and erosion on Horizon Guyot. Geol. Soc. Am. Bull., 83: 289-316.

McCoy, F. W., and Zimmerman, H. B., 1977. A history of sediment lithofacies in the South Atlantic Ocean. In Supko, P. R., PerchNielsen, K., et al., Init. Repts. DSDP, 39: Washington (U.S. Govt. Printing Office), 1047-1079.

Marshall, M., 1975. Petrology and chemical composition of basaltic rocks recovered on Leg 32, Deep Sea Drilling Project. In Larson, R. L., Moberly, R., et al., Init. Repts. DSDP, 32: Washington (U.S. Govt. Printing Office), 563-570.

Matthews, J. L., Heezen, B. C., Catalano, R., et al., 1974. Cretaceous drowning of reefs on Mid-Pacific and Japanese Guyots. Science, $184: 462-464$.

Menard, H. W., 1964. Marine Geology of the Pacific: New York (McGraw Hill).

Moberly, R., and Larson, R. L., 1975. Mesozoic magnetic anomalies, oceanic plateaus, and seamount chain in the northwestern Pacific Ocean. In Larson, R. L., Moberly, R., et al., Init. Repts. DSDP, 32: Washington (U.S. Govt. Printing Office), 945-957.

Moore, T. C., van Andel, Tj. H., Sancetta, C., et al., 1978. Cenozoic hiatuses in pelagic sediments. Micropaleont., 24:113-138.

Natland, J. H., 1976. Petrology of volcanic rocks dredged from seamounts in the Line Islands. In Schlanger, S. O., Jackson, E. D., et al., Init. Repts. DSDP, 33: Washington (U.S. Govt. Printing Office), 749-777.

Rea, D. K., and Janecek, T. R., 1980. Grain-size and accumulation rate of the eolian component of some North Pacific sediments. Trans. Am. Geophys. Union, 61:257.

Rea, D. K., and Scheidegger, K. F., 1979. Eastern Pacific spreading rate fluctuation and its relation to Pacific area volcanic episodes. J. Volcanol. Geothermal Res., 5:135-148.

Rea, D. K., and Thiede, J., 1981. Mesozoic and Cenozoic mass-accumulation rates of the major sediment components in the Nauru Basin, western equatorial Pacific. In Larson, R. L., Schlanger, S. O., et al., Init. Repts. DSDP, 61: Washington (U.S. Govt. Printing Office), 549-556.

Reid, J. L., 1965. Intermediate Waters of the Pacific Ocean. Johns Hopkins Oceanogr. Stud., 2.

Schlanger, S. O., and Douglas, R. G., 1974. The pelagic ooze-chalklimestone transition and its implications for marine stratigraphy. Internat. Assoc. Sedimentol. Spec. Publ., 1:117-148.

Schlanger, S. O., Jackson, E. D., et al., 1976. Init. Repts. DSDP, 33: Washington (U.S. Govt. Printing Office).

Schlanger, S. O., Jenkyns, H. C., and Premoli Silva, I., 1981. Volcanism and vertical tectonics in the Pacific Basin related to global Cretaceous transgressions. Earth Planet. Sci. Lett., 52:435-449.

Schlanger, S. O., and Premoli Silva, I., 1981. Tectonic, volcanic, and paleogeographic implications of redeposited reef faunas of Late Cretaceous and Tertiary age from the Nauru Basin and the Line Islands. In Larson, R. L., Schlanger, S. O., et al., Init. Repts. DSDP, 61: Washington (U.S. Govt. Printing Office), 817-828.

Smith, A. G., and Briden, J. C., 1977. Mesozoic and Cenozoic Paleocontinental Maps: Cambridge (Cambridge Univ. Press).

Thiede, J., Dean, W. E., and Claypool, G. E., in press. Oxygen deficient depositional paleoenvironments in the mid-Cretaceous tropical and subtropical central Pacific Ocean. Cretaceous Res.

Thierstein, H. R., 1976. Mesozoic calcareous nannoplankton biostratigraphy of marine sediments. Mar. Micropaleont., 1:325-362.

1979. Paleoceanographic implications of organic carbon and carbonate distribution in Mesozoic deep-sea sediments. In Talwani, M., Hay, W., and Ryan, W. B. F. (Eds.), Deep Drilling Results in the Atlantic Ocean: Continental Margins and Paleoenvironment: Washington (Am. Geophys. Union), pp. 249-274.

Tissot, B., Durand, B., Espitelié, J., et al., 1974. Influence of the nature and diagenesis of organic matter in formation of petroleum. Am. Assoc. Petrol. Geol. Bull., 18:499-506.

Vail, P. R., Mitchum. R. M., Jr., and Thompson, S., 1977. Seismic stratigraphy and global changes of sea level, part 4: global cycles of relative changes of sea level. In Payton, C. E. (Ed.), Seismic Stratigraphy-Applications to Hydrocarbon Exploration: Am. Assoc. Petrol. Geol. Mem., 26:83-97.

Vallier, T. L., and Rea, D. K., 1980. Cretaceous volcanic episodes in the western Pacific Ocean: a synthesis of deep sea drilling results. Geol. Soc. Am. Abstr. Prog., 12:539.

van Andel, Tj. H., 1975. Mesozoic/Cenozoic calcite compensation depth and the global distribution of calcareous sediments. Earth Planet. Sci. Lett., 26:187-194.

van Andel, Tj. H., Heath, G. R., and Moore, T. C., 1975. Cenozoic history and paleoceanography of the central equatorial Pacific Ocean. Geol. Soc. Am. Mem., 143.

Van Couvering, J. A., and Berggren, W. A., 1977. The biostratigraphical basis of the Neogene time-scale. In Kauffman, E., and Hazel, J. E. (Eds.), New Concepts and Methods of Biostratigraphy: Stroudsburg (Dowden, Hutchenson, Ross), pp. 283-308.

van Hinte, J. E., 1976. A Cretaceous time scale. Am. Assoc. Petrol. Geol. Bull., 60:498-516.

Watts, A. B., Bodine, J. H., and Ribe, N. M., 1980. Observations of flexure and the geological evolution of the Pacific Ocean Basin. Nature, 283:532-537.

Winterer, E. L., 1976. Bathymetry and regional tectonic setting of the Line Islands Chain. In Schlanger, S. O., Jackson, E. D., et al., Init. Repts. DSDP, 33: Washington (U.S. Govt. Printing Office), 731-747.

Winterer, E. L., Ewing, J. I., et al., 1973. Site 171. In Winterer, E. L., Ewing, J. I., et al., Init. Repts. DSDP, 17: Washington (U.S. Govt. Printing Office), 283-334.

Worsley, T. R., and Davies, T. A., 1979. Sea level fluctuations and deep-sea sedimentation rates. Science, 203:455-456. 


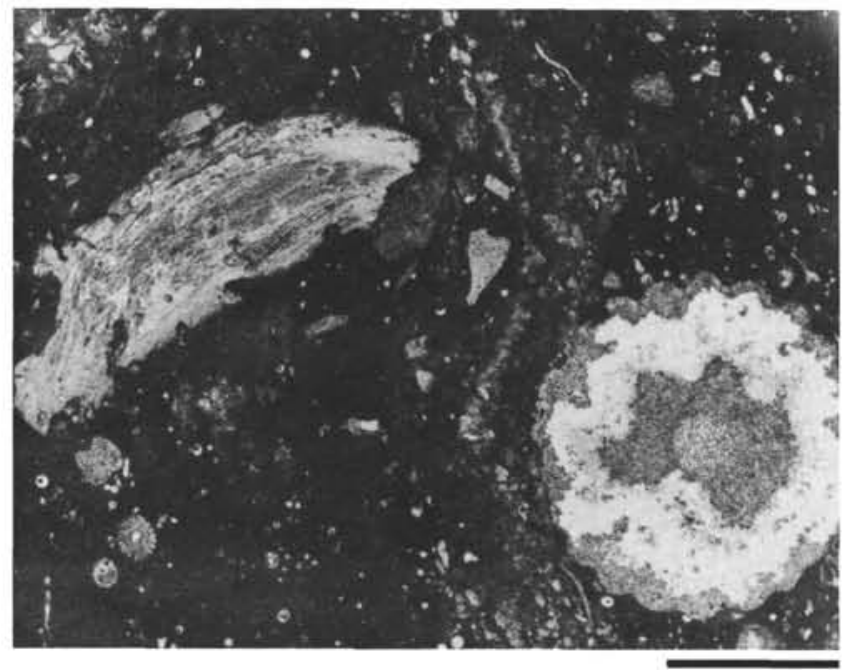

Figure 42. Sample 463-85-2, $130 \mathrm{~cm}$. Mollusk fragment (left) and echinoderm(?) fragment partly replaced by silica (right) in clastic limestone interbedded with pelagic limestone, Lithologic Unit IV. Plane light; $b a r=2 \mathrm{~mm}$.

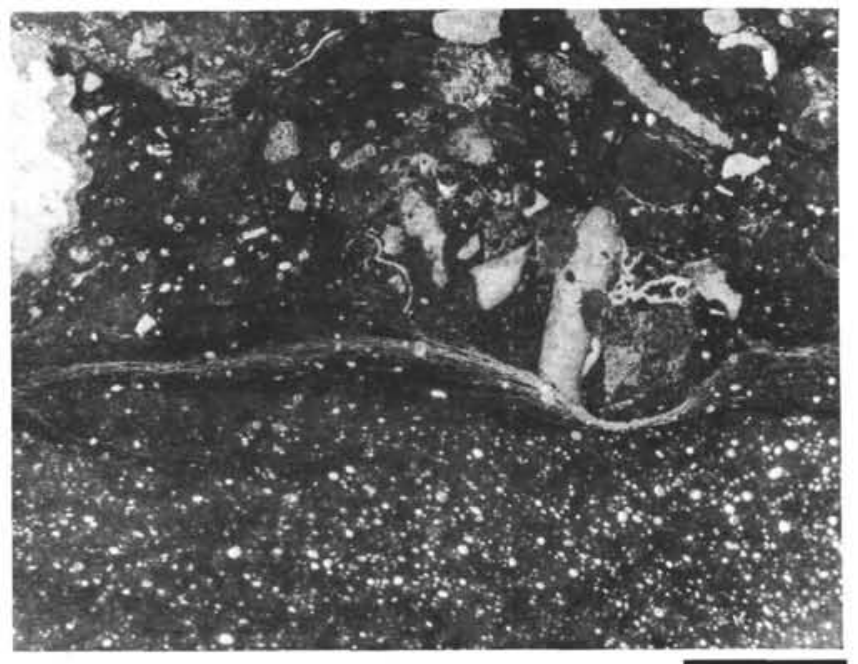

Figure 43. Sample $463-85-2,130 \mathrm{~cm}$. Contact between pelagic limestone (bottom) and clastic limestone (top), Lithologic Unit IV. Note wispy stylolitic seams distorted by clasts at the contact. Clasts are mostly of shallow-water carbonate debris and include oolites, fragments of oolitic and pelletal limestone, and fragments of echinoderms, large mollusks, and red algae(?). Plane light; bar $=2 \mathrm{~mm}$.

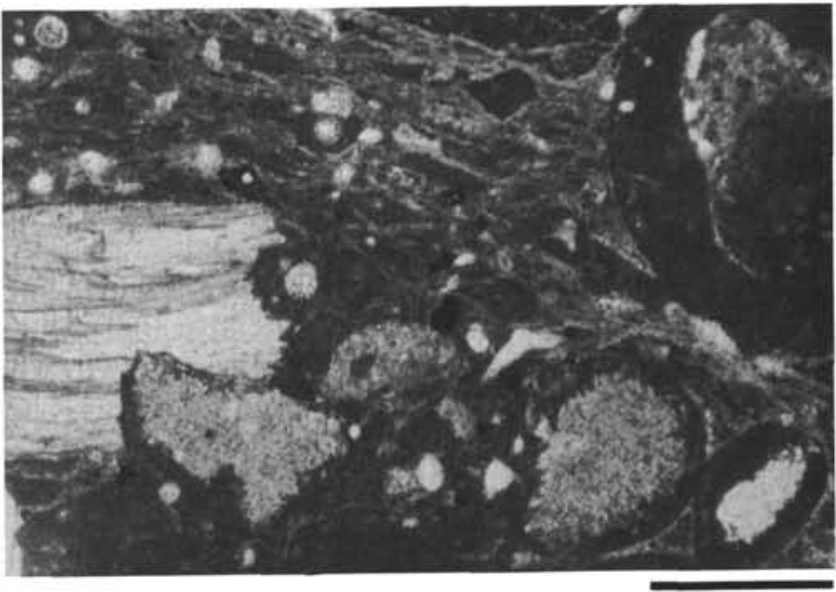

Figure 44 . Sample $463-85-2,130 \mathrm{~cm}$. Oolites, mollusk fragment, and other clasts distorting wispy stylolitic laminae at the contact between pelagic and clastic limestones, Lithologic Unit IV. Note interpenetration of grains. Cross-polarized light; $b a r=0.5 \mathrm{~mm}$.

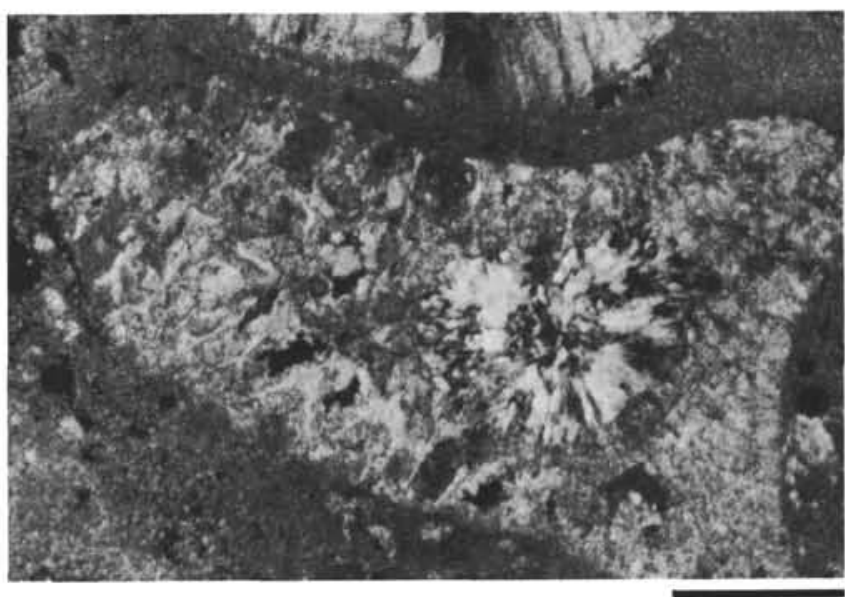

Figure 45 . Sample $463-85-1,138 \mathrm{~cm}$. Coral(?) fragment, partly replaced by silica. Cross-polarized light; bar $=0.5 \mathrm{~mm}$.

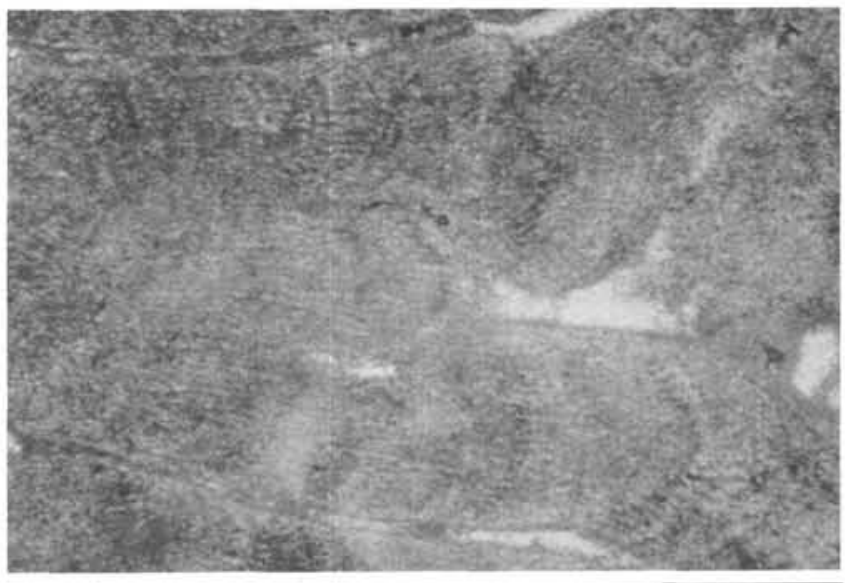

Figure 46. Sample 4563-85-2, $130 \mathrm{~cm}$. Fragment of calcareous red algae(?). Plane light; bar $=0.5 \mathrm{~mm}$. 


\section{J. THIEDE ET AL.}

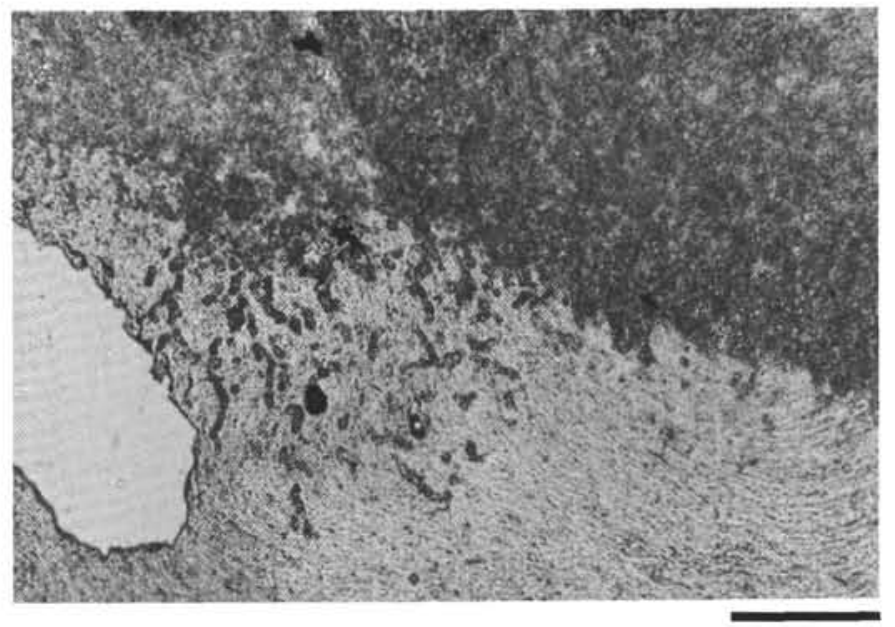

Figure 47. Sample 463-85-1, $138 \mathrm{~cm}$. Mollusk fragment (bottom) riddled by algal borings. Cross-polarized light; bar $=0.2 \mathrm{~mm}$.

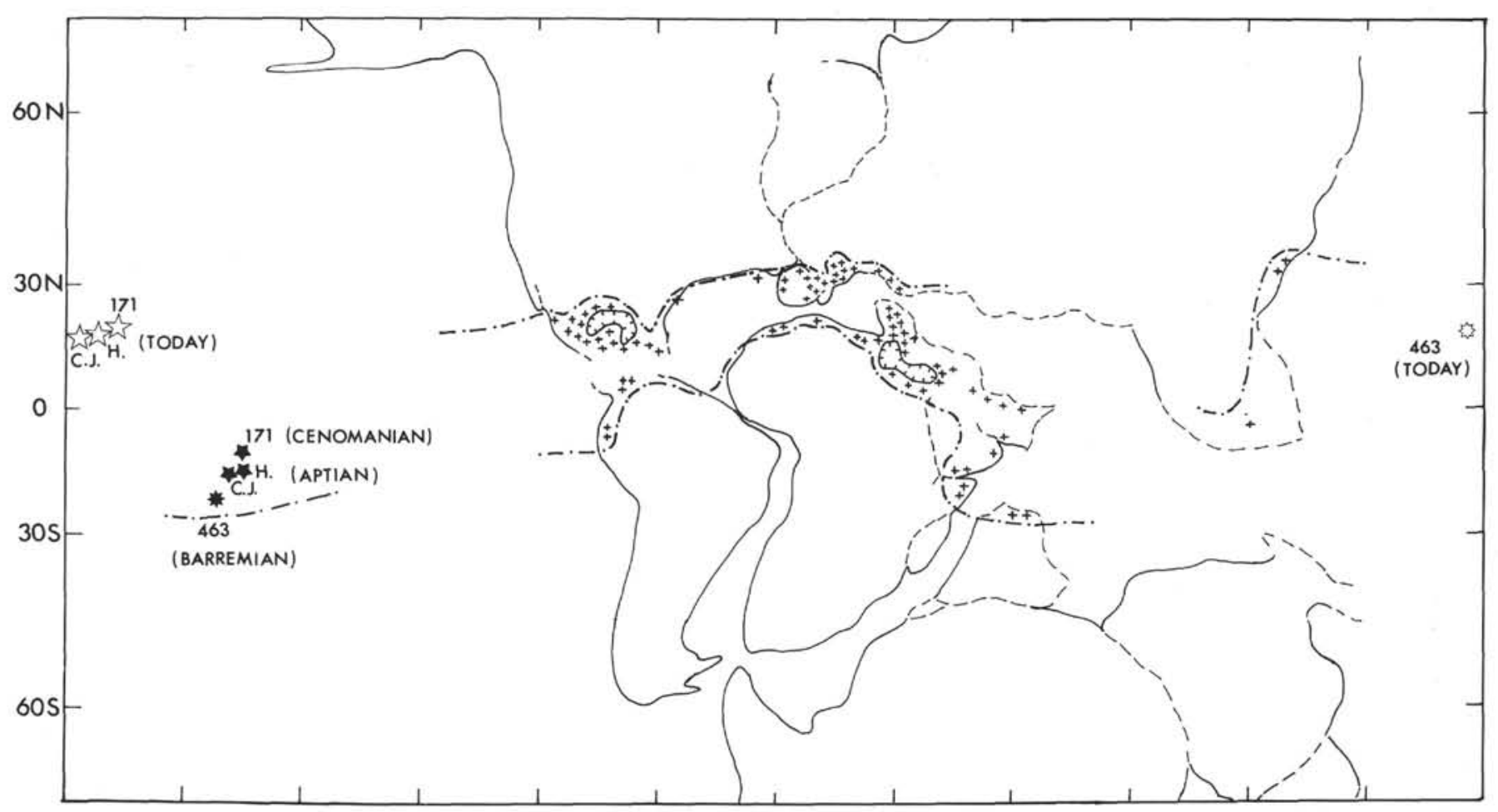

Figure 48. Global distribution of thick Lower Cretaceous rudistid-bearing carbonate sequences (crosses) in the "Urgonian belt" from many sources (see also review in Arthur and Schlanger, 1979). The Mid-Pacific Mountains guyots have been back-tracked according to Lancelot and Larson's (1975) hypothesis of an average northwesterly motion of the old Pacific Plate throughout its history. Paleocontinental map from Smith and Briden (1977). DSDP sites are numbered, Horizon and Cape Johnson guyots indicated by letters (from Ferry and Schaaf, this volume). 